\title{
ASSESSMENT OF RESEARCH NEEDS FOR \\ COAL UTILIZATION
}

DOE COAL COMBUSTION AND APPLICATIONS WORKING GROUP

(CCAWG)

Submitted by: S. S. Penner, Chairman of CCAWG

Energy Center and Department of Applied

Mechanics and Engineering Sciences

University of California, San Diego

La Jolla, California 92093

August 1983

Contract Sponsors: DOE Office of Energy Research and Fossil Energy. DOE Program Managers: Dr. Jorgen Birkeland, Mr. John Kaufmann, Dr. G. Jordy, Dr. R. Roberts. DOE Contract Number: DOE DE-FG03-82FE-60014. 


\section{DISCLAIMER}

This report was prepared as an account of work sponsored by an agency of the United States Government. Neither the United States Government nor any agency thereof, nor any of their employees, make any warranty, express or implied, or assumes any legal liability or responsibility for the accuracy, completeness, or usefulness of any information, apparatus, product, or process disclosed, or represents that its use would not infringe privately owned rights. Reference herein to any specific commercial product, process, or service by trade name, trademark, manufacturer, or otherwise does not necessarily constitute or imply its endorsement, recommendation, or favoring by the United States Government or any agency thereof. The views and opinions of authors expressed herein do not necessarily state or reflect those of the United States Government or any agency thereof. 


\section{DISCLAIMER}

Portions of this document may be illegible in electronic image products. Images are produced from the best available original document. 


\section{ABSTRACT}

The Coal Combustion and Applications Working Group (CCAWG), at the request of J. W. Mares (Assistant Secretary for Fossil Energy) and A. W. Trivelpiece (Director, Office of Energy Research), has reviewed and evaluated the U.S. programs on coal combustion and utilization. The important topical areas of coal gasification and coal liquefaction have been deliberately excluded because Rog $D$ needs for these technologies were reviewed previously by the DOE Fossil Energy Research Working Group. The CCAWG studies were performed in order to provide an independent assessment of research areas that affect prospects for augmented coal utilization. In this report, we summarize the findings and research recommendations of CCAWG. 
Dr. Seymour B. Alpert

Technical Director (alternate member with $K$. Yeager)

Advanced Power Systems Division Electric Power Research Institute P.O. Box 10412

Palo Alto, California 94303

(415) 855-2512

Professor János M. Beér

Department of Chemical Engineering Room 66-552

Massachusetts Institute of Technology Cambridge, Massachusetts 02139

(617) 253-6661

Mr. Carl R. Bozzuto, Director (alternate member with R. B. Knust)

Advanced Systems \& Technologies

Fossil Power Systems

C-E Power Systems

Combustion Engineering, Inc.

Windsor, Connecticut 06095

(203) 688-1911 ext. 3571

Professor Irvin Glassman

School of Engineering/Applied Science

Center for Environmental Studies

The Engineering Quadrangle

Princeton University

Princeton, New Jersey 08540

(609) 452-5199

Mr. Ronald B. Knust, Vice Fresident

(alternate member with C. R. Bozzuto)

Research \& Development, 9002-428

Combustion Engineering

1000 Prospect Hill Road

Windsor, Connecticut 06095

(203) 688-1911 ext. 2396

Mr. Wallace Markert, Jr., Vice President

(alternate member with $C$. L. Wagoner)

Research \& Development Division

Babcock and Wilcox

P.O. Box 835

Alliance, Ohio 44601

(216) $821-9110$ ext. 600

Professor Antoni K. Oppenheim

Mechanical Engineering

College of Engineering

University of California

Berkeley, California 94720

(4I5) 642-6000 ext. 0211
Professor S. S. Penner (CCAWG Chairman)

Director, Energy Center, B-010

University of California, San Diego

La Jolla, California 92093

(714) 452-4284

Dr. L. Douglas Smoot, Dean

College of Engineering and Technology

Brigham Young University

$270 \mathrm{CB}$

Provo, Utah 84602

(801) $378-4326$

Mr. Robert E. Sommerlad, Vice President

(alternate nember with $W$. Wolowodiuk)

Contract Operations Division

John Blizard Research Center

Foster Wheeler Development Corporation

12 Peach Tree Hill Road

Livingston, New Jersey 07039

(201) $533-3650$

Mr. Charles L. Wagoner, Technical Advisor (alternate member with W. Markert, Jr.) Fuels

Babcock and Wilcox

Alliance Research Center

P.O. Box 835

Alliance, Ohio 44601

(216) $821-9110$

Dr. Irving Wender

Department of Chemical Engineering

1249 Benedum Hall

University of Pittsburgh

Pittsburgh, Pennsylvania 15261

(412) 624-5281

Mr. Walter Wolowodiuk, Vice President

(alternate member with R. E. Somnerlad)

Research and Development

John Blizard Research Center

Foster Wheeler Development Corporation

12 Peach Tree Hill Road

Livingston, New Jersey 07039

(201) 533-3639

Mr. Kurt Yeager, Director

(alternate member with S.B. Alpert)

Coal Combustion Systems Division

Electric Power Research Institute

P.0. Box 10412

Palo Alto, California 94303

(415) $855-2456$ 
Dr. Jorgen Birkeland

Office of Coal Research

Office of Fossil Energy

20 Massachusetts Avenue, Room 124

U.S. Department of Energy

Washington, D.C. 20545

(301) 353-4718

Dr. Charles Garrett

Manager, AR\&TD

Direct Utilization Program, FE-14

U.S. Department of Energy

Washington, D.C. 20545

(301) 353-2786

Dr. George Y. Jordy

Associate Director for Program Analysis

Office of Energy Research

U.S. Department of Energy

Washington, D.C. 20545

(301) 353-2971

Mr. John F. Kaufmann

Deputy Associate Director for Program Analysis

Office of Energy Research, Al-4000

U.S. Department of Energy

Washington, D.C. 20545

(301) 353-2951

Dr. Robert Roberts

Acting Director for Advanced Research and

Technology

Office of Fossil Energy

FE-60 C-171, GTN

U.S. Department of Energy

Washington, D.C. 20545

(301) $353-2786$ 


\section{FOREWORD}

The members of the DOE Coal Combustion and Applications Working Group (CCAWG) performed an extensive series of site visits to industrial, governmental and university laboratories in order to familiarize themselves with current and planned research programs. Site-visit reports and evaluations, with emphasis on identified process and fundamental research needs, were prepared by participating CCAWG members after each site visit. These site-visit reports are reproduced in Appendix B.

In addition, CCAWG received written comments on a preliminary version of this report in response to the transmittal letter that is reproduced in Appendix A.

The Executive Summary is followed by an introductory discussion (Chapter 1) in which we present the CCAWG study objectives, describe operating features of selected coal combustion and application processes, and summarize research recommendations derived from our site-visit evaluations. Our detailed research recommendations are discussed in Chapters 2 to 7.

Cost evaluations and market penetration of new technologies have formed integral components of our deliberations and references to these problem areas will be found in connection with each of the process technologies which we discuss.

Our research recommendations cover a wide spectrum of activities in the areas of coal combustion and coal utilization, ranging from fundamental science to process engineering. They have not been constructed to satisfy the primary goals of either the scientist or the development engineer. Adequate research support for programs relating to coal combustion and applications may aid commercial implementation of the right technologies over the long term and may also be of value in the definition and identification of new or different technologies that merit commercialization.

The members of CCAWG acknowledge with thanks the advice and assistance provided by many individuals in government, industry and the universities. The following people, among others, have contributed to our discussions, evaluations, and final recommendations: D. Anson (Battelle/Columbus); T. Armor (EPRI); R. Bergemann (DOE); D. Bienstock (DOE/PETC); J. C. Blanton (GE); R. Bryers (Foster Wheeler); K. Castleton (DOE/METC); F. Crouse (DOE/ METC); S. Dalton (EPRI); S. Drenker (EPRI); V. S. Engleman (Science Applications); W. French (DOE/METC); H. Fruh (Foster Wheeler); R. L. Gamble (Foster Wheeler); R. Cannon (AVCO); L. Graham (DOE/METC); A. Ha11 (DOE/METC); J. Hal1 (DOE/METC); J. Halow (DOE/METC); 
C. Harrison (EPRI); L. Headley (DOE/METC); M. A. Heap (Energy and Environmental Research Corp.); M. Hertzberg (DOE/PETC); M. L. Jones (DOE/GFETC); R. Kessler (AVCO); P. G. Kosky (GE); R. Kurtzrock (DOE/ PETC); M. Lapp (GE); N. J. Lipstein (GE); I. Lutes (Foster Wheeler); R. Manfred (EPRI); K. Markel (DOE/METC); J. Maulbetch (EPRI); D. H. Maylotte (GE); M. McElroy (EPRI); R. A. Meyers (TRW); E. Michaud (Babock \& Wilcox); S. Moskowitz (Curtiss-Wright Corp.); H. Nack (Battelle/Columbus); J. Notestein (DOE/METC); R. Patrick (AVCO); A. Pitrolo (DOE/METC); G. Preston (EPRI); A. Robertson (Foster Wheeler); F. Rourke (Foster Wheeler); J. Y. Shang (DOE/METC); V. Shui (AVCO); S. P. N. Singh (ORNL); D. P. Smith (GE); A. Solbes (TRW); D. B. Stickler (AVCO); D. Swallom (AVCO); T. Tyson (Energy and Environmental Research Corp.); C. von Rosenberg (AVCO); D. Waltermire (DOE/METC); J. Williams (DOE/METC); J. S. Wilson (DOE/METC); and V. Zakkay (New York University).

We have examined in some depth each of the following technologies: use of coal slurries (coal-water, coal-oil, and other coalliquid mixtures) for retrofitting oil burners and applications in new units, developments of improved pulverized coal burners, atmospheric fluidized bed combustors, pressurized fluidized bed combustors, coal beneficiation. Familiarity with developing coal-utilization technologies was gained from personal programmatic involvements, as well as from numerous site visits and discussions (see Appendix B for detailed descriptions of these activities). This report has been prepared in three parts as follows: (i) a lengthy and essentially unedited summary of our site visit reports, including presentations made to us (Appendix B); (ii) a tutorial summary of our findings derived from the site visits, including research recommendations made by others to us (Chapter 1); (iii) our own recommendations prepared, for the most part, as additions to what we learned from others (Chapter 2). An abbreviated version of our studies, written for publication in the archival literature, is submitted together with this report. 
LIST OF ILLUSTRATIONS

LIST OF TABLES

EXECUTIVE SUMMARY

NOMENCLATURE

CHAPTER 1 INTRODUCTION TO COAL COMBUSTION AND APPLICATIONS TECHNOLOGIES

1.1 Direct Coal Utilization in Pulverized-Coal Combustors (PCCs)

1.1A DOE Supporting Research

1.1B Costs for Large Coal-Fired, Nuclear and 0i1xvii

1.1C Market Penetration

1.1D Relations Between Coal Quality, Boiler Availability and Power Costs

1.1E Some New Commercial Designs

1.1F Coal Preparation and On-Site Coal Handing for PCCs

1.1G Research on Coal Combustion

$\begin{array}{lll}1.2 & \text { Coal SIurries } & 17\end{array}$

1.2A COM

1. $2 \mathrm{~B} \quad \mathrm{CWM}$

1.2C CMM

1.2D Market Penetration of Coal Slurries 20

1.2E Combustion R\&D Status of COM 21

1.2F Combustion RED Status of CWM

1.2G Cost Analysis of the Application of Coal-Water Mixtures (CWM) to Gas-Turbine Firing

1.3 Atmospheric-Pressure Fluidized-Bed Combustors (AFBCs) 34

1.3A Commercial and Prototype Developments of AFBCs 34

1.3B Preliminary Identification of R\&D Needs 44

1.4 Pressurized Fluidized Bed Combustors (PFBCs) 47

1.4A Past and Current Developments 47

1.4B R\&D Recommendations on PFBCS 50

1.5 Advanced (Developing) Coal-Combustor Designs and Coal-Combustion Applications

1.5A The Battelle Multisolids Fluidized Bed Combustor (MSFBC)

1.5B Slagging Combustors

1.5C Gas-Turbine Applications 


\section{TABLE OF CONTENTS (Continued)}

$\underline{\text { Page }}$

1.5D Integrated Coal Gasification Gas Turbine Combined Cycle (IGCC) System

57

60

Coal Quality and Clean-Up

60

1.6A Analyses and Diagnostics

1.6B Coal Beneficiation

1.7 Fouling and Slagging

I.8 Coal-Plant Safety; Flammability of Coal-dust-Air Mixtures

$1.8 \mathrm{~A}$ Oxidation and Heating of Coals

1.8B Flammability of Coal-Dust-Air Mixtures

1.9 Environmental Concerns, Regulations and Studies 77

1.9A The EPRI Program

1.9B Particulate Clean-Up

1.9C Novel Developing Control Technologies

References

CHAPTER 2 RED RECOMMENDATIONS RELATING TO DIRECT COAL UTILIZATION

2.1 Costing and Commercialization

2.1.1 Overview

2.1.2 Research Recommendations

2.2 Coal Preparation

2.2.1 Overview

2.2.2 Research Recommendations

2.3 Safety in Coal Utilization, Comminution and Feeding 100

2.3 .1 Overview

2.3.2 Research Recommendations

100

105

$2.4 \quad$ Fouling and Slagging $\quad 106$

2.4 .1 Overview 106

2.4.2 Near-Term Research Recommendations 108

2.4.3 Long-Term Research Recommendations 108 
2.5 PC Boilers

2.5 .1 Overview

2.5.2 Research Recommendations

2.6 Atmospheric Fluidized Bed (AFB) Combustion

2.6.1 Overview

2.6.2 Research Recommendations

2.7 Advanced Atmospheric and Pressurized Fluidized Bed

115 (PFB) Combustion

2.7 .1 Overview

2.7.2 Research Recommendations

2.8 Coal-0il Mixtures (COM)

2.8.1 Overview

2.8.2 Research Recommendations

116

121

2.9 Coal-Water Mixtures (CWM) 122

2.9.1 Overview

2.9.2 Research Recommendations

2.10 Status and Needs for Mathematical Modeling of Coal-Combustion Processes

2.10.1 Overview

132

2.10.2 Research Recommendations

139

2.11 Environmental Issues 142

2.11.1 Overview

2.11.2 Research Recommendations

142

143

$\begin{array}{lll}2.12 & \text { Utility Perspectives } & 147\end{array}$

2.12 .1 Overview 147

2.12.2 Research Recommendations 150

APPENDIX A: STATEMENT OF WORK 153 


\section{LIST OF ILLUSTRATIONS}

Figure Number

$\underline{\text { Page }}$

1.1-1 Past and estimated future utilization of coal and lignite in the utility, industrial and residential-commercial sectors

$1.1-2$

A plot plan for a typical, large, coal-fired power plant

1.1-3 Schematic diagram showing the principal components of a utility unit burning pulverized coals

$1.1-4$

Schematic diagram of a commercial boiler (Foster wheeler Corp.) for the direct combustion of pulverized lignite and other fuels 14

$1.3-1$

Schematic diagram showing changes in the geometrical designs of coal-fired power plants from stoker to pulverized coal burner to fluidized-bed combustor

$1.3-2$

Georgetown University steam generator (12.6 $\mathrm{kg} / \mathrm{s}=100,000 \mathrm{lb} / \mathrm{hr}$ ) using $\mathrm{AFBC}$

$1.3-3$

City of Eksjo (Sweden) hot-water generator, which normally burns municipal refuse and wood chips in a fluidized bed of sand at an output of $5 \mathrm{MW}_{t}$

$1.3-4$

Royal Dutch Shell (Netherlands) steam generator built by the Foster Wheeler Corporation with startup in 1982

$1 \cdot 3-5$

Idaho National Energy Laboratory saturated steam generator $[8.5 \mathrm{~kg} / \mathrm{s}=67,500 \mathrm{1b} / \mathrm{hr})]$ for heating a nuclear fuel-processing faci1ity (startup is planned for 1984)

$1.3-6$

Schematic diagram of the proposed $20 \mathrm{MW}_{\mathrm{e}}$ EPRI AFBC

$1.3-7$

$1.3-8$

1. $4-1$

1. $5-1$

Flow diagram for the $20^{\prime \prime} \times 20^{\prime \prime}$ Foster wheeler fluidized bed pilot plant

Enhancement of limestone sulfation by hydration

Schematic diagram of a combined cycle PFBC

The Battelle multisolid fluidized-bed combustor, depicted in three operating modes

1. $5-2$

Schematic diagram showing operational components of the Battelle multisolid fluidizedbed combustor

Schematic diagram showing the combustion-

$1.5-3$ chamber design used in the AVCO-Everett slagging combustor for MHD power generation

$1 \cdot 5-4$

Schematic diagram showing operation of a gas turbine with high-ash resids 
$1.5-5$

$1.7-1$

$1.7-2$

$1.7-3$

$1.7-4$

1. $9-1$

$1.9-2$

$2.3-1$

$2.4-1$

$2.9-1$

$2.9-2$

$2 \cdot 10-1$
Schematic diagram of the Westinghouse integrated coal-gasification, combinedcycle system

Percentages of potential electricity-generation capacity lost for Western coals because of slagging and fouling.

overview of some factors affecting slagging and fouling

Schematic diagram of a system for combustion studies of solid-liquid mixtures

Conceptual drawing of the test section used for sooting-deposition studies

The AVCO/Ebara combined $\mathrm{SO}_{\mathrm{X}}, \mathrm{NO}_{\mathrm{X}}$ and particulate-removal system

Schematic diagram suggesting the method of application of ASPEN in process control and modeling

Threshold between safe and hazardous regimes in terms of rate and amount of energy deposition in an exploding medium

Slag deposits formed in a sub-scale pulverized fuel combustion test

EPRI projections of production rate and cost of CWM

Carbon conversion data for CWM

128

Aspects of a pulverized coal combustor 


\section{LIST OF TABLES}

Table Number

$\underline{\text { Page }}$

1.1-1 Capital costs for a typical, large, coa1-

$1.1-2$ fired plant

1. $2-1$

Costs in mills/kWe-hr for various fuels

Cost comparisons between conventional and CFCC plants

$1.4-1$

A summary of identified research needs relating to PFBCs

1. $5-1$

Deposit formation ratios observed in simulation tests with number 2 fuel oil containing dopants

$1.6-1$

Comparison of the material recoveries and beneficiation costs for the five conceptual coal beneficiation processes (secondquarter 1978 costs)

$1.7-1$

GFERC research recommendations on 1 ow-rank coals (LRC) of "highest priority"

$1.7-2$ GFERC research recommendations on LRC of "lower priority"

$1.9-1$

1. $9-2$

$1.9-3$

$1.9-4$

EPRI environmental assessment program (as of September 1982) with proposed budgets in millions of dollars) for 1983-1987

Summary of DOE/METC particulate contro1 techniques under development during 1982

performance estimates for percentage removals of $\mathrm{SO}_{\mathrm{X}}$ and $\mathrm{NO}_{\mathrm{X}}$ using the AVCO/Ebara E-beam scrubber

Cost comparison between the limestone scrubber and the AVCO/Ebara E-beam dry scrubber

$2.1-1$

Introduction schedules for selected energy technologies

2.3-1 Processes pertaining to hazardous combustion phenomena

2.8-1 Estimated market potential (utility boilers $>50$ MW with 0.50 capacity factor and $50 \%$ market penetration; industrial boilers $>100 \times 10^{3} \mathrm{MJ}-\mathrm{hr}^{-1}$ with 0.35 capacity factor and market penetrations of $50 \%$ for coal-designed equipment, $25 \%$ for oil-de. signed boilers, and 50\% for blast furnaces) 117

$2.8-2$ COM system characteristics and operating experience 
2.9-1 Estimated FY 1983 U.S. R\&D expenditures on coal-water mixtures

$2.9-2$ Estimated identified 1983 CWM R\&D in the U.S.

124

$2.10-1$

$2.10-2$

A classification system for coal models Examples of current U.S. modeling on pulverized coal combustion 


\section{EXECUTIVE SUMMARY}

Appreciable levels of market penetration for new coalutilization technologies have generally required 40-50 years after laboratory research commenced. Useful innovations have been introduced by the private sector with deliberate despatch while operating under market conditions. It is difficult to accelerate this natural progression from invention to laboratory studies, to pilot-plant testing, to demonstration and, finally, to commercialization.

\section{A. Combustion Research}

We have prepared neither prioritized listings of our. research recommendations (cf. Chapter 2) nor of budgetary requirements. It is, however, apparent to us that available funding for fundamental generic research in coal combustion and applications is far below desirable levels in view of the scale of the field, its importance to U.S. energy supplies, the number of competent people who could and should contribute, and its importance to maintaining U.S. technology at the cutting edge of international competition. Current funding in the U.S. for fundamental generic research, as distinct from research directed at particular applications and problem solving, is probably less than $\$ 10 \times 10^{6}$ per annum, counting both private sector and governmental support. In the view of some of our members, a five-fold augmentation of existing budgetary support would be an appropriate near-term goal over a three-year period.

Our evaluations suggest that fundamental research leading to improved understanding is likely to be of near-term 
practical utility, especially in the following three areas:

- Research should be done to define the relations between coal compositions, coal beneficiations and combustion behavior.

- Fundamental studies are needed to elucidate the mechanisms and rate processes involved in fouling, slagging, erosion, and unit reliability. These mechanisms and rates should be related to coal composition (including mineral contents) and combustion processes.

- Development of combustion models is needed to the point where they will find wide application in the management and control of practical systems. This ambitious goal can probably be achieved only with greatly improved understanding of the fluid dynamic and chemical processes occurring in coal combustors, utilization of improved diagnostic techniques in model verification, and evolutionary improvements in the combustion models themselves.

The preceding listing should not be interpreted to imply that we view continuing research in other fields to be of lesser importance over the long term. Fundamental research is certain1y justified in each of the following areas: thermal decomposition mechanisms (pyrolysis) of coals, mechanisms and kinetics of coal-char oxidation, combustion of volatiles formed from coals, mechanisms and rates of soot formation and oxidation, fuel-nitrogen evaluation and conversion, quantitative descriptions of radiative heat transfer in multi-phase media of the type encountered in coal burning, fundamental studies on each of 
the many processes that is involved in systems modeling of coal-utilization equipment, dynamics of turbulent flow carrying particles and/or droplets, etc. We also recognize that the greatest long-term contributions are likely to be realized from the results of studies performed by scientists and engineers working without undue constraints and supported over the long term on topics and applications that we cannot foresee.

\section{B. Environmental Studies}

- The DOE has a special and significant role to perform in advancing basic understanding of processes and mechanisms that play important roles in pollutant formation, removal, and output. This programme should properly encompass the entire range of activities beginning with coal preparation, coal beneficiation, additives, combustiondesign modifications, post-combustion clean-up, and disposal of ash and other materials.

\section{Pilot and Demonstration Programs}

These programs are the most expensive and the most controversial programs in R\&D. Historically, they have been carried out in an evolutionary manner in the power industry. This approach focuses first on small-size units with relatively low cost and low risk, which is then followed by scale up to larger units. Commercial implementations require a considerable length of time. Because the utility sector is the largest user of coal and utilizes large-scale plants, attempts have been made in the past to accelerate the development process by eliminating some of the intermediate steps. These accelerations have not generally 
been successful.

The Federal Government can take a constructive role in aiding the introduction of new technology in the power industry. Direct, contributory support (money) is not the only device or even the preferred means for aiding commercialization. We believe that the following policies will be required in order for the U.S. to maintain a leadership position in energy technology relative to foreign competitors:

- A stable and non-adversary relationship must be established between the government and industry.

- Low inflation and a monetary policy maintaining low interest rates are highly desirable.

- Stable, long-term economic growth provides the best background for innovation.

- Lower marginal tax rates, especially for investment and R\&D expenditures, are conducive to high-risk developments.

Implementation of the specified policies will provide incentives to industry to develop new technologies without the need for major government infusions of money. Because of the long time frames involved in the creation of new designs for the power industry, stable policies, stable prices, and stable growth are more important for successful commercialization of new technologies than massive federal programs for the construction of demonstration plants. 
NOMENCLATURE

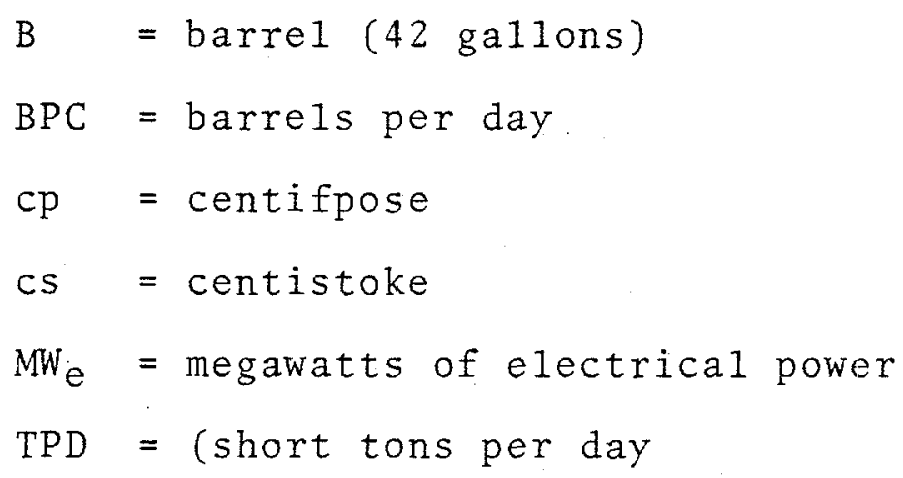


CHAPTER 1

\section{INTRODUCTION TO COAL COMBUSTION AND} APPLICATIONS TECHNOLOGIES

Coal is the world's most plentiful fuel. Increased use of coal can be anticipated throughout this century, particularly in the electric utility industry, which is the largest user of coal. Over $55 \%$ of U.S. electricity was generated from coal in 1981. Current developments point to innovative applications to generate steam and electricity under environmentally acceptable constraints, as we11 as to improvements in conventional techniques. Promising new techniques include the utilization of coal slurries in place of oil in utility and industrial boilers, the development of improved atmospheric and pressurized fluidized bed combustors, the designs of integrated combined cycle systems (e.g., for utility applications), as well as coal-gasification and liquefaction for the purpose of augmenting supplies of natural gas and liquid fuels, respectively.

Coal deposits are abundant throughout the world. Coal classifications by rank define weight percent of carbon and energy release on combustion, while elemental analyses include trace-element concentrations. Using 1978 technology, world-wide coal reserves were estimated to be about $17,700 \times 10^{15}$ Btu or $3.04 \times 10^{12} \mathrm{bbl}$ of oil equivalent with the following country and regional shares: USA, 28\%; Europe, 20\%; USSR, 17\%; China, 16\%; other Asian countries, 6.3\%; Africa, 5.4\%; Oceania, $4.3 \%$; South America, 1.7\%; Canada, $1.5 \%$.

Coal production has been increasing through the world since the oil embargo of 1974 and this trend is expected to accelerate when improved utilization schemes become commercially viable activities. Thus, U.S. coal production, which grew from $620 \mathrm{x}$ $10^{6}$ tons in 1970 to $830 \times 10^{6}$ tons in 1980 , could conceivably be

\footnotetext{
"W. Peters and H. D. Schilling, "An Appraisal of World Energy Resources and Their Future Availability," 1978 World Energy Conference; R. I. Loftness, Energy Handbook, Van Nostrand Reinhold Co., New York, 1978.
} 
doubled by the end of the twentieth century. Large-scale coal applications have remained mostly confined to electric power generation and industrial boilers using direct combustion of pulverized coals. A small percentage of the coal has been traditionally used for steel production.

In this chapter, we restrict consideration to topical areas that appear especially promising for expanded coal utilization using improved technologies. This background material should be viewed as an introduction to the corresponding R\&D recommendations presented in succeeding chapters.

1.1 Direct Coal Utilization in Pulverized-Coal Combustors (PCCs)

The direct use of pulverized coal in industrial and utility boilers represents established commercial operations that account for nearly the total utilization of mined coal in all parts of the globe. Coal burning in the residential-commercial sector has traditionally represented only a few percent of total use and is unlikely to grow relatively rapidly because of the high costs of installing adequate control technologies on very small units. A representative (1977) retrospective and prospective view of coal applications is summarized in Fig. 1.1-1, which has been reproduced from a 1977 OTA report.

In contrast to stokers, which use lumps of coal supported on a travelling grate, or fluidized combustion in which crushed coal is burned, pulverized coal combustion (PCC) involves the burning of a finely ground (mean particle size $\sim 50 \mu \mathrm{m}$ ) cloud of particles in an entrained flow. Following ignition, the coal burns under steadystate conditions at temperatures of about $2000 \mathrm{~K}$. In industrial and utility boilers, these high-temperature gases are used to generate steam by predominantly radiant heat transfer to steam generating tubes which cover the walls of the large "radiant" combustion chambers. It is expected that PCC technology will provide most of the new generating technology to the year 2000 . 


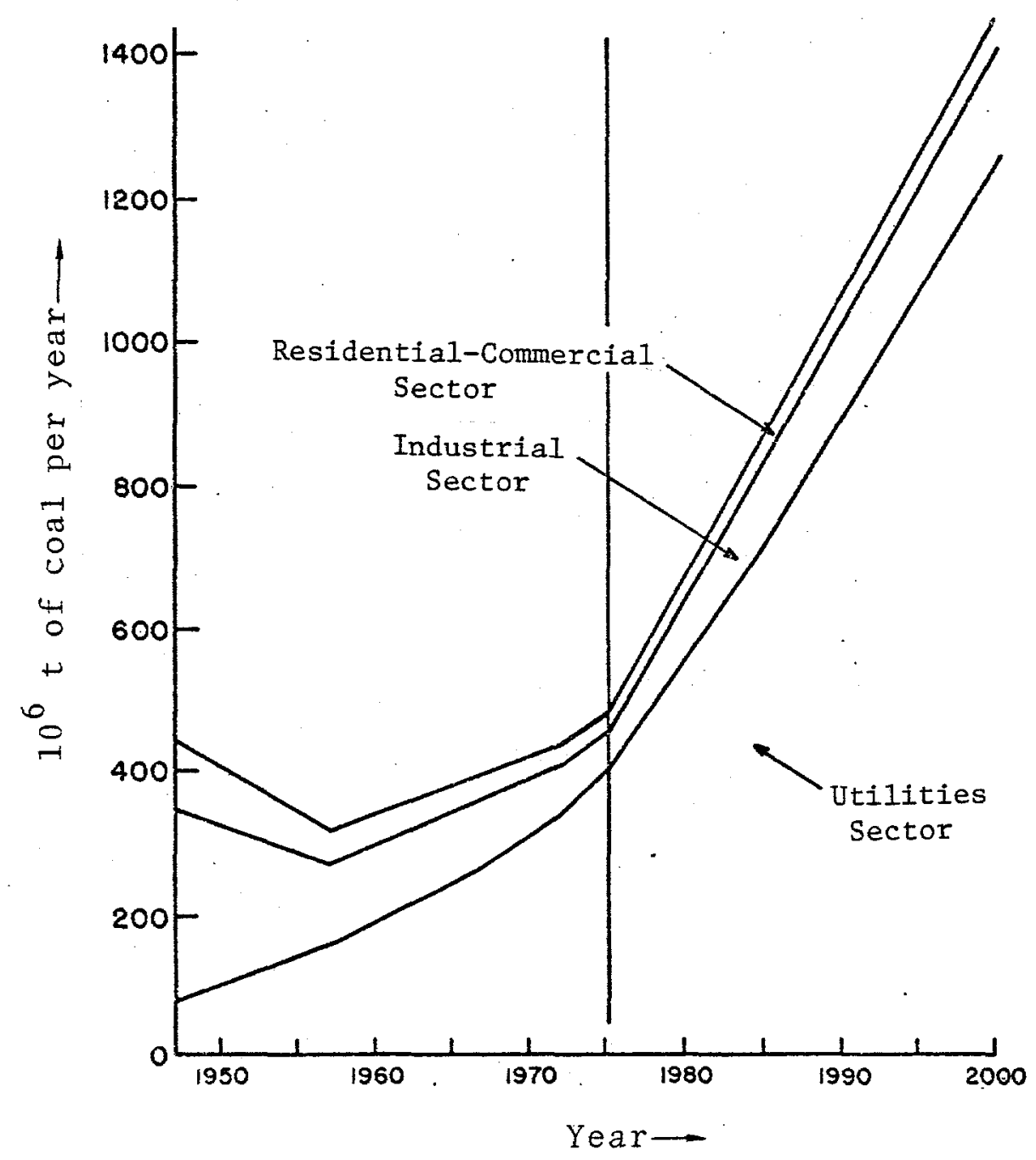

Fig. 1.1-1 Past and estimated future utilization of coal and lignite in the utility, industrial and residentialcommercial sectors; reproduced from the "Annual

Report to Congress," Energy Information Administration, Department of Energy, OTA, Vol. III, 1977. 


\subsection{A DOE Supporting Research}

DOE-supported studies dealing with fundamental research on pulverized coal combustion are reviewed at annual contractors' meetings. The 1982 review $^{1}$ shows work designed to elucidate the following: elementary processes involved in devolatilization and combustion of coal particles; the influence of particulate loading on flow; studies of preignition; influence of heating rates and early combustion on the production of nitrogen and sulfur compounds; staged combustion to reduce $\mathrm{NO}_{\mathrm{X}}$ output and, with the addition of $\mathrm{CaO}$, to remove sulfur; the effects of mineral matter on slag deposition; ash fouling produced by low-rank coals; characterization of deposits; combustor modeling and scaling; combustor modifications and acoustically-induced mixing to control $\mathrm{NO}_{\mathrm{X}}$ emissions; fundamental studies on coal-water mixtures (CWM) to define flow properties, rheology, and atomization. Studies of this type have a bearing on all coal-utilization techniques since they deal with properties which will play a role not only in the direct utilization of PCCs but in other current or proposed applications as well.

\section{IB Costs for Large Coal-Fired, Nuclear and Oil-Fired}

A plot plan of a typical, large, coal-fired power plant is shown in Fig. 1.1-2 and a somewhat more detailed view of a boiler installation is sketched in Fig. 1.1-3. Space has been allowed for a second unit (right hand side of the page). If this space is subtracted from the total, we can approximate the space requirements for one unit. Rail lines surround the plant and parking lots, security fences, guard shacks, administration buildings, and the like are not shown. 


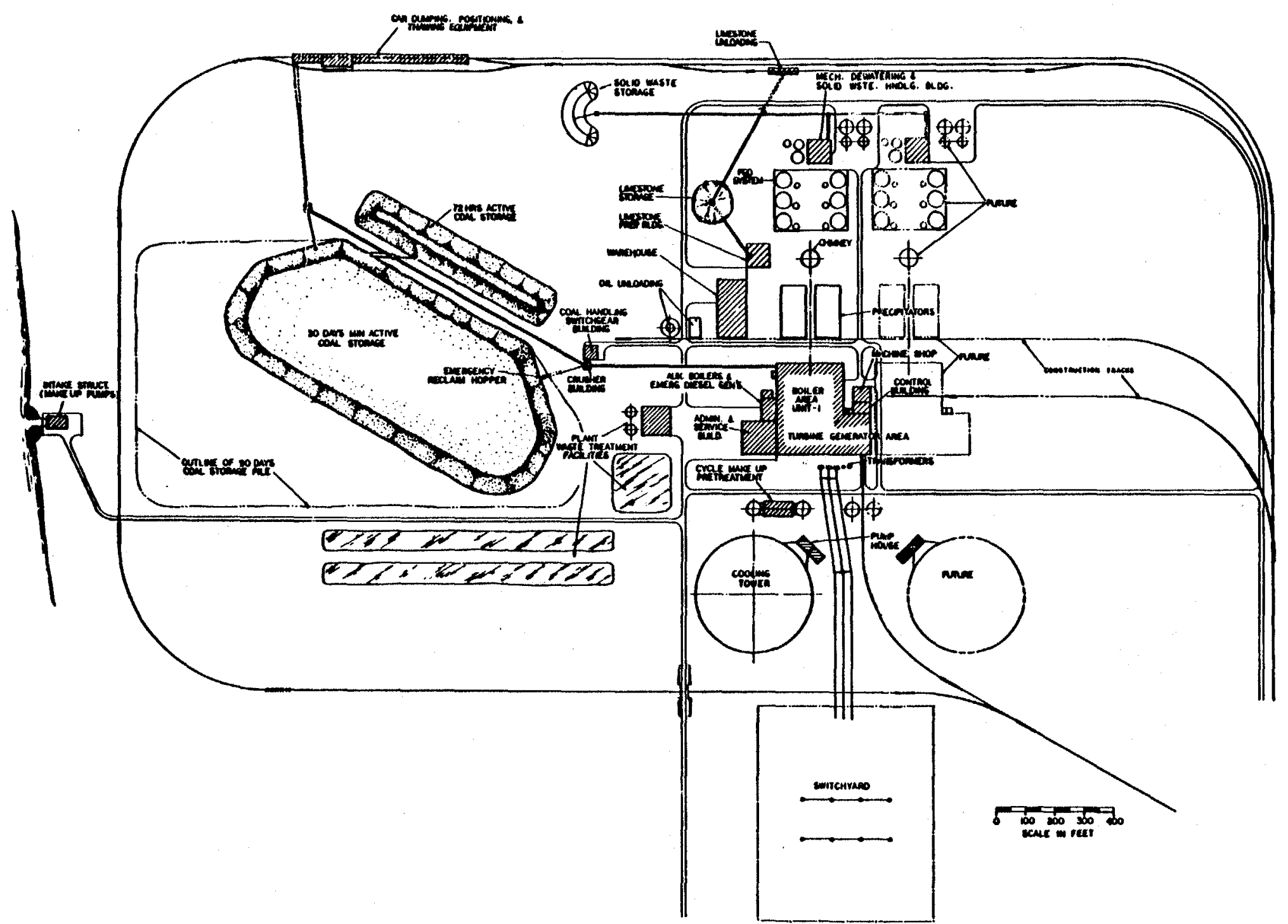

Fig. 1.1-2 A plot plan for a typical, large, coal-fired power plant; reproduced from C. R. Bozzuto. 2 Facilities are shown for size comparison only. The final location will be determined by geological and meteorological conditions. 


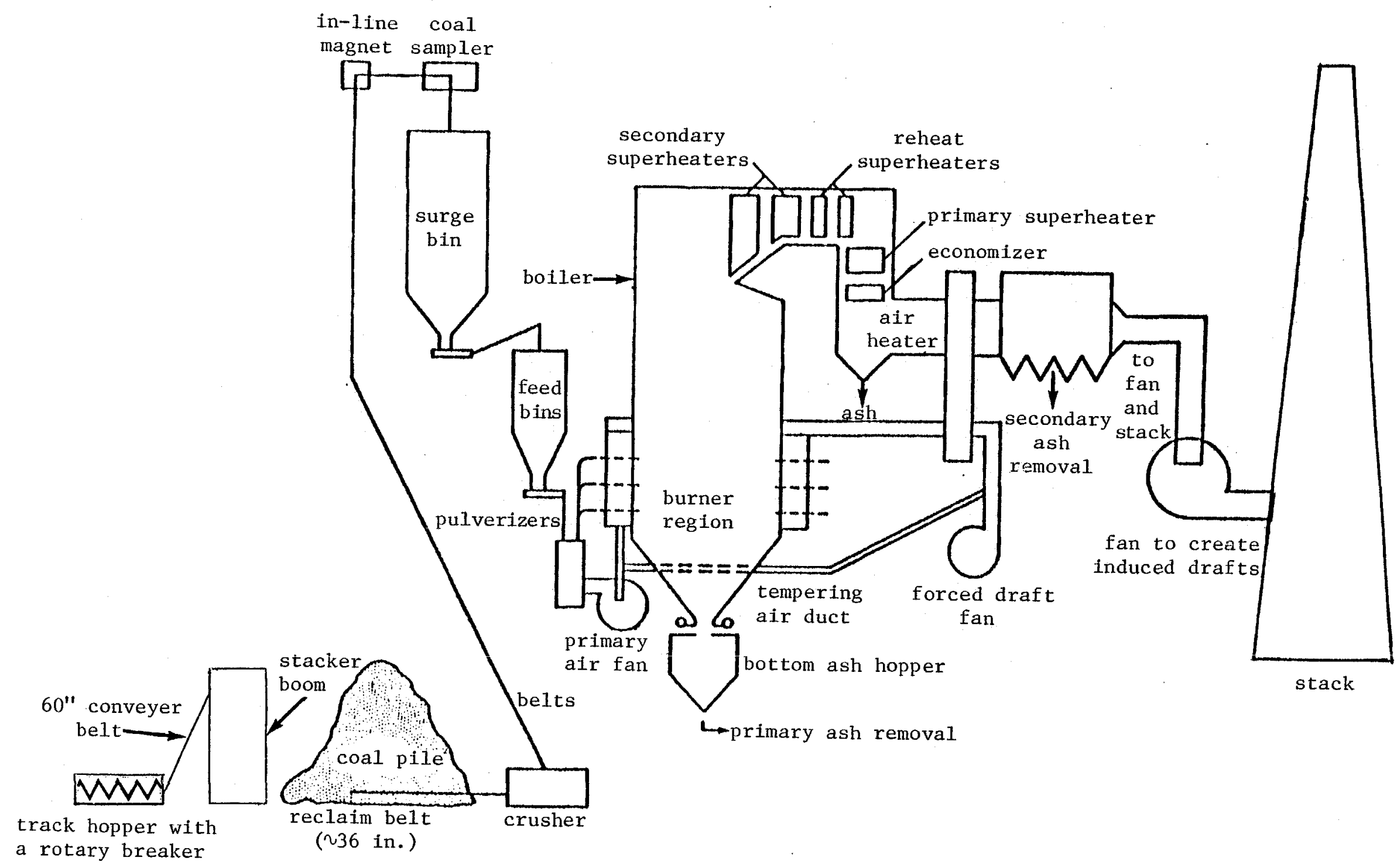

Fig. 1.1-3 Schematic diagram showing the principal components of a utility boiler unit burning pulverized coals. 
The space required for boiler unit one with precipitators and scrubbers is about $14 \%$ of the total space. The waste-treatment facilities shown at this site assume that major ash and sludge disposal are made off-site. If a 20-year ash/sludge disposal area were on-site, it would be at least double the area of the coal pile. In general, when we consider alternative, coal-fired power generation, we are considering changing the equipment within this $14 \%$ enclosure.

The Federal Energy Regulatory Commission (FERC) uses a code of accounts to tally direct costs. These account numbers can be further broken down to provide the level of detail needed by an A/E company to carry out a major project. For government projects (TVA, DOE, DOD, etc.), the FERC code of accounts is generally used. Each A/E firm may have its own internal account system. This fact causes considerable confusion when discussing costs. For example, the feedwater system can be allocated to the turbine or to the boiler. Boiler manufacturers prefer to allocate the feedwater system to the turbine because it is not in their scope of supply. However, the FERC code of accounts allocates the feedwater system to the boiler plant. Hence, the cost of the boiler plant may represent different construction items to different evaluators.

Using the FERC system, the capital costs are broken down in $\$ / k W_{e}$ as shown in Table 1.1-1. These data are approximate and final estimates are site-specific. Nevertheless, a review of the costs shown in Table 1.1-1 indicates that most of the power plant costs are fixed when coal firing is employed. In changing from pulverized coal to fluidized beds to gasified coal to MHD, basically only the boiler and gas-cleanup system are changed. The remaining items are largely predetermined and dependent on the amount of coal fired. These fixed costs generally amount to about $\$ 800 / \mathrm{kWe}$. Some money must be spent on equipment that replaces the boiler and gas cleanup. This cost is about $\$ 200 / \mathrm{kW}_{\mathrm{e}}$ $( \pm 30 \%)$. Thus, all coal-fired plants cost $\$ 1000 / \mathrm{kW}_{\mathrm{e}}( \pm 6 \%)$ in 
Table 1.1-1. Capital costs for a typical, large, coal-fired plant; reproduced from Ref. 2 .

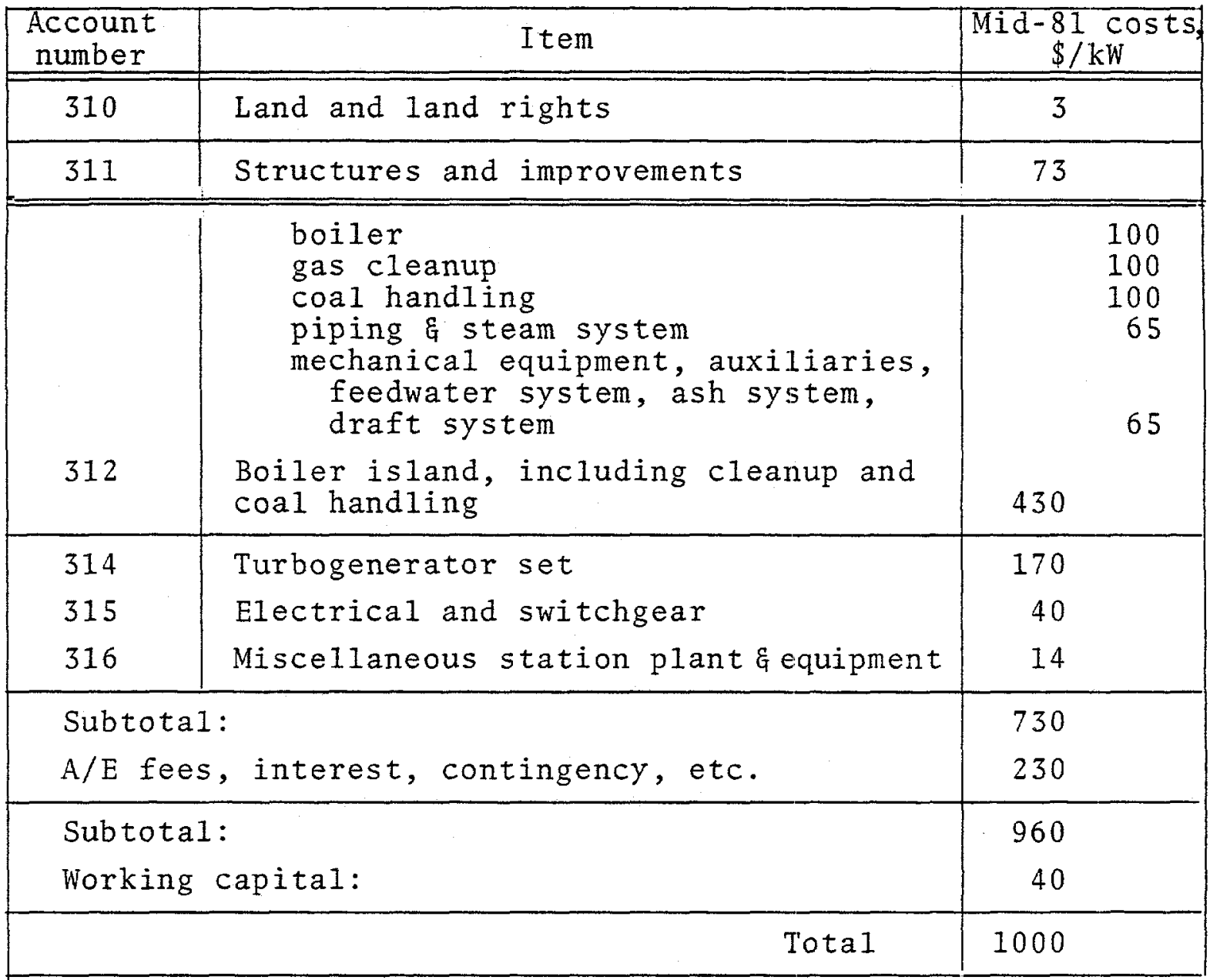

mid-1981 dollars. It is easy to see why utilities are reluctant to build plants using new technology. Capital cost savings are sma11. At best, only substantial operating-cost reductions will be achieved. It is, however, difficult to obtain real operating savings with unproved equipment. A reduction in capacity factor always results in an operating 1oss. Therefore, it is generally more cost-effective and prudent to utilize known technology than risk chasing elusive operating gains based on applications of developing technologies that have not been tested on large scales. 
Nuclear plants cost $\$ 1500 / \mathrm{kW}_{\mathrm{e}}$ within $10 \%$. About $\$ 100 / \mathrm{kW}$ (within 10\%) is the cost of the initial fuel load. Assuming that the cost of the first load is included (approximately 2 operating years of fuel), then about $\$ 87 / \mathrm{kW}_{\mathrm{e}}$ could be subtracted from the nuclear plant to put it on a 90-day fuel basis. However, since the core is normally maintained with a full load of fuel, it is proper to treat the fuel load as required working capital in the same manner as the 90-day coal pile and, hence, no subtraction is necessary.

The overall plant economics depend on a number of assumptions, such as the fixed charge rate, fuel cost, capacity factor, heat rate, etc. The following are representative (mid-1982) assumptions: fixed charge rate $=18.2$ to $25.6 \%$, depending on interest rates and tax laws; fuel costs (levelized for 30 yrs) $=\$ 3.00$ to $\$ 4.00 / \mathrm{MM}$ Btu for coal, $\$ 1.70 / \mathrm{MM}$ Btu for nuclear energy, $\$ 10.00 / \mathrm{MM}$ Btu for oil \& gas; capacity factor (levelized) = 70\%; heat rate $=9,500 \mathrm{Btu} / \mathrm{kW}_{\mathrm{e}}-\mathrm{hr}$ for coal, $10,500 \mathrm{Btu} / \mathrm{kW}_{\mathrm{e}}-\mathrm{hr}$ for nuclear energy, $9,000 \mathrm{Btu} / \mathrm{kW}_{\mathrm{e}} \mathrm{hr}$ for oil \& gas. On the basis of these estimates, we obtain the capital and fuel charges (in mills/ $\left.k W_{e}-h r\right)$ listed in Table $1.1-2$. It is instructive to examine these costs. They show that, on the average, coal is cheaper than nuclear energy, except where coal costs are high (e.g., in New England). Oil prices would have to drop by about a factor of two for new oil-fired units to be competitive. Capital represents about half the cost of electricity (COE) in the case of coal.

Table 1.1-2 Costs in mills/kWe-hr for various fuels (see the text for listed assumptions); reproduced from Ref. 2 .

\begin{tabular}{|l|c|c|c|}
\hline Cost contribution & Coal & Nuclear energy & Oi1 \\
\hline \hline Capital charges & $\begin{array}{l}4.75 \\
\text { Fuel costs }\end{array}$ & $\begin{array}{r}62.62 \\
17.85\end{array}$ & $\begin{array}{r}25.05 \\
90.00 \\
\text { OGM }\end{array}$ \\
\hline $\begin{array}{l}\text { Total cost of } \\
\text { electricity (COE) }\end{array}$ & $78.25(87.25)$ & 85.00 & 5.00 \\
\hline
\end{tabular}

*These are 1982 DOE cost estimates. 
For oil, fuel is about $75 \%$ of the COE, which accounts for the high fuel-adjustment charges in New England (especially in Massachusetts). It is significant to note that no nuclear units* and no large oil- or gas-fired units have been ordered in the U.S. since 1974.

Coal is delivered by rail to the site (see Fig. 1.1-2) where it is dumped, thawed (if necessary), and transported to the coal pile. About $6000 \mathrm{t} /$ day must be delivered for each 500 Me unit, which correspond to about 60-100 cars per day. Coal from the pile is conveyed to a crushing station to reduce the size to $1-1 / 2 " \times 0$ so that the coal can enter a pulverizer. The coal is then transported to the pulverizers, where it is ground to $70 \%$ through 200 mesh and dried. The pulverized coal is conveyed pneumatically with 15 to $30 \%$ of the combustion air required to burn it. The mixture is injected through fuel nozzles and mixed with the rest of the combustion air, which is at a higher preheat temperature. The coal is burned out in the radiant portion of the boiler and the combustion products are cooled below the ash-softening temperature before leaving the radiant section and entering the convective steam superheater, to avoid fouling by molten ash particles. After the gas is cooled to about $750^{\circ} \mathrm{F}$ in the convective superheater and feed water heater (economizer), it is used to preheat air. Here the flue gas is cooled to about $300^{\circ} \mathrm{F}$. It is finally subjected to particulate removal, which is followed by $\mathrm{SO}_{2}$ removal. The cleaned gas is then routed to the stack. Some flue gas reheat may be necessary to protect fan and stack equipment. Typically, a $175^{\circ} \mathrm{F}$ stack temperature is sufficient for effective plume rise. Ash is collected from ash hoppers at several boiler locations and from the particulate removal system. The ash may be mixed with sludge from the wet scrubber system for stabilization or may be disposed of separately.

Water is taken from the condenser and pumped through various feedwater heaters and a deaerator to the economizer section of the boiler. This procedure preheats the water to a temperature near to but less than the boiling point. The water is then transported to a steam drum, where it is mixed with the water-

\footnotetext{
*A 1978 two-unit order has been deferred indefinitely but not cancelled.
} 
steam mixture that is circulating within the waterwalls of the boiler. In the steam drum, steam is separated from the water and sent on to the superheater. The water is recirculated to the lower headers of the waterwalls. Because this water absorbs heat, steam is formed, thus creating a steam-water mixture that rises to the steam drum. The superheated steam is sent to the steam turbine, where a part of its enthalpy is recovered. The steam is now at a lower temperature and pressure and is returned to the boiler to be reheated. This is necessary to ensure that the steam can be expanded to sufficiently low pressure (e.g., 0.04 atm) without significant condensation in the turbine. The reheated steam is returned to the turbine for final conversion to shaft work. Exhaust steam is condensed by cooling water in the condenser. Steam may be extracted from the turbine at various points to heat feedwater. This practice serves to improve cycle efficiency by routing a portion of the working fluid around the condenser. An important consequence of the regenerative feed-water heating is that the feed water arrives at the boiler at saturation temperature and hence no economizer needs to be included in the convective section of the boiler. In order to cool the flue gas effectively in the boiler, the air preheater is enlarged, and it is a special advantage of pulverized coal combustion that advantage can be taken of increased air-preheat temperature; in stokers, this cannot be done because the combustion air must cool the grate. The cooling water is sent to a cooling tower to reject its heat to the atmosphere.

The maximum Carnot efficiency for such a plant, using $1000^{\circ} \mathrm{F}$ steam and $120^{\circ} \mathrm{F}$ cooling water, is about $60 \%$. In actual practice, about $38 \%$ efficiency is achieved because of stack losses (10-12\%), mechanical efficiency of the turbine ( $88 \%)$, electric generator efficiency (97\%), auxiliary power requirements $(10-12 \%)$, and environmental cleanup and other losses $(4-8 \%)$.

The principal current areas of interest to utilities center on reducing operating costs by improving reliability and 
availability, reducing auxiliary power requirements, and reducing environmental costs. A significant period of time is required to demonstrate effects on reliability or availability.

\subsection{Market Penetration}

The discussion in sect. 1.1B indicates some of the problems involved with market penetration of improved technologies. Utilities cannot afford to pioneer innovations. New technologies will enter the utility market only after (a) favorable economic assessments have been completed and (b) a large-scale, commercial prototype has been adequately tested, either with federal support or through a joint venture involving an industry consortium (e.g., EPRI). In general, a $100 \mathrm{MW}_{\mathrm{e}}$ demonstration plant must be operated for one year at reasonable availability (i.e., $50-70 \%$ ).

It should be noted that other views and procedures determine market policy in other countries. Thus, in Japan, rates of return are determined from a 25 -year perspective for the benefit of the country (not for the benefit of a single industry) and private companies, in cooperation with MITI, pioneer technological assessments (step b). A pervasive case can be made that technological leadership requires dedicated resources for commercial prototypes of high-risk technologies. In a strong economy with financially healthy industries, the private sector has proved in the past to be a preferred source of funds for innovation and commercialization.

\section{ID Relations Between Coal Quality, Boiler Availability, and Power Costs}

The availability of coal-fired U.S. electric power-generating stations has declined irregularly during the decade from 1968 ( $\sim 78 \%$ ) to 1978 ( $\sim 65 \%$ ), while the energy contents of the coals burned were reduced from about $11,800 \mathrm{Btu} / 1 \mathrm{~b}$ to about $10,700 \mathrm{Btu} / 1 \mathrm{~b}$. The quantitative relations between coal quality and generating capacity are complicated by the fact that boiler operating availability has declined from about $90 \%$ for $100-200 \mathrm{MW}$ units to about $82 \%$ for units larger than $800 \mathrm{MW}_{\mathrm{e}}$. The relations between 
these parameters require elaboration, which is expected to be obtained as the result of an EPRI program at the National Coal Combustion Test Facility (CCTF) in Homer City, PA. Tests at the CCTF will include combustion evaluations of cleaned and run-of-mine coals. Studies of this type at the TVA indicated substantially higher maintenance costs (27.24 vs. 15.61 cents/t in 1968) for a representative low-quality $(13.4 \%$ ash, $2.7 \% \mathrm{~S}, 12,053 \mathrm{Btu} / 1 \mathrm{~b})$ coal than for a higher quality (10.8\% ash, $1.0 \% \mathrm{~S}, 12,680 \mathrm{Btu} / \mathrm{lb})$ coal. 3 Additional work of this type is described in more recent reports. 4,5

Of particular importance are fuel effects on boiler outages. A Combustion Engineering boiler availability study (1977-79) showed that forced outages and corresponding output reductions were attributable to the following causes: economizer, 45-47\%; superheater or reheater, $27 \%$; pulverizer, $21 \%$; other failures, 5-7\%. ${ }^{6}$ A number of fuel-related tube failures was identified, viz.: sootblower erosion was responsible for $12.8 \%$ of waterwal1 failures and $9.4 \%$ of superheater/reheater failures; damage caused by falling slag caused $11.5 \%$ of waterwal1 failures and $0.9 \%$ of superheater/reheater failures; flyash erosion was responsible for $12.1 \%$ of superheater/reheater failures and $3.6 \%$ of waterwal1 failures; overheating produced $8.5 \%$ of superheater/reheater failures and $3.8 \%$ of waterwal1 failures; $0.5 \%$ each of waterwall and superheater/reheater failure was attributed to external corrosion.

Reduced coal quality also causes reduced life for pulverizer equipment because increased amounts of generally more abrasive materials must be handled.

\subsection{E Some New Commercial Designs}

Currently available commercial designs include boilers for the direct utilization of lignite (see Fig. 1.1-4). To burn fuels with such high water contents, the temperature of the primary air had to be raised, which was accomplished by replacing two vertical, trisector air heaters by two primary and two secondary vertical shaft air heaters. In this configuration, 


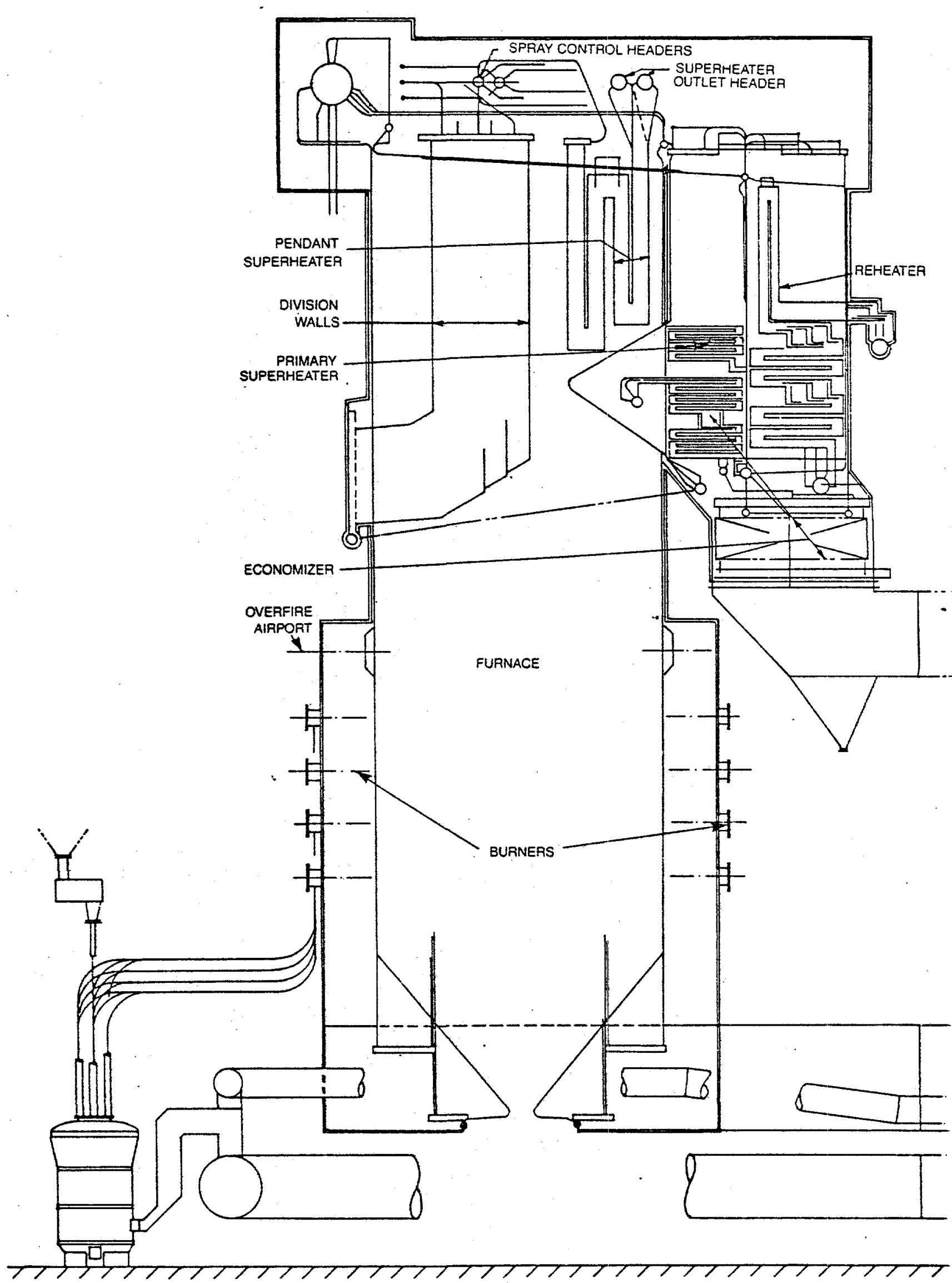

Fig. 1.1-4 Schematic diagram of a commercial boiler (Foster Wheeler Corp.) for the direct combustion of pulverized lignite and other fuels. This is the Rodemacher Unit 2 of a $530 \mathrm{MW}_{\mathrm{e}}$ plant of the Central Louisiana Electric Company. 
damper biasing could be used to distribute the gas flows. Control of air flows between primary and secondary preheaters is a key feature of designing utility boilers that can accommodate a wide range of fuel types.

Another recent development involves utilization of utilitysupplied steam in a reboiler to produce lower temperature steam for such industrial applications as soybean processing. The burning of municipal refuse has been found to be useful for the production of steam along established lines long used in the pulp, paper and sugar industries with steaming capacities up to $600,000 \mathrm{lb} / \mathrm{hr}$.

Al1 aspects of the coal-utilization processes represent important technological and processing challenges, beginning with mining and distribution of the fuel.

1.1F Coal Preparation and On-Site Coal Handing for PCCs According to a classification system that was proposed some years ago, ${ }^{7}$ coal preparation is accomplished in either direct systems (with the pulverizing mill under pressure, suction or selfventilating) or indirect systems that are either open circuits, closed circuits or dual circuits (a11 with or without storage bins). All of these systems have well recognized advantages and disadvantages. For example, in a direct system with a pressurized pulverizer mill, the air-delivery fan is located upstream of the mill and is therefore not subjected to heavy wear. On the other hand, the use of wet coals may then require coal predrying because of limited total air-flow rates and potential ignition hazards. Similarly, in an open circuit indirect system, the coal is dried by the hot combustion products, which requires, in turn, efficient precipitators to prevent coal dust from escaping with the dryer gases.

Boiler manufacturers generally have adequate control over coal preparation, management of coal injection techniques, and product-stream flows and it is therefore reasonable to view these 
operational steps as properly addressed during the plant-layout and design phases. Facilities, materials handling, coal sampling, coal testing, storage, conveying, crushing below-grade coal, reclaiming, blending, coal feeding, coal-dust control, fire prevention, and related problem areas dealing with plant-site coal handling are well summarized in a recent report dealing with these important subjects. 8

\subsection{G Research on Coal Combustion}

Fundamental studies on direct coal combustion have been under way for a long time. Early work dealt with predictions and observations of devolatilization and burning rates for single coal particles, while current studies relate to numerical modeling.

Nusse $1 t^{9}$ introduced the idea that steady-state propagation of a plane flame through a dust cloud is determined by radiant heat transfer, an idea which has been elaborated by Essenhigh and $\mathrm{Csaba},{ }^{10}$ who allowed for $10 \mathrm{cal}$ temperature differences between the burning particles and the gaseous medium.* Overall descriptions of coal burning rates were generally used ${ }^{9-11}$ until about a decade ago. A recent review of pulverized coal-conversion models by smoot ${ }^{12}$ includes a summary of multidimensional pulverized coal-reactor models published since 1970. A model described in Ref. 12 involves turbulent flow with turbulent combustion, particulate size distributions with particle dispersion in the turbulent medium, devolatilization of pulverized coals associated with rapid heating and followed by heterogeneous reactions involving the residual chars. While the reaction processes remain greatly oversimplified, a sufficiently extensive data base exists to allow the judicious use of empirical parameter for various coal ranks (e.g., lignites and bituminous coals)

*More recent studies, carried out at the International Flame Research Foundation, have, however, shown that the prevailing mode of heat transfer that brings the unignited pulverized coal to ignition is convection from hot burned gas rather than radiation; cf. J. M. Beér, "The Effect of Fineness and Recirculation on the Combustion of Pulverized Coal," J. Inst. F. 37, 287-313 (1964). 
in conjunction with measurement programs. Radiative and convective heat transfer may be reasonably well described. Pollutant formations $\left(\mathrm{NO}_{x}\right.$, particulates, $\mathrm{SO}_{x}, \mathrm{H}_{2} \mathrm{~S}, \mathrm{NH}_{3}, \mathrm{HCN}, \mathrm{CO}$, a wide range of hydrocarbons and of organic nitrogen, sulfur, and oxygen compounds) are not generally given quantitatively and pose an important problem area for future research. In fact, all aspects of combustion modeling remain incomplete and a special challenge for the astute investigator is posed by the need to search for the least detailed description that will allow practically useful predictions relating to process control, scaling, and effluent outputs.

\subsection{Coal Slurries}

While coal-slurry pipelines have been used on small scales since 1914, the combustion of coal slurries in the form of coaloil mixtures (COM), coal-water mixtures (CWM), or coal-methanol mixtures (CMM or methacoal) should be viewed as developing technologies, either for retrofitting in oil-burning utility and industrial boilers or for utilization in newly designed equipment. These applications are meant to replace or diminish existing and future oil consumption outside of the transportation sector.

\section{$1.2 \mathrm{~A} \quad \mathrm{COM}$}

COM was used successfully during the sixties at the National Coal Board-Esso and the Bethlehem Steel Corporation in blast furnaces in experiments designed to determine rheological properties. An early demonstration of COM use in a boiler was performed at the General Motors Corporation. Two major utility demonstrations have been completed recently. Thus, an $80-\mathrm{MW}$ e plant (NEEPSCO, funded by DOE) and a 400-MWe plant (Florida Power and Light Company) were run intermittently over a period of about a year, after making minor alterations in the fuel-handling system but not in the boilers, 
which had been originally designed for oil use. Commercial utilization of COM is being implemented in Japan by a company (Japan COM Co., Ltd.) with substantial assets ( $\$ 220 \times 10^{6}$ for 1982-84, $\$ 174 \times 10^{6}$ for 1984-88) and is funded by Tokyo Electric Co., Inc., Electric Power Development Co., Ltd., and several other industrial concerns. Technical information on COM and CWM has been collated at annual symposia dealing with coal-slurry utilization. ${ }^{13}$

Usable COM must be stable over periods of weeks and preferably months, the rheological properties must allow ready pumping and atomization, and the COM mixture must be amenable to efficient combustion with pollutant outputs that meet applicable emissions standards. Generally, stability improves at the expense of increased viscosity. However, the use of surfactants $(\sim 1 \%)$ and water $(\gamma 5 \%)$ has allowed the production of acceptable COM (e.g., 50 wt. $\%$ of coal with $80 \%$ of the coal finer than $76 \mu \mathrm{m}$ in dimensions). ${ }^{13}$ Commercial equipment has been used for stirred storage tanks, positive displacement pumps, and approximate metering of COM flows. Improved designs for all of these facilities are, however, desirable. ${ }^{13}$ Fine atomization $\left(\tilde{\varkappa}_{300 \mu m}\right.$ diameter droplets) in the boiler is required for efficient combustion. The control of slagging and the development of improved and longlived atomizers represent major R\&D challenges. The flame stabilities achieved with COM have been excellent.

Single COM droplets ignite more readily than oil drops. Subsequent burning simulates oil flames early and the burning of coal char toward the end of combustion. ${ }^{13,14}$ The combustion properties and pollutant outputs are strongly dependent on both the oil composition and the particular coal used. These phenomena are understood to some extent. ${ }^{14}$ Thus, bituminous coals decompose early and some of the high molecular weight tars formed are extracted by the remaining oil phase. The partially devolatilized coal residues swe11, agglomerate and then rupture to permit escape of volatiles before they burn out as char cenospheres. ${ }^{14}$ 
Pollutant emissions include particulates, $\mathrm{SO}_{x}, \mathrm{NO}_{x}$, and trace elements, all of which can be partially removed by utilizing commercially available procedures, although cost controls require further improvements. Conversion of an oil burner to COM will require a capital investment of perhaps $\$ 125 / \mathrm{kW}$. Careful assessments remain to be made on recovery of this investment through reduced fuel costs, while applicable environmental emission standards are being satisfied. Without substantially higher oil prices than prevailed early in 1983, CoM techniques are not generally cost-competitive.

A major operational problem has involved slagging in the combustion chamber, especially in the immediate vicinity of the burner inlet. Better control of slagging may be achieved by careful control of flame temperatures and of the fluiddynamics in the two-phase flow systems. Erosion of critical components has been controlled, to some extent, by the introduction of improved hightemperature alloys. Tube spacing will affect fouling, while atomizer wear depends on such factors as particle sizes, injection velocities and heat transfer.

\section{$1.2 \mathrm{~B} \quad \mathrm{CWM}$}

Because COM involves only partial ( 50 wt. $\%$ ) replacement (which corresponds to 30 to $40 \%$ in terms of energy replacement) of oil and is of marginal current economic interest, increased emphasis has recently been placed on the development of CWM. An optimal mixture has $\sim 70 \mathrm{wt} . \frac{\circ}{6}$ of coal, $330 \mathrm{wt} . \%$ of water and some additives. Operational problems are analogous to those encountered with COM, although important differences exist in practice.

The viscosity and stability of CWM are controlled by using 1 to $2 \mathrm{wt} . \%$ of additives. The use of beneficiated coals ${ }^{15}$ is under study for the purpose of reducing ash levels below $3 \%$.

Injection, atomization and combustion have been achieved but require considerable development before an optimized system is designed in demonstration and commercial plants. Using the relatively small amounts of CWM that have been available, carbon conversions in the range 85-99\% have been achieved. Such 
problems as flame stability, nozzle erosion, $\mathrm{NO}_{\mathrm{x}}$ control, slagging, ash formation, and fouling are currently under investigation. 16

\subsection{CMM}

Coal-methanol and other coal-alcohol mixtures have been studied to some extent (e.g., at the Pittsburgh Energy Technology Center). Much pertinent information relating to this interesting subject has not been released by private developers. CMM is more costly than CWM per unit of combustion energy but also has operational advantages (e.g., by allowing pumping of liquid slurries at low temperatures), which may justify the required incremental costs. In the absence of large-scale testing, it is too early to attempt an assessment of the suitability of CMM for commercial applications.

\subsection{Market Penetration of Coal Slurries}

When a coal-based fuel is employed in a utility plant, most of the powerplant components (e.g., the boiler island with coal handing and cleanup facilities, the turbogenerator set, electrical and switch gear, structures and improvements, etc.) represent fixed-cost items. When pulverized coal is replaced by COM or CWM or the boiler is changed to a fluidized bed reactor, modifications may be required in the designs of boilers and gas-cleanup systems. For retrofitting oil burners for the use of COM or CWM, 1imited additional capital costs may be justified provided lower operating costs are reasonably anticipated.

From the point of view of an operating utility, there must be heavy emphasis on reliability and availability of the generating station. Generally speaking, utilities in the U.S. market cannot afford to pioneer innovations. New technologies will enter the U.S. utility market only after (a) favorable economic assessments have been completed and (b) a large-scale, commercial prototype has been adequately tested, generally with support from a federal agency (DOE) or an industry consortium (EPRI). While step (a) has been achieved for CWM but appears doubtful for COM, step (b) remains to be implemented for CWM but has been performed to some extent for COM. 
When a long-term perspective is taken with the view of benefitting the country over the long term, as in Japan or the FRG, large-scale pioneer technological assessments may be more readily justified.

\subsection{E Combustion R\&D Status of COM}

i. Introduction

Sporadic use of coal-oil mixtures in marine boilers (tankers) and in blast furnaces has a history of several decades. In the mid-1960s, the Bethlehem Steel Co. and the National Coal Board-Esso carried out systematic experiments on the rheological properties of COM and demonstrated the technical feasibility of burning coal in the raceways of blast furnaces to replace expensive metallurgical coke partially by COM. The main objective was to use pulverized coal and the oil served as a transport medium to permit the more convenient hydraulic feed-transportation system to be used in place of a pneumatic system. Combustion studies at several laboratories have served to emphasize the necessity of matching coal and oil combustion properties and showed wide-ranging variations in carbon combustion efficiency when different types of coals were used. More recently, results of systematic combustion studies carried out at the DOE Pittsburgh Energy Technology Center have been reported in the four international symposia on COM combustion organized annually since 1978. 13 These symposia are the main source of technical information on fuel preparation, rheological properties (stability, viscosity), atomization, and combustion of COM. Following an earlier demonstration experiment in a boiler at a General Motors Company plant, which showed encouraging results for the use of COM in an industrial steam-raising plant, two longer term trials were carried out in utility plants by NEEPSCO $\left(80 \mathrm{MW}_{\mathrm{e}}\right)$ and by FPL 
$\left(400 \mathrm{MW}_{\mathrm{e}}\right)$. These showed that long-term operation of utility boilers with COM is feasible after relatively small alterations to plants and requires little derating. These last conclusions are, however, site-specific and depend on the original design of the retrofitted boiler.

\section{ii. COM Preparation and Handling}

Successful introduction of COM into industrial use requires that the mixture be stable (i.e., the coal particles do not settle out over a period of weeks) and that the rheological properties be favorable (the mixture can be pumped and atomized). It is also desirable to increase the coal content as much as possible and to use particle sizes which do not require excessive grinding energy for their preparation.

The relationships between these variables show that good stability and favorable rheological properties have conflicting requirements. Thus, the stability improves but the viscosity of the mixture increases with increasing coal concentration, finer particle sizes and increasing oil viscosity. Additions of small amounts (up to $5 \%$ ) of water and about $1 \%$ of surfactant can produce an acceptable solution, e.g., $50 \mathrm{wt} . \%$ coal ground to a fineness usual in power station practice $(80 \%<76 \mu \mathrm{m})$.

The mechanism of COM stabilization is poorly understood. The action of the chemical additives is explained by their effects on electrostatic, steric and flocculated networks in the fluid but the relationships between additive properties and COM stability are, at best, semi-empirical. Improved understanding in these areas is desirable.

COM with less than $40 \%$ coal concentration and without water behaves as a Newtonian fluid; COM is pseudoplastic for higher coal concentrations. For these conditions, the shear stress $\tau$ can be expressed as $\tau=k \dot{\gamma}^{\mathrm{n}}$ where $\dot{\gamma}$ is the shear rate $\left(\sec ^{-1}\right)$ and $n<1$. 
Water and additives influence the $k$ and $n$ values; higher $\mathrm{k}$ values are associated with improved stability. The smaller the value of $\mathrm{n}$ is, the lower will be the viscosity under flow conditions. Additive selection and optimization of concentrations of water and additives are determined from optimizations involving $\mathrm{k}$ and $\mathrm{n}$.

\section{iii. Storage, Pumping, Flow Metering}

Stirred storage tanks and special positive displacement pumps and flow-metering devices for handling COM are commercially available. R\&D is needed in this area for design optimization of stirred tanks, for increasing availability of pumps, and for further development of the presently available mass-flow metering devices.

\section{iv. Atomization}

High atomization quality (i.e., sufficiently fine atomization with a minimum of droplets in excess of $300 \mu \mathrm{m}$ ) is a prime requisite of good COM combustion and may be accompanied by reduced slagging tendency. In liquid-fuel atomizers, the fluid is forced by high pressure through orifices and thin liquid sheets are formed which, as the result of development of Rayleightype instabilities, break down into ligaments that disintegrate into droplets due to surface tension forces. An exception to this mechanism of liquid break-up occurs in some mechanical atomizers (rotary cups) in which the liquid sheet is formed on the surface of a fast-spinning disk or cup and its break-up is assisted by impinging high-velocity air.

An important engineering problem in COM atomization lies in the high viscosity and abrasive nature of the fuel. Highvelocity flows through nozzles are required to produce fine atomization and may cause unacceptable rates of erosion. The use of special materials in atomizing nozzles has been shown to lead to reduced metal wastage and hence increased atomizer life. The 
alternative solution, i.e., relaxation of atomization quality, is unacceptable since it leads to high solid carbon carry-over. Achievement of improved atomization in COM will require a significant R\&D effort.

Improved atomizers should be developed through better understanding of the physical processes involved and through use of special materials for the structural parts exposed to erosion. Parallel with these fundamental studies, a semiempirical approach to design, coupled with experimental testing of nozzles, will be necessary for early development of improved and acceptable atomizer nozzles. Atomizers should be developed which maintain high atomization quality over a period approaching 1000 hours, before the changing of atomizer tips will become economically and operationally acceptable.

v. Combustion and Pollutant Emissions

The combustion of COM in an industrial type turbulent diffusion flame is dominated in the near field (i.e., close to the burner) by characteristics of the oil flame and, in the far field, by the burn-out of the residual coal char towards the end of the flame. Studies on single COM droplets have shown that these droplets ignite more readily than oil drops, perhaps because of increased absorptivity to thermal radiation caused by the presence of the solid particles. If a bituminous coal is used, its thermal decomposition commences while the particles are still surrounded by the liquid phase. The high molecular weight tars which evolve from the coal are partially extracted by the oil, and the coal particles swell and produce an agglomerate. On termination of oil combustion, a solid carbonaceous residue is left, which encloses the partially devolatilized coal char particles. As oxygen reaches the surface, the temperature of the char agglomerate is raised, causing further evolution of coal volatiles and an increase of pressure; the carbon surface becomes spherical and, eventually, this cenosphere ruptures to permit the volatiles to escape through a blow-hole. The char cenosphere burns out in the tail end of the flame where the 
temperature is high but the oxygen concentration is low because of the prior combustion of oil and the coal volatiles.

Flame stability obtainable with COM fuels is so good that the recirculation of hot combustion products to the burner could be reduced. Some reduction of recirculation is highly desirable. Otherwise, the combination of resulting high temperatures close to the burner and the possibility of carbon (from unburned fuel) becoming embedded in the wall deposit can cause serious slagging problems.

The atomization quality has to be high because the sizes of the char cenospheres are close to those of their parent droplets and their burning time follows Nusselt's square 1aw, i.e., the burning time is proportional to the square of the initial particle diameter.

It is expected that $\mathrm{NO}_{\mathrm{x}}$ emission from COM will be somewhat higher than from oil alone, mainly because of increased fue 1 nitrogen content of the COM. However, the staged combustion nature of COM, which involves coal nitrogen evolution in an atmosphere in which the $\mathrm{O}_{2}$ has been strongly depleted, tends to reduce $\mathrm{NO}_{\mathrm{x}}$ emission. $\mathrm{NO}_{\mathrm{x}}$ emission has been shown to respond sensitively to variations in the overall amounts of excess air used.

The emission of sulfur will depend on the tota.1 sulfur contents of coal and oil in the mixture. Sulfur reduction is an important consideration in coal preparation, because sufficiently low sulfur contents of the fuel may lead to arrangements that are approved by the EPA and allow operation without flue-gas desulfurization.

Particulate emissions from COM combustion will be higher than from oil burners. It is probable that the EPA will require compliance with present emission standards for retrofitted oil-fired boilers.

The flame emissivity is increased by coal particles and enhanced radiative heat transfer from the flame is expected. However, this process does not produce increased heat transfer in the combustion chamber because of the insulating effect of the ash-slag deposit on heat-exchanger surfaces. In FPL 
demonstration experiments, the flue gas volume had to be increased because of higher excess air requirements for complete combustion and this, together with reduced heat transfer in the combustion chamber, resulted in a higher proportions of the enthalpy of the flue gas being carried into the convective superheater section of the boiler. More research is needed on radiative heat transfer in a partially slagged-up combustion chamber to determine the full implications of these factors upon the distribution of the thermal load over the radiativeconvective parts of the boiler.

\section{vi. Transformations of Coal Ash}

Perhaps the most sensitive area of COM combustion technology is slagging of the combustion chamber caused by deposits of partially molten ash and the carry-over of molten fly ash particles into the convective heat-exchanger section of the boiler. Because of the rapid temperature rise after ignition, slagging may be heavy near the burner unless special care is taken to reduce recirculation of hot combustion products. Large droplets and coal particles may reach the walls and become embedded in the ash deposits, thus causing the fluxing of the molten slag and attack of the slag on the protective oxide film of the heat-exchanger tube surface.

Research is needed to improve our understanding of the transformations of the mineral matter in the coal during the combustion processes and to help define the nature and levels of formation of wall deposits as well, as to predict the physicochemical properties of the fly ash from knowledge of the coalash composition and of the concentration-temperature history of the ash. This type of information will not only serve the designers and operators of boilers and furnaces but will also contribute to the industrial development of coal beneficiation. 
viii. Selected Bibliography

The references 1 isted in the footnote are representative examples of recent publications relating to COM combustion.*

\subsection{F Combustion RED Status of CWM \\ i. Introduction}

Coal-water mixtures (CWM) represent a relatively new area of combustion application. With declining interest in coal-oil mixtures, resulting principally from low economic incentive, interest in CWM has increased, particularly in the U.S., Sweden, Canada, and Japan.

*G. F. Morrison, "Conversion to Coal and Coal/0il Firing," IEA Coal Research, London, No. ICTIS/TRO7 (1979).

C. K. Law, "Disruptive Vaporization of CoM Droplets," Proc. First International Symposium on COM Combustion, St. Petersburg, FL. (1979).

J. M. Beér, W. F. Farmayan, C. Gabriel, M. Toqan, S. Srinivasachar, and L. Monroe, "Combustion, Heat Transfer, Ash Deposition and Pollutant Emission Characteristics of COM," Proc. Fourth International Symposium on COM Combustion, Orlando, FL (1982).

Y. S. Pan, "Effect of Coal Particle Size Consist on the Performance of a COM-Fired Boiler," Proc. Third International Symposium on Coa1-0i1 Mixture Combustion, Orlando, FL. April (1981).

A. Brown, "Final Report on the General Motors Corporation Powdered Coa1-Oi1 Mixture (COM) Program," DOE Report FE 2267-2, U.S. Department of Energy, Washington, D.C., October 1977.

N. H. Cherry and C. C. Stokes, "Use of Dielectric Properties in the Determination of COM Stability," Proc. First International Symposium on COM Combustion, St. Petersburgh, FL (1979)

G. D. Botsaris, Y. M. Glasman and M. Adams-Viola, "Characterization and Structure Studies of Various Types of COM," Proc. Second International Symposium on COM Combustion, Danvers, MA. (1980); J. M. Eckman and D. Bienstock, "The Role of Coal and Oil Characteristics on the Stability of COM," ibid.

A. D. Schmidt and J. L. Friedrich, "Full Scale Tests Firing CoalOil Mixtures in a 400 MW Steam Generator," Proc. Third Symposium on COM Combustion, Orlando, FL (1981).

J. P. Forte, R. H. Hickman, and R. S. Folgueras, "COM Test Program Almeria Power Plant," Proc. Fourth Symposium on COM Combustion, Orlando, FL (1982). 
The papers presented at the 4 th International Symposium on Coal Slurry Combustion ${ }^{13}$ provide a good review of the current status of CWM technology. Of the 93 papers presented, approximately one-quarter dealt with CWM; of these, about 13 were on slurry formation and handling, 1 on atomization, 6 on combustion, and 3 on systems evaluations. Only three of the papers on combustion (from PETC, ARC and B\&W) included data on pulverized coal-water mixtures.

To date, no major technical problems have been encountered in the use of CWM. However, work in this area is new and it will require about 3 years to establish a sufficient data base to evaluate the potential of CWM critically. Important technical areas relate to coal-slurry transport, slurry-fed gasification, and combustion of high-moisture coals.

\section{ii. CWM Preparation/Handling}

About 11 industrial organizations are developing CWM for possible commercial use. Six have developed methods and equipment (pilot plants) for the production of CWMs in the 75-120 tpd capacity range. The presently available technology suggests that optimal mixtures contain about $70 \%$ coal and $30 \%$ water. The blended coal particles generally range from small to large sizes. It is customary to use small percentages $(1-2 \%)$ of additives for the control of viscosity and settling. Claims are made that mixtures are stable for significant periods of time (e.g., one month or more). Independent research (e.g., Eckmann ${ }^{7}$ ) is being conducted on rheological properties of CiM.

Identified research needs in this area include the following :

a. Optimization of CWM, including definitions of particlesize distributions for particulate coal loadings, the use of additives, and the resulting mixture stabilities. 
b. Incorporation of beneficiated coal through fine grinding (micronization) for reductions in ash level. This procedure is being applied to reduce ash levels to $3 \%$.

Work is continuing in the private sector and with EPRI and DOE support.

\section{iii. Atomization and Dispersion}

Extensive research has not been performed on atomization rates of water in dispersions of coal in CWM. On1y one paper on this subject (from BNL) was presented at the 4 th International Symposium and this discussion referred to coal-loading levels well below practically achievable levels. Workers at DOE/PETC have recently initiated sponsored research in this area at Carnegie-Mellon University. The efficiencies of coal burnout, fouling, and $\mathrm{NO}_{x}$ pollutant formations are all related to droplet atomization, particle dispersion, and the combustion processes. Atomization studies and the associated CWM nozzle designs have been considered in CWM combustion by workers at PETC and ARC. Commercially available nozzles were frequently used in these early combustion studies.

Key research needs on atomization and dispersion include the following:

a. Determinations of variables such as mass-flow rates, pressure levels, and nozzle configurations that control the droplet-size distributions and the droplet and dust-particle dispersions. Relationships must be established between particle-size distributions and droplets formed on injection. The CWMs should cover the ranges of solids loadings, coal sizes and distributions, and additives that are of practical interest. 
b. Determination of the relations between nozzle designs, secondary air-flow patterns, and mixing rates in CWM for the purpose of optimizing burner designs.

These studies will have to be closely linked with the combustion studies defined in the next section. Work on optimum nozzle design is in progress at CE and other laboratories, with and without external support.

\section{iv. CWM Combustion}

Early investigations of the combustion characteristics of pulverized CWMs were performed at ARC, ${ }^{18}$ PETC, ${ }^{19}$ and EPRI/B\&W. ${ }^{20}$ It is apparent from this work that pulverized coal can be burned with high percentages of water. Coal burnout levels up to $98 \%$ have been reported and CWMs containing up to $70 \%$ of coal have been tested. PETC tests were conducted in $100 \mathrm{hp}$ and $700 \mathrm{hp}$ water tube boilers with up to $63 \%$ coal in the CWM. In the smaller unit, up to $85 \%$ carbon conversion was achieved while, in the larger unit, up to $96 \%$ carbon conversion was obtained (with the use of surplus secondary air).

The ARC ${ }^{18}$ investigations on CWM involved coal percentages up to $65 \%$ in a small laboratory furnace $\left(10^{6} \mathrm{BTU} / \mathrm{hr}\right)$. Carbon conversion levels of up to $90 \%$ were reported. More recent tests ${ }^{21}$ have shown combustion efficiencies up to $95 \%$ with $70 \%$ CWM in the small-scale furnace.

Investigations of CWM combustion are also underway at MIT and BYU. These studies will provide information concerning the flame structure. Plans for larger scale testing of CWM in a utility boiler have been outlined by workers at EPRI and at DOE/PETC/CE.

While early results are encouraging, much work remains to be done to provide a suitable data base for quantitative mode1ing. Important research needs include the following: 
a. Measurements of combustion rates, fouling, and pollutant-formation characteristics of practically usable CWMs, including higher coal solids levels, use of beneficiated coals with low ash contents, and effects of additives. Of particular importance are adequate flame stability, control of nozzle erosion, much higher carbon conversions ( $>99 \%$ ), and post-combustion controls of ash and $\mathrm{NO}_{x}$ levels.

b. Determination of the optimum burner configurations for CWMs remains to be accomplished.

c. Demonstration of successful, long-term operation of CWMs in large-scale, oil-designed utility boilers, with emphasis on slurry mixture stability, flame stability, fouling and ash control, nozzle erosion, high carbon conversion, boiler derating, and moderation of $\mathrm{NO}_{x}$ levels. This applied task must be performed successfully before commercial applications of CWMs can be considered.

There are many unresolved fundamental research questions that relate to implementation of CWM technology. These include the behavior of dispersions of condensed phases in turbulent media, droplet formation and evaporation in three-phase media, devolatilization processes of wet coals, and turbulence in swirling, particle-droplet-laden flows. 


\subsection{G Cost Analysis of the Application of Coal-Water Mix- tures (CWM) to Gas-Turbine Firing}

The following analysis relates to the magnitude of the price differential that may be tolerated when using clean fuel combined cycle (CFCC) plants in gas-turbine applications in place of direct applications of coals. High price differentials (e.g., $\$ 5$ to $7 / \mathrm{MM}$ Btu with respect to oil) have been cited as motivation for developing coal-water mixtures (CWM) for turbine applications. Unfortunately, these cost estimates cannot be correct. Clean fuel combined cycles are available today by firing oil or gas. Very few have been sold because the costs for oil and gas are too high relative to those for coals. The following calculations support this conclusion.

Using realistic estimates of $\$ 600 / \mathrm{kW}_{e}$ for a CFCC plant and $\$ 1000 / \mathrm{kW}_{e}$ for a conventional coal-fired plant, $7000 \mathrm{hrs} / \mathrm{yr}$ operation, fue 1 costs levelized over 30 years, $20 \%$ capital charges, $10,000 \mathrm{Btu} / \mathrm{kWh} \mathrm{e}$ as heat rate for conventional plants, and 8,000 $\mathrm{Btu} / \mathrm{kWh}$ e as heat rate for CFCC plants, the first year fuel-cost differential may be shown to be $\$ 1.38 / \mathrm{MM}$ Btu, as will now be verified.

We list in Table 1.2-1 the costs for conventional and CFCC plants.

The fuel costs are a function of heat rate, leveling factor, and first year fuel price. Based on the EPRI levelizing procedures, the leveling factor will be taken as 2 . The first year coal price is about $\$ 1.50 / \mathrm{MM}$ Btu. Thus, the levelized coal price is $\$ 3.00 / \mathrm{MM}$ Btu. The levelized fuel cost is then

$$
\begin{aligned}
\mathrm{C}_{\text {levelized }} & =(\$ 1.50 / \mathrm{MM} \mathrm{Btu}) \times 2 \times\left(10,000 \mathrm{Btu} / \mathrm{kW}_{\mathrm{e}}-\mathrm{hr}\right) \\
& \times(1000 \mathrm{mil1s} / \$)=30 \mathrm{mil1s} / \mathrm{kW}_{\mathrm{e}}-\mathrm{hr} .
\end{aligned}
$$


Table 1.2-1 Cost comparisons between conventional and CFCC plants.

\begin{tabular}{|c|c|c|}
\hline Costs and charges & Conventional plant & CFCC plant \\
\hline Capital cost & $\$ 1000 / \mathrm{kW} e$ & $\$ 600 / \mathrm{kW}_{\mathrm{e}}$ \\
\hline Capital charges & $\$ 200 / \mathrm{kW}_{\mathrm{e}^{-y r}}$ & $\$ 120 / \mathrm{kW}_{\mathrm{e}}-\mathrm{yr}$ \\
\hline $\begin{array}{l}\text { Annualized electri- } \\
\text { city cost }\end{array}$ & $28.6 \mathrm{mills} / \mathrm{kW}_{\mathrm{e}}-\mathrm{hr}$ & $17.2 \mathrm{mills} / \mathrm{kW}_{\mathrm{e}}-\mathrm{hr}$ \\
\hline Levelized fuel cost & $30 \mathrm{mills} / \mathrm{kW}_{\mathrm{e}}-\mathrm{hr}$ & $\mathrm{Y} \operatorname{mills} / \mathrm{kW}_{\mathrm{e}}-\mathrm{hr}$ \\
\hline $\begin{array}{l}\text { O\&M (including lime- } \\
\text { stone) }\end{array}$ & $8.4 \mathrm{mills} / \mathrm{kW}_{\mathrm{e}}-\mathrm{hr}$ & $3.9 \mathrm{mills} / \mathrm{kW}_{\mathrm{e}}-\mathrm{hr}$ \\
\hline Total energy costs & $67 \mathrm{mills} / \mathrm{kW}_{\mathrm{e}}-\mathrm{hx}$ & $21+\mathrm{Y} \operatorname{mills} / \mathrm{kW}_{\mathrm{e}} \mathrm{e}^{-\mathrm{hr}}$ \\
\hline
\end{tabular}

For a heat rate of $8000 \mathrm{Btu} / \mathrm{kW}_{\mathrm{e}}$-hr with $\mathrm{CWM}$, the allowable levelized clean fuel price differential is (compare Table 1.2-1)

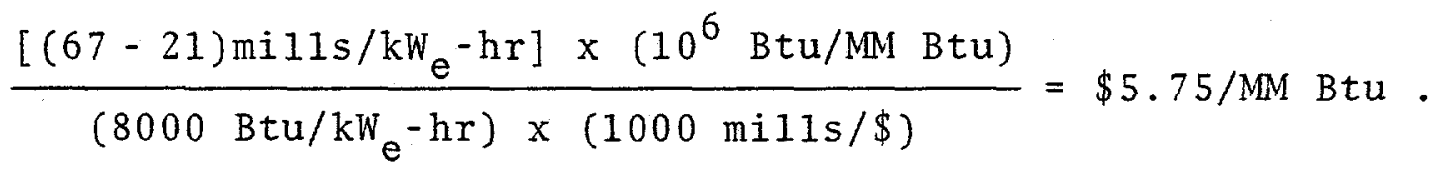

The corresponding actual first year clean fuel price is thus seen to be $\$ 2.88 / \mathrm{MM}$ Btu. Therefore, the differential first year fuel price between coal-water mixtures and conventional coals must be less than \$2.88-\$1.50/MM Btu or \$1.38/MM Btu. The coalwater mixture fuels must meet all gas-turbine and environmental regulations and specifications. These include at least $90 \%$ sulfur removal, $99 \%$ particulate removal, and sufficient nitrogen removal to meet $\mathrm{NO}_{x}$ specifications. The required degree of beneficiation has not yet been obtained at reasonable cost. Coal liquefaction and coal gasification will yield clean fuels but at prices equal to roughly double the current costs for oil or gas (which are substantially larger than $\$ 1.38 / \mathrm{MM}$ Btu).

Unless the required coal-beneficiation costs can be reduced below about $\$ 1.38 / \mathrm{MM}$ Btu, it is unlikely that CFCC plants using CWM will become economically competitive with conventional coal-fired plants. 


\subsection{Atmospheric-Pressure Fluidized-Bed Combustors (AFBCs)}

Both atmospheric and pressurized fluidized-bed combustors are under active development because of the following potential advantages: greatly enhanced flexibility in fuel use, lower costs than conventional systems in meeting environmental regulations (pollutant control is facilitated by employing limestone in the reactor to remove $\mathrm{SO}_{2}$ while reducing $\mathrm{NO}_{\mathrm{x}}$ production through lower combustion temperatures), simplified operation because of the absence of sootblowers and greatly reduced slagging, lower maintenance costs, reduced size and busbar costs in utility applications, and reduced cost sensitivity to unit size.

Industrial AFBCs are commercially available. However, the larger units required for utility applications remain to be designed, built, tested, and demonstrated.

\subsection{A Commercial and Prototype Developments of AFBCs}

It has been said ${ }^{22}$ that fluidized beds represent an evolution in coal-fired power plants from the stoker and pulverized coal burner (see Fig.1.3-1 for a schematic diagram illustrating burner shapes). Details of representative industrial fluidized-bed steam-generators are shown in Figs.1.3-2 to $1.3-5$ and have been reproduced from a paper by $R$. L. Gamble. ${ }^{23,24}$ Figure $1.3-2$ is an example $\mathrm{e}^{23}$ of a DOE-subsidized $A F B C$ demonstration $p l a n t$ and was designed to produce steam for the Georgetown University campus. The unit was built by the Foster wheeler Energy Corp. Shakedown of operation required improved control of erosion prevention and modifications in the bag house. Generally speaking, design changes and improvements may be needed during shakedown in AFBC for commercial applications using different types of coals. 


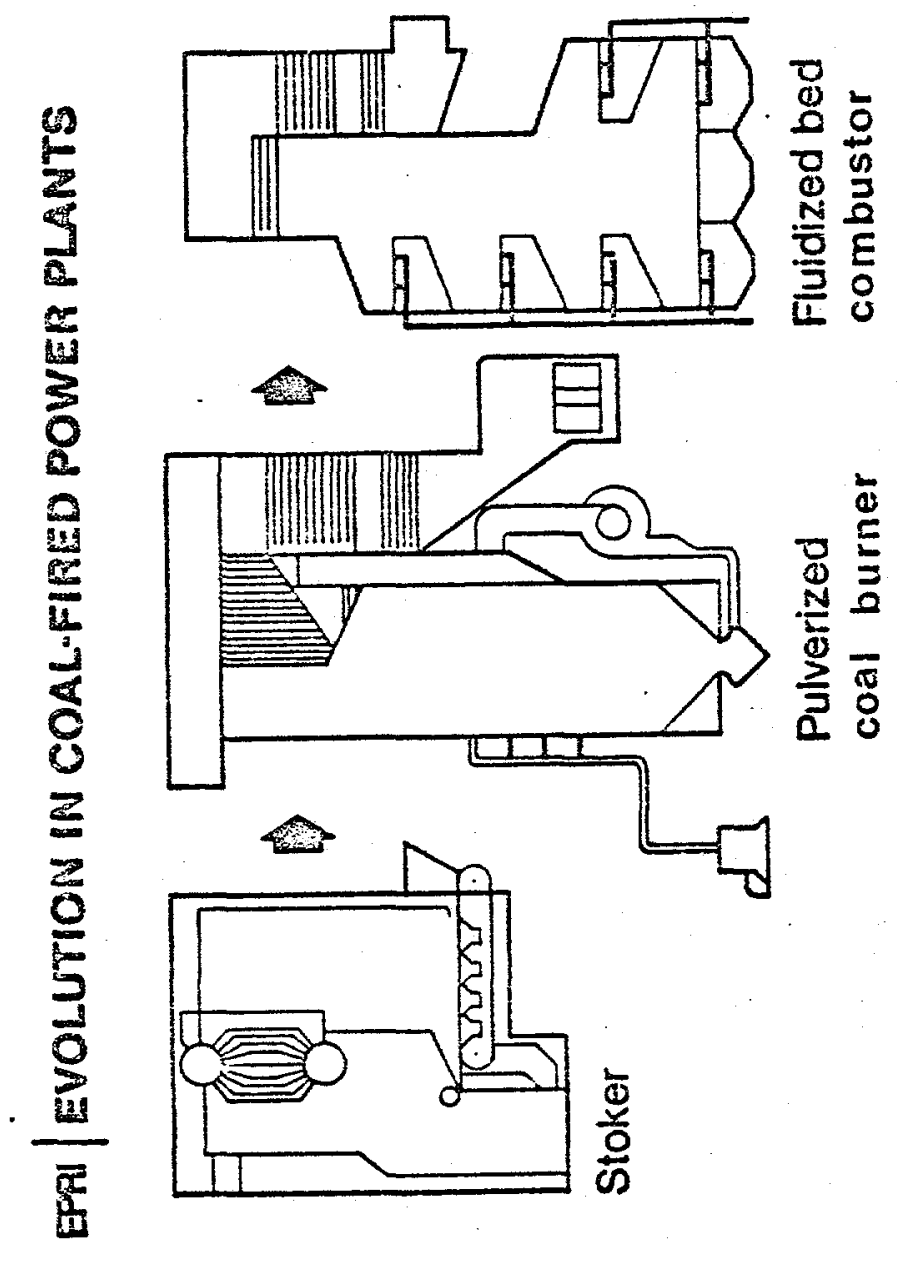

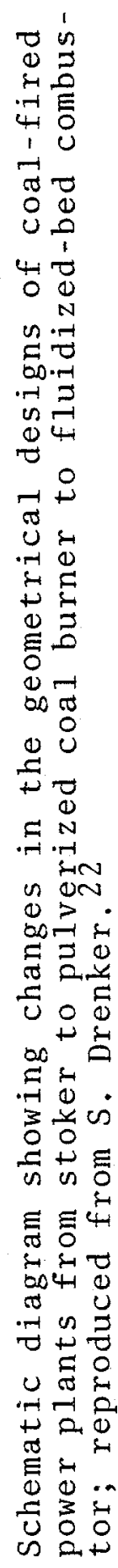

+1
$\dot{1}$
-1
$\dot{0}$
$\dot{D}$
$\dot{1}$ 


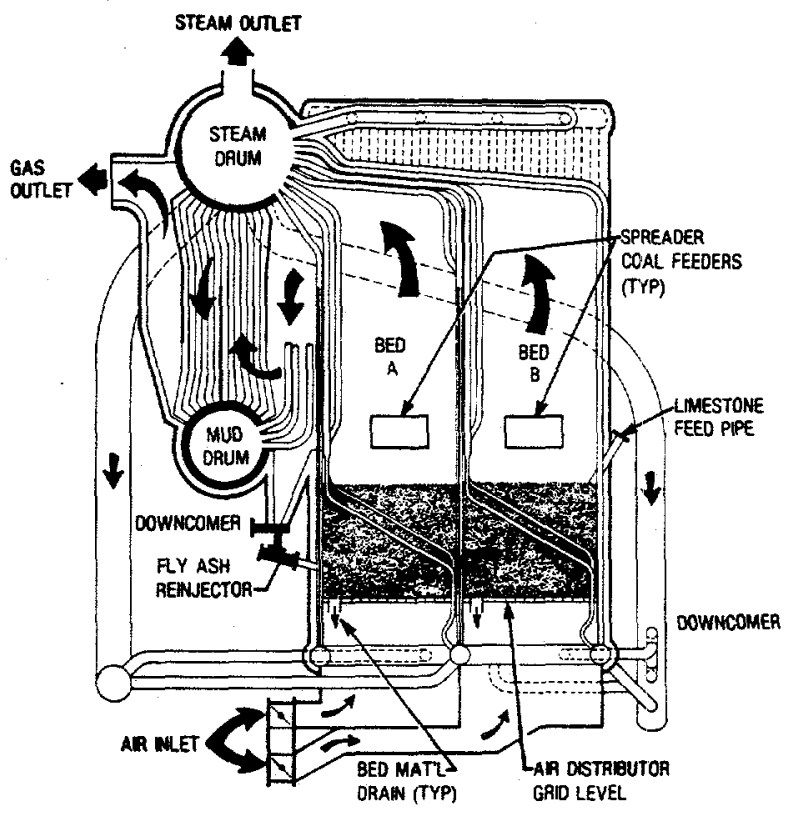

Fig. 1.3-2 Georgetown University steam generator $(12.6 \mathrm{~kg} / \mathrm{s}=$ $100,000 \mathrm{Ib} / \mathrm{hr}$ ) using $\mathrm{AFBC}$; this unit was put into service in 1979 and has operated successfully with fully automatic control. An over-bed coal-feed system [with standard spreader feeder as in stokers using coal smaller than $32 \mathrm{~mm}$ ( 1.25 in.)] and a natural circulation steam flow with balanced draft are used. Reproduced from Gamble. 23 


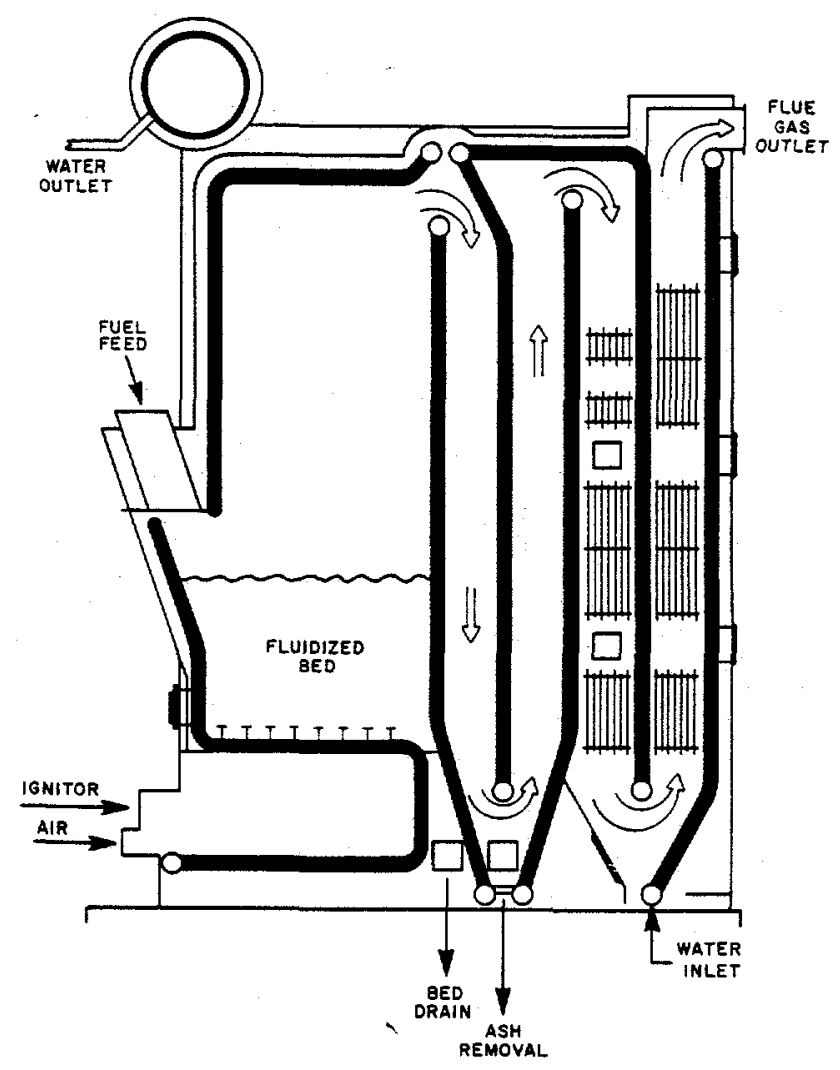

Fig. 1.3-3 City of Eksjo (Sweden) hot-water generator, which normally burns municipal refuse and wood chips in a fluidized bed of sand at an output of $5 \mathrm{MW}_{t}$; with oil firing, the output level is raised to $10 \mathrm{MWt}$. Forced circulation is used for the water flows. Reproduced from Gamble. 23 


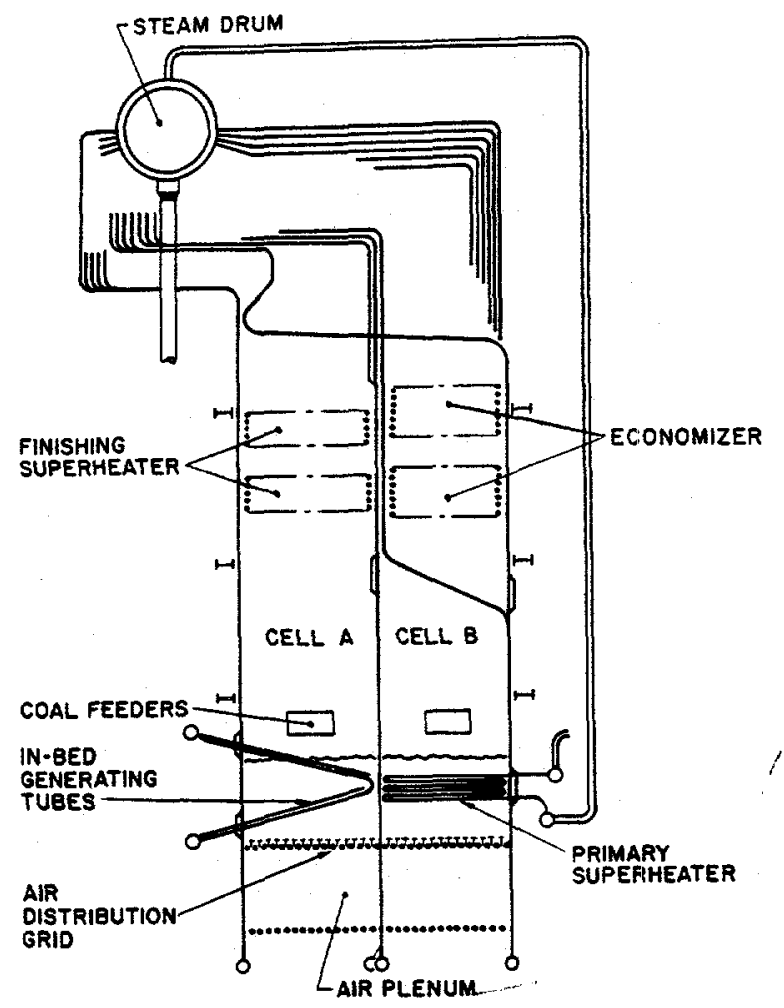

Fig. 1.3-4 Roya1 Dutch She11 (Netherlands) steam generator built by the Foster Wheeler Corporation with startup in 1982. This unit operates on bituminous coal to produce superheated steam for a backpressure turbine generating up to $6 \mathrm{MWe}$ while providing steam for heating an oil-tank farm and associated piping. The over-bed feed system is similar to that used in the Georgetown facility (Fig.1.3-2). Reproduced from Gamble. 23 


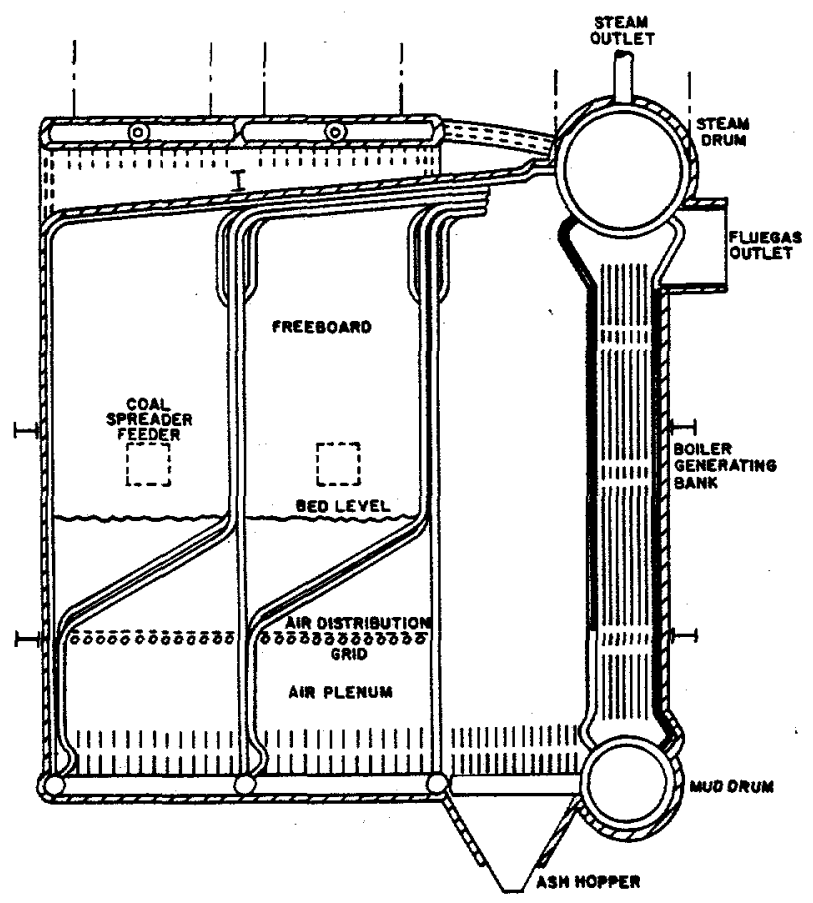

Fig. 1.3-5 Idaho National Energy Laboratory saturated steam generator [Idaho Falis, Idaho $(8.5 \mathrm{~kg} / \mathrm{s}=67,500 \mathrm{lb} / \mathrm{hr})$ ] for heating a nuclear fuel-processing facility (startup is planned for 1984). This unit is similar to the Georgetown AFBC unit, except that space has been provided between the fluidized bed and the boiler intake for the addition of a superheater for cogeneration. Reproduced from Gamble. 23 
Significant improvements in process efficiency have been achieved by increasing the freeboard length above the fluidized bed. $^{22}$ For example, the Rivesville plant (1972) had a 2-ft freeboard length and a combustion efficiency of $88 \%$; a 6 - ft $x$ 6ft section with an 18-ft freeboard showed $94 \%$ combustion efficiency; when recycle was added to this unit, the combustion efficiency exceeded $99 \% .22$ The EPRI AFBC development program on a $6 \mathrm{ft} \times 6 \mathrm{ft}$ bed included tests with bituminous coal containing $4 \%$ of sulfur and lignite with $0.5 \%$ of sulfur. Limestone was added to effect $90 \% \mathrm{SO}_{2}$ removal. Required $\mathrm{Ca} / \mathrm{S}$ ratios were 2.0 for the bituminous coal and 1.5 for the lignite at maximum temperatures of 1550 and $1450^{\circ} \mathrm{F}$, respectively; $\mathrm{NO}_{\mathrm{x}}$ emissions were controlled in both cases at $0.2-0.3 \mathrm{lb}$ per $10^{6}$ Btu while successful operation was achieved with bed-load reductions of $2: 1$, implemented at a rate of $10 \% /$ minute. ${ }^{22}$ These operational characteristics, together with a reduced number of coal-feed points, are scheduled to be implemented by EPRI in a $20 \mathrm{MW}$ pilot at the TVA in Paducah, Kentucky (with demonstration testing scheduled for 1988). ${ }^{22}$ Support studies include the definition of materials suitable for use in the superheater and modeling with predictions of heat transfer and bed dynamics. ${ }^{22}$ A schematic diagram of the $20-\mathrm{MW}$ e facility is shown in Fig. 1.3-6. Load turn-down methods in utility applications include both reductions and redistributions of coal and limestone feed rates. Recycle options include pneumatic injection with solids cooling, forced under-bed injection without cooling, and gravity injection. ${ }^{22}$ A long-range program may involve shop fabrication of $100-\mathrm{MW}_{\mathrm{e}}$ boiler units with barge transport to users, a procedure that could provide access to $200 \mathrm{GW}_{\mathrm{e}}$ of installation capacity representing $93 \%$ of U.S. electrical power demand. The $100-\mathrm{MW}_{\mathrm{e}}$ units may provide turbocharged steam generation (from a boilercyclone-filter-turbocharger sequence) with the advantage of reduced gas-turbine firing temperature, thereby reducing metallurgical demands, simplifying structural design, and allowing reliable 


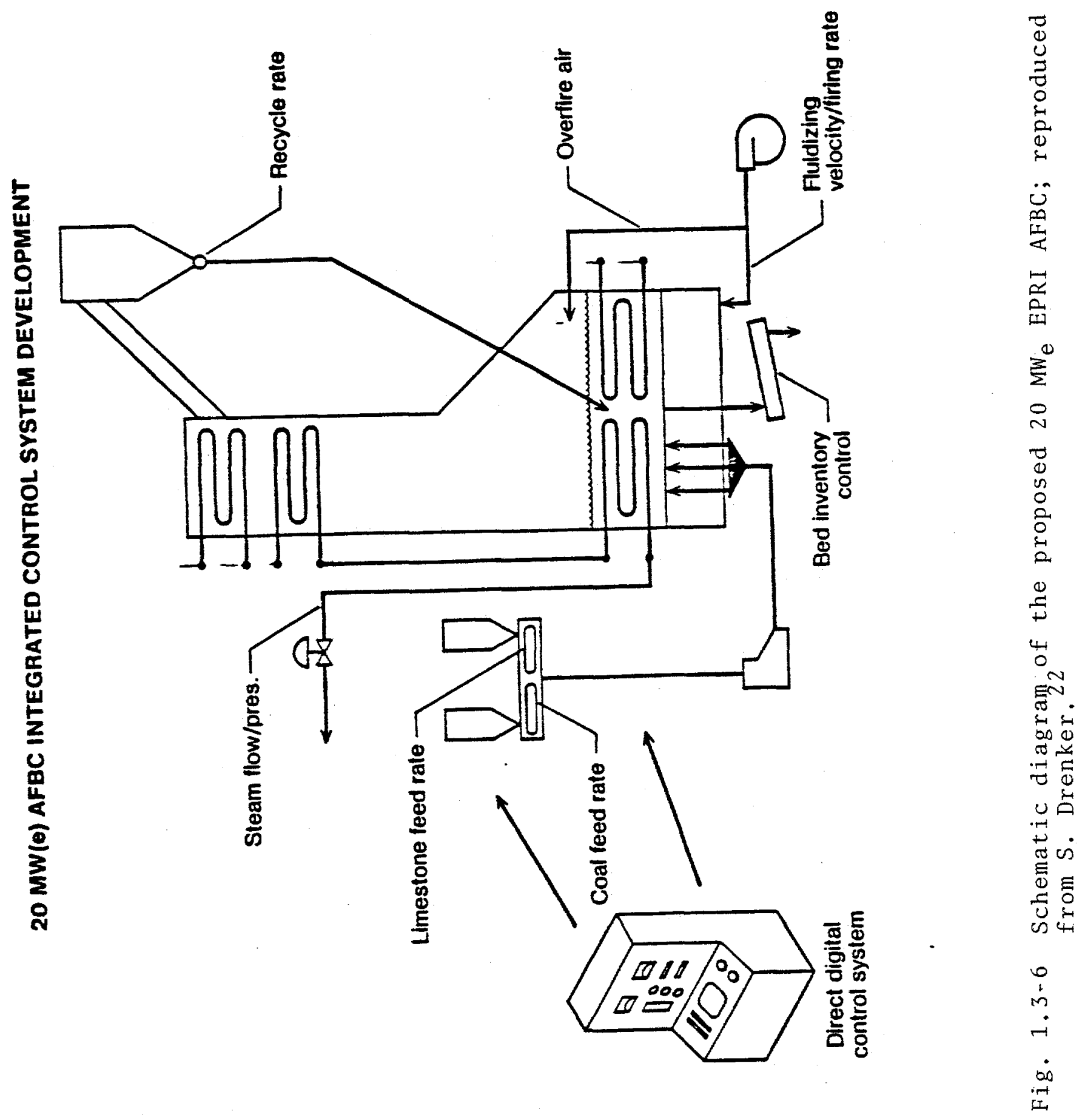


filtration at reduced turbine-generator speed. ${ }^{2}$ Remaining development problems on $A F B C$ deal primarily with combustor performance and reliability.

The Foster wheeler development program ${ }^{24}$ has involved performance and reliability evaluations for 3.5 years on an 18-in. diameter AFBC (see Fig. 1.3-7) and a 20-in. x 20-in. unit (operated for $4.5 \mathrm{yr}$ ).* Both in-bed and over-bed feed systems have been tested with fly-ash recycle and $\mathrm{NO}_{x}$ control (through injection and cleanup with $\mathrm{NH}_{3}$ and staged combustion, which showed that $\mathrm{NO}_{x}$ emis sions were smaller for smaller residual $0_{2}$ levels). ${ }^{24}$ The influence of fuel pelletization has been studied, especially in efforts to simplify the feed system. ${ }^{24}$ Cold-model and subcomponent testing, as well as work on PFBC, have been performed. 24 Cyclone recycle has typically been used.

With in-bed feed, control of surface moisture was required and an excessively large number of feed points was needed (one per 16-25 $\left.\mathrm{ft}^{2}\right) .24$ Fuel distribution to the feed points is difficult to control and small fuel sizes $\left(0.5^{\prime \prime} \mathrm{x} 0\right)$ were required. ${ }^{24}$ With over-bed feed (see Fig. 1.3-2 for an operating unit), larger particles ( $\left.1.25^{\prime \prime} \times 0\right)$ could be handled, the surface moisture problem was absent, addition of water improved combustion efficiency, the required number of feed points was smaller (one per $\left.110 \mathrm{ft}^{2}\right) .^{24}$ There is, however, a tendency for the fluidized bed to malfunction with improper fuel distribution. ${ }^{24}$ Using a spreader-type stoker feeder, the coal throw distance is $6.70 \mathrm{~m} .24$ The use of fly-ash recycle eliminates the necessity for achieving

\footnotetext{
"The following are performance figures for the 20-in. $x$ 20-in. unit: feed rates of $100-500 \mathrm{lb} / \mathrm{hr}$, bed temperatures of $1300-2100^{\circ} \mathrm{F}$, superficial velocities of $4-12 \mathrm{ft} / \mathrm{s}, 1-100 \%$ of excess air, $\mathrm{Ca} / \mathrm{S}$ ratios of 0-20, in-bed and over-bed feeds, fly-ash recycle, and staged combustion. Fuels used include North Dakota lignite, petroleum coke, Irish Arigna coal, anthracite culm, coal and wood waste mixtures, pelletized coal fines, pelletized sludge, and process gas. Combustion efficiencies ranged from 82 to $98+\%$.
} 


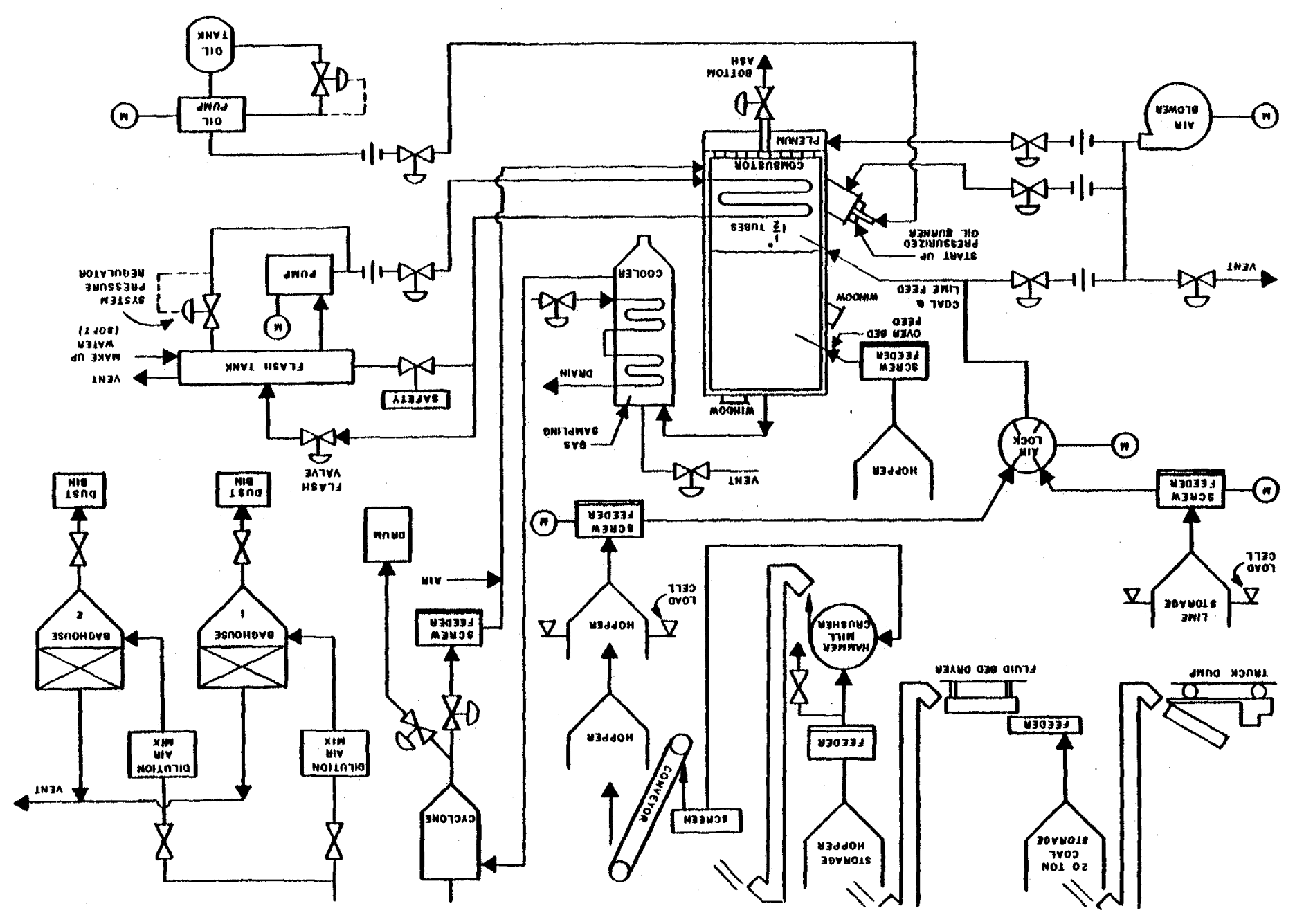

Fig, 1.3-7 Flow diagram for the $20 " x 20 "$ Foster wheeler fluidized bed pilot plant; 
ip in the cell, improves both combustion efficiency pture, and reduces $\mathrm{NO}_{\mathrm{x}}$ emission. ${ }^{24}$ Subcomponent uded work on distribution plates, feeders, fue 1

splitting, pneumatic transport, hot-gas transfer ducts, and the pneumatic classifier. ${ }^{24}$ The air-distribution arrangement was found to be of critical importance. ${ }^{24}$ Two-dimensional, coldflow models were used to study the effects of tubes in the bed. ${ }^{24}$ Extensive operational tests have been performed relating to the influence of the $\mathrm{Ca} / \mathrm{S}$ mole ratio on the percentage of sulfur retained and mole ratios greater than about 3 were found to be necessary in order to effect $90 \%$ sulfur removal. Limestone sulfation is believed to be enhanced by hydration (see. Fig. 1.3-8 for a model of this hydration process).

\subsection{B Preliminary Identification of R\&D Needs}

Identified R\&D needs reflect the operational problems encountered in fluidized bed combustors and include solids handling (including fines), design of the feeding system, heat and mass transfer phenomena, fluidized bed stability and dynamics, reaction kinetics in multiphase flow processes, pollutant controls through in-bed removal techniques, combustion efficiency determinants, modeling, control strategies, etc. ${ }^{25}$ Knowledge gained from catcrackers cannot be applied directly because the particulate sizes involved in FB are generally much (i.e., about a factor of 10) larger. ${ }^{25}$ The importance of the freeboard design on performance has been clearly demonstrated and it is therefore appropriate to consider the sequential and interactive phenomena that couple the fluidized bed to the freeboard. Retrofitting of existing stoker-fired boilers represents a special challenge. The use of cold-flow models as a predictive performance tool requires quantification. 


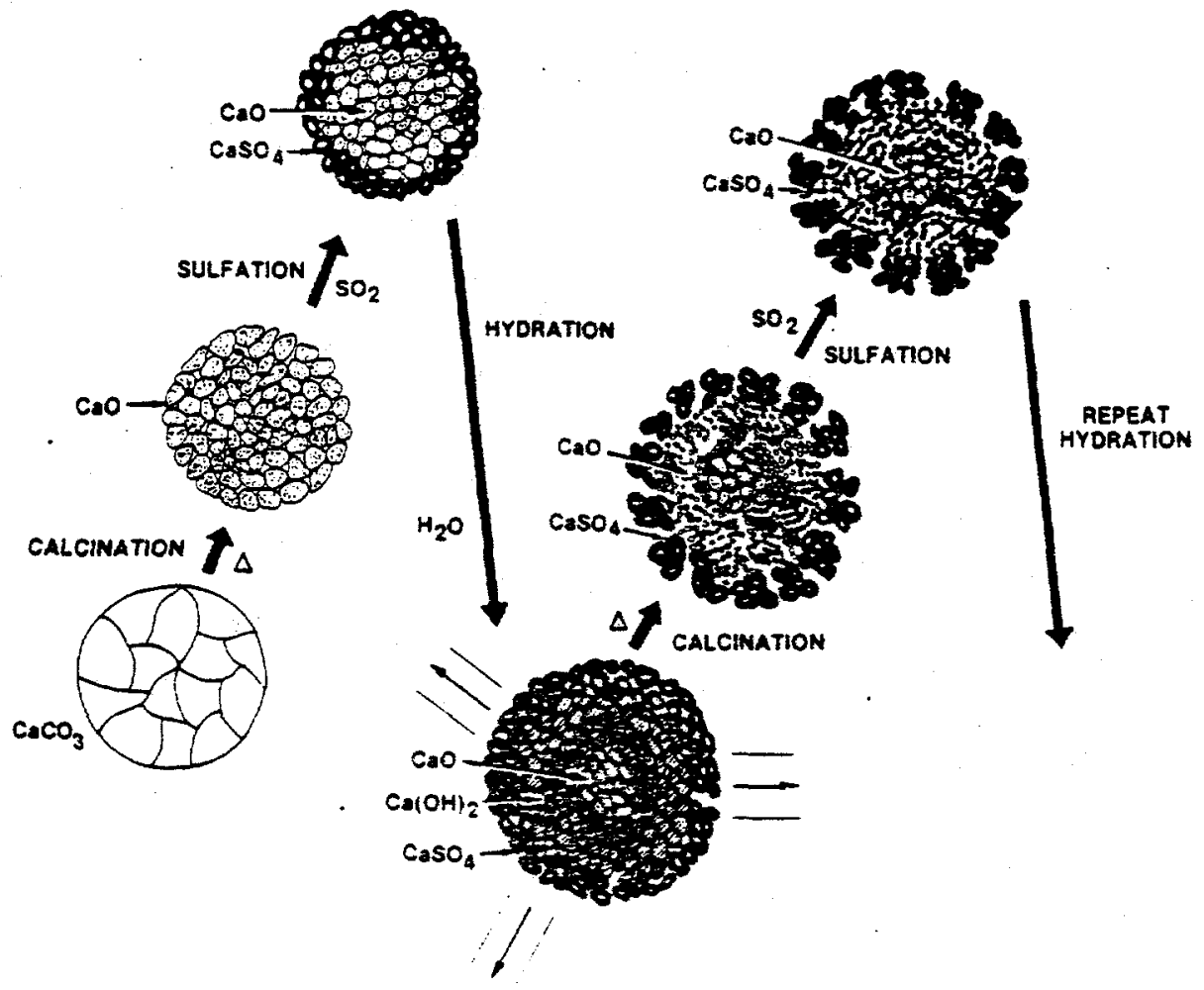

Fig. 1.3-8 Enhancement of limestone sulfation by hydration; reproduced from $W$. Wolowodiuk. 24 
J. M. Beér ${ }^{25}$ has identified the following topical areas as representing research needs relating to the freeboard in AFBC: (i) entrainment of solid particles from the bed and their elutriation from the freeboard, as affected by bed operating conditions and freeboard design parameters; (ii) burn-out of CO, hydrocarbons and of solid carbon particles as affected by freeboard temperature, height and the mode of particle feed; (iii) sulfur capture by sorbent particles entrained from the bed; (iv) reduction of $\mathrm{NO}_{x}$ by $\mathrm{CO}$ and solid carbon along the freeboard height. For the fluidized bed itself, the following research areas were emphasized ${ }^{25}$ (i) movement of particles after injection into the bed or for over-bed feeding; (ii) evolution and combustion of coal volatiles to estimate locally reducing zones and hot spots; (iii)carbon burning as affected by particle swelling, fragmentation, the build-up of ash layers and changing pore structures of the coal char; (iv) the flow near the distributor, bubble size, gas-emulsion exchange coefficients along the bed height; $(v)$, the respective roles of mixing and chemical kinetics in the burn-out of $\mathrm{CO}$ in the bed; (vi) the transient operation of the fluidized bed, including stability limits; (vii) the evolution of fuel-nitrogen from the coal and the formation of $\mathrm{NO}_{\mathrm{x}}$ from volatiles- and char-nitrogen; (viii) the reduction of high $\mathrm{NO}_{x}$ concentrations found experimentally near the coal injection point by reactions between $\mathrm{NO}_{\mathrm{x}}$ and volatile nitrogenous compounds and $\mathrm{NO}_{\mathrm{x}}$ or carbon; (ix) the kinetics of sulfation of $\mathrm{CaO}$, the effects of combustion, and the pore structure of the calcined stone upon sorbent utilization.

From the practical point of view, long-term generation will require adequate control of corrosion and erosion of tubing. 
1.4 Pressurized Fluidized Bed Combustors (PFBCs)

Pressurized fluidized bed combustors are expected to be more efficient than AFBCs. However, it is not clear that they will be more economical in terms of power-generation capability (see Appendix AB-8, especially the DOE Design Study of Advanced Fossil-Fuel Systems, DAFFS). Heat rates have been estimated at 8470 for $P F B C, 9640$ for $A F B C$, and 9860 for conventional pulverized coal burners (with improvements possible to 8200 ). The corresponding electricity costs (levelized for 1981-2000 in mills $/ \mathrm{kW}_{\mathrm{e}}-\mathrm{hr}$ ) are 74,77 , and 86 (perhaps ultimately 67), respectively. 22 The $P F B C$ may be attractive for applications in combined cycle operations. A conceptual design of this idea is shown in Fig. 1.4-1.

\subsection{A Past and Current Developments}

Viewgraphs providing an excellent overview by A. Robertson 26 of the development of pressurized fluidized bed combustors are reproduced in Appendix AB-9. These viewgraphs cover the following topics: advantages of $\mathrm{PFB}$ operations over conventional PC combustors, PFB combined cycles (air-cooled PFB and water-/steamcooled PFB), overall plant efficiency vs. compressor pressure ratio for various turbine-inlet temperatures, the CURL/Leatherhead $P F B$ and 1972-73 test results, the Exxon PFB miniplant cooling coil after 1200 hours of operation, $\mathrm{SO}_{2}$ retention vs. $\mathrm{Ca} / \mathrm{S}$ mole ratio in miniplant dolomite tests for contact times between 0.5 and $3.0 \mathrm{sec}, \mathrm{NO}_{\mathrm{x}}$ emission (in $\mathrm{g} / \mathrm{Mj}$ or $\mathrm{Ib} / \mathrm{MM} \mathrm{BTU}$ ) vs.\% of excess air, combustion efficiency vs. average temperature in Exxon tests, CFCC tube bundle configuration at NCB-CURL for $16.8 \%$ packing density, heat-transfer coefficients vs. height above the distributor in immersed tubes in a $9-\mathrm{ft}$ bed at 1420 and $1620-1640^{\circ} \mathrm{F}$, freeboard heat-transfer coefficients vs. height above the bed surface, factors affecting turbine expander life, Sta-Laval and GE cascades used in turbine tests, cyclone configurations and test data for particulate removal in PFBC at Exxon and CURL, schematic diagram of a 170 MW PFB demonstration plant, 
PRESSURIZED FLUIDIZED-BED COMBINED CYCLE

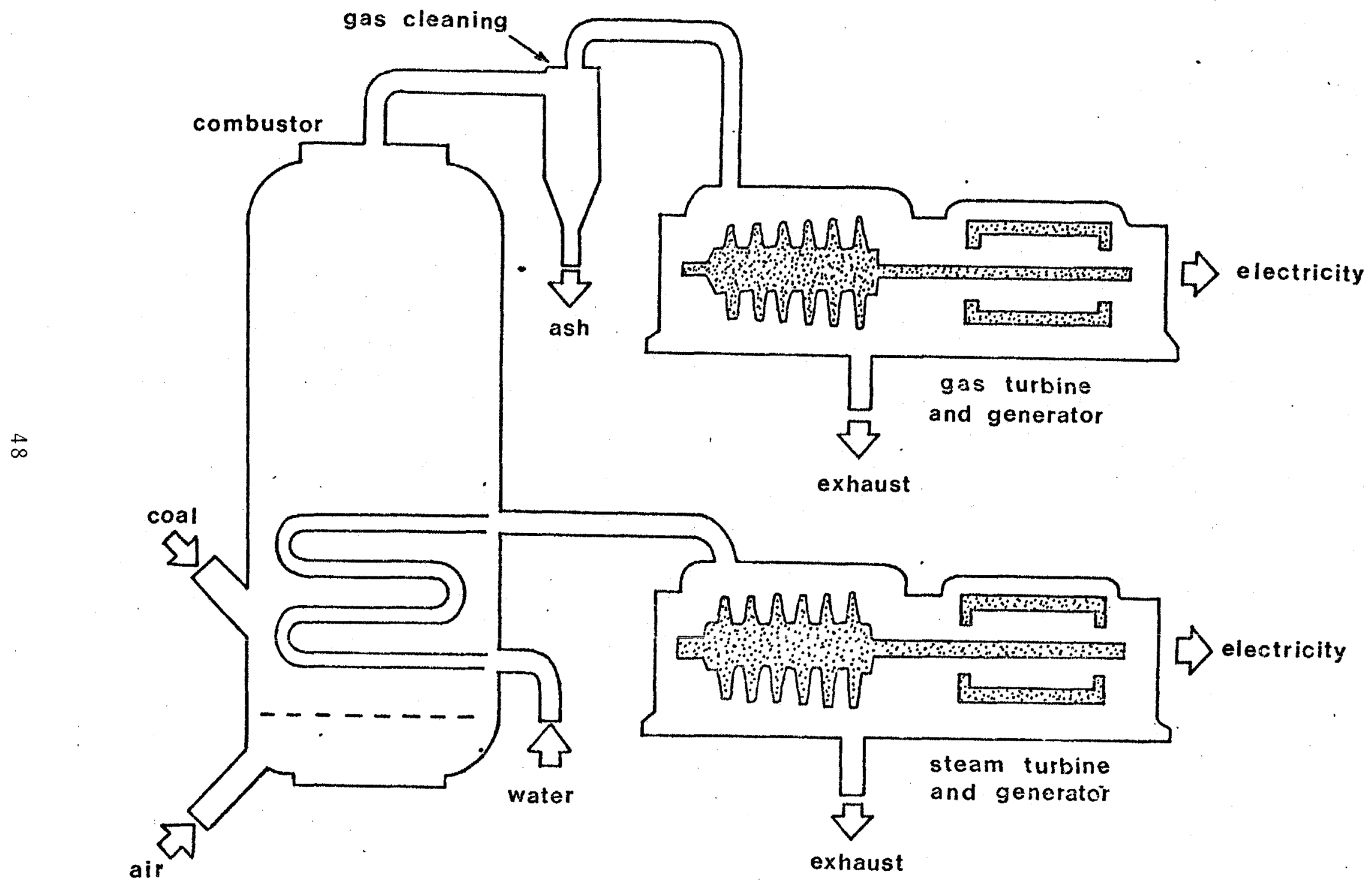

SOURCE: NATIONAL COAL BOARD

Fig. 1.4-1 Schematic diagram of a combined cycle PFBC; reproduced from S. Drenker. ${ }^{22}$ 
catcracker and PFB comparisons, low-risk PFB cycles, schematic diagrams of a contained 250 MW PFB steam generator and a superheater reheater, PFB barge shipments of shop-assembled $125 \mathrm{MW}$ units, test results obtained with the Grimethorpe PFB and at CURL/Leatherhead, notes on hot-gas cleanup.

A comprehensive overview of the Curtiss-Wright pilot plant development, 27 as well as work on more fundamental PFB coalcombustion program at $N Y,^{28}$ are also summarized in Appendix $\mathrm{AB}-9$.

Construction of the Curtiss-Wright pilot plant follows extensive experience (i.e., over 10,000 hrs of operation with one-third of allowable $\mathrm{NO}_{\mathrm{x}}$ and $\mathrm{SO}_{2}$ production, as well as excellent durability for the in-bed heat exchanger and turbineblade materials) with a smal1-scale model. The pilot plant is currently under construction and is expected to be operational by the fall of 1983. The equivalent electric power output of the plant should be somewhat more than $13 \mathrm{MW}_{\mathrm{e}}$. The plant will have an industrial gas turbine with an air-flow capacity of $1201 \mathrm{~b} /$ sec and a 7:1 compressor pressure ratio. The power turbine will be gas-coupled to a gas generator and will be mechanically coupled to a gearbox and generator producing $7 \mathrm{MWe}$. The gas will leave the power turbine through a bifurcated duct and enter a waste-recovery boiler producing a steam-flow rate of 58,000 1b/ hr. This pilot plant is viewed as about a one-sixth scale version of a commercial module to be used in a $500 \mathrm{MW}$ combined cycle plant. The emphasis in this work is on the production of electric power and steam using high-sulfur coal under environmentally acceptable conditions. Good descriptions of these developments are given in Refs. 27 and 29.

Zakkay ${ }^{28}$ and his colleagues have operated a PFBC for research since 1975. A new facility has been operational since early July 1982 and consists of a 30-inch i.d. burner operating at 1 to $10 \mathrm{~atm}, 1300-1400^{\circ} \mathrm{F}$, with coal throughputs of 0.5 to $1.5 \mathrm{t} / \mathrm{hr}$. Shakedown tests have been run with bituminous coals 
(supplied as ground coals at $-1 / 8^{\prime \prime}$ in barrels by Curtiss-Wright at a cost of $\sim \$ 500 / t)$, although most of the research will be concerned with North Dakota 1ignites. Combustion efficiencies generally exceed $99 \%$ and less than 100 ppm of $\mathrm{NO}_{x}$ are emitted. The primary emphasis has been on combustor design and control and on effluent clean-up. Current activities include the design of a novel three-stage fluidized bed reactor, with the first stage carrying relatively large coal particles confined by grids in a circulating combustor. Heat exchangers are located in the second stage, and an elutriator for particulate removal serves as the third stage. The design appears to be especially well suited for studies of the elementary sequential processes that occur in fluidized bed combustors.

Materials studies performed at EPRI have shown that FeCrA1Y may be used to reduce or eliminate erosion and corrosion by the PFBC dust. Experiments have been performed at various scales: at Exxon, with a coal-feed rate of $0.14 \mathrm{t} / \mathrm{hr}$ in a test facility with $0.8 \mathrm{ft}^{2}$ bed area and $1.0 \mathrm{ft}$ diameter; at the National Coal Board in the UK, with $6 \mathrm{ft}^{2}$ bed area, $2 \mathrm{ft} \times 3 \mathrm{ft}$ bed lengths, $0.5 \mathrm{t} / \mathrm{hr}$ coal feed rate, $5 \mathrm{~atm}$ pressure. Current IEA-sponsored work is in progress at the Grimethorpe test facility in the UK ( $25 \mathrm{MW}_{\mathrm{e}}, 10 \mathrm{~atm}, 1000$ hours of operation have been completed, $42.9 \mathrm{ft}^{2}$ bed area, $6.5 \mathrm{ft} \times 6.5 \mathrm{ft}$ dimensions, $10 \mathrm{t} / \mathrm{hr}$ of coal). A $100-\mathrm{MW}$ e prototype is being designed.

\subsection{B RGD Recommendations on PFBCs}

Research needs in PFBC are analogous to those 1 isted for $A F B C$, except that they refer to elevated pressure levels. A summary of technical uncertainties relating particularly to PFBCs is reproduced in Table 1.4-1. This listing should be modified by noting (a) that studies of depositions on turbines are viewed by some as of relatively low priority and (b) extensive further work must be done to improve our understanding of the fluid mechanics and combustion properties in PFBCs, including fuel dispersion from feed points, combustion chemistry, 
calcination and sulfur retention, and freeboard processes.

The summaries of AFBC research needs given by Shang, Beêr, and others ${ }^{25}$ may be readily transcribed to PFBCs since the design requirements and program objectives are analogous, except that operations at elevated pressures are involved. The required minimum levels of understanding must be commensurate with the needs for modeling to assure adequate process control and to allow scaling of plant sizes without incurring undue delays and costs. In this connection, it is apparent that considerable expansion is desirable in the use of non-intrusive diagnostic techniques to define quantitatively such parameters as rates of volatilization, CO burn-out, fuel-nitrogen reactions, production rates of $\mathrm{SO}_{2}$ and $\mathrm{NO}_{x}$, as well as bed-stability regimes, turbulent heat-transfer rates, and other fluid-dynamic parameters.

Table 1.4-1 A summary of identified research needs relating to PFBCs; reproduced from Zakkay. 28

1. Hot-gas cleanup and its relation to turbine performance, with emphasis on the following problem areas:

(a) turbine erosion,

(b) depositions in turbines,

(c) the effects of alkali metals and sulfur oxides on turbine erosion and depositions.

2. Materials development to reduce problems resulting from erosion and increase operating reliability.

3. Sulfur retention should be studied as a function of pressure leve1.

4. Performance experience is needed with diverse run-ofmine coals.

Practically important problem areas include load-following capability and long-term operations at elevated temperatures and pressures.

1.5 Advanced (Developing) Coal-Combustor Designs and CoalCombustion Applications

Current work includes a number of interesting, often relatively small-scale, programs, which deal with novel coal combustor designs or applications. One or more of these may turn out to 
have sufficient merit for future commercialization on substantial scales. Detailed descriptions of several proposed application techniques, as well as the current status of these studies, are presented in, the appendices to our site-visit reports. Here, we comment briefly on several of these designs.

\subsection{A The Battelle Multisolids Fluidized Bed Combustor (MSFBC)}

The MSFBC (see Figs. 1.5-1 and 1.5-2) is described in Appendix $A B-9$ and was developed after testing in a $0.5 \times 10^{6} \mathrm{Btu} / \mathrm{hr}$ research facility. It is a variant of the AFBC and is currently being modified to operate at elevated pressures in order to achieve a more compact design. The atmospheric pressure version of the MSFBC is 1icensed for commercial use. Pressurization is expected to change fluidization behavior, two-phase mixing in the entrained region, and the spatial concentration of the carbon phase. A modeling program is being used and improved in conjunction with the new applications of the MSFBC.

\subsection{B SIagging Combustors}

Slagging combustors are currently under development. These reactors are applications of technologies developed in the $1940 \mathrm{~s}$ and $50 \mathrm{~s}$ in the U.S. and Europe and more recently in connection with the U.S. and U.K. programs on MHD power generation.

A schematic diagram of the AVCO-Everett combustion-chamber design is reproduced in Fig. 1.5-3. Combustors of this type are expected to accept most coal types and to produce minimal ash carryover. 30 A good deal of understanding concerning coal properties and combustion has been derived from the MHD applications. The pulverized coal is exposed to air at about $2000^{\circ} \mathrm{F}$, which leads to hypergolic ignition. A combustion model has been developed for these operating conditions and involves a two-step pyrolysis reaction that is followed by oxygen attack

on char. Successful predictions have been achieved of flame stability and flame extinction. The combustor developed for MHD applications produced slag layers. The development and time histories of these slag layers could be approximated by 

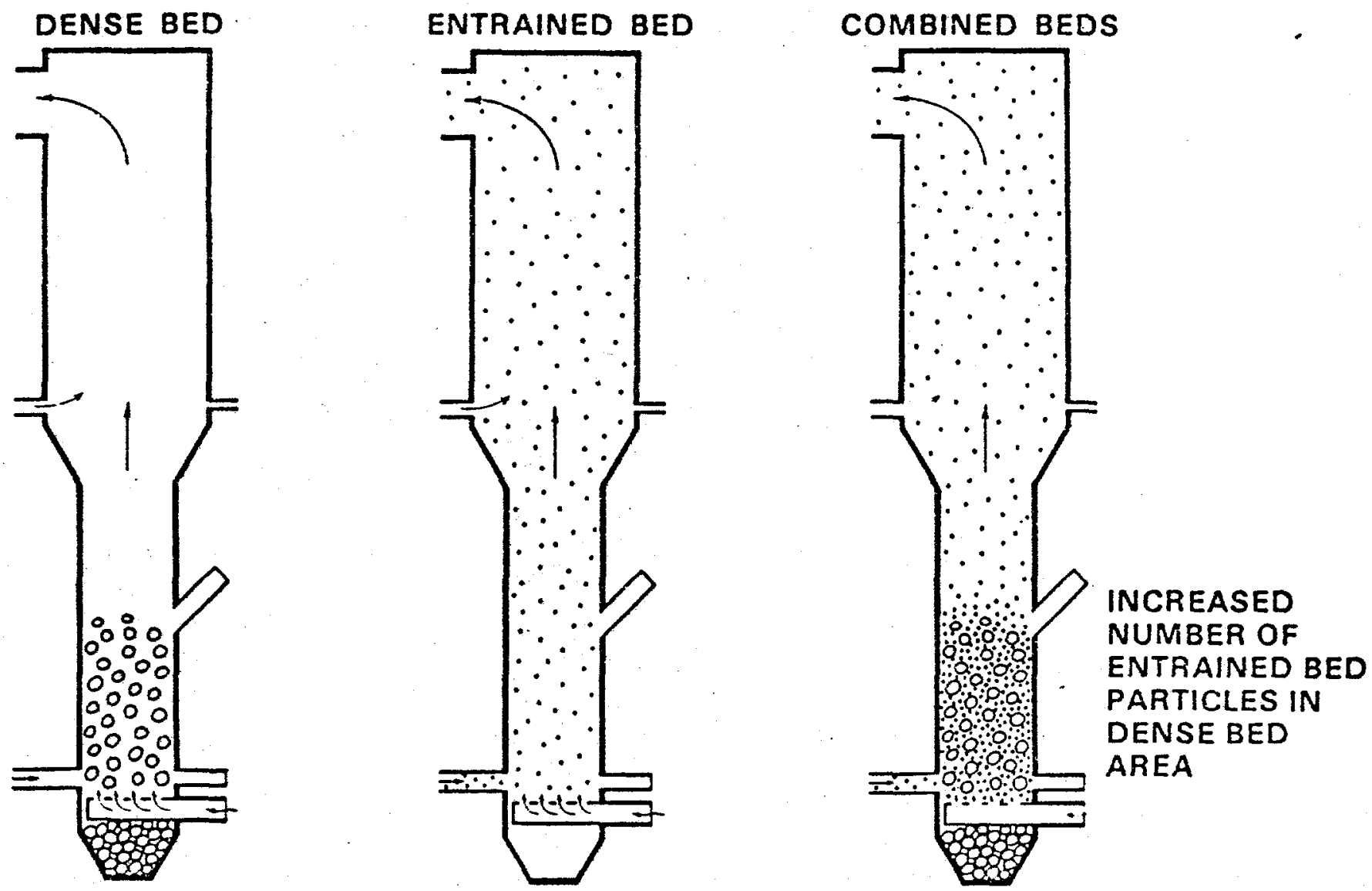

Fig. 1.5-1 The Battelle multisolid fluidized-bed combustor, depicted in three operating modes; reproduced from $H$. Nack in Appendix $A B-9-4$. 


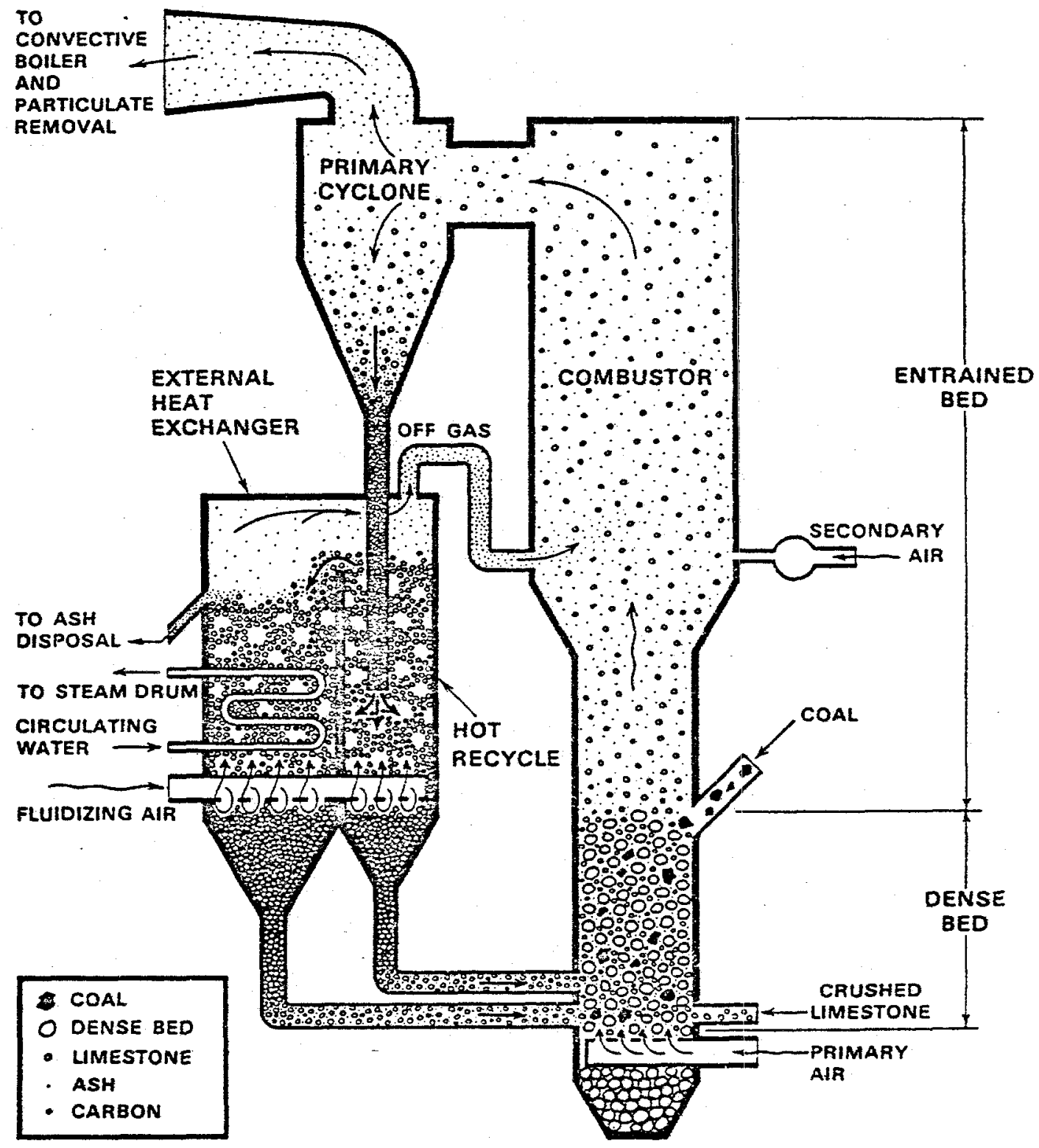

Fig. 1.5-2 Schematic diagram showing operational components of the Battelle multisolid fluidized-bed combustor; reproduced from $H$. Nack in Appendix AB-9-4. 


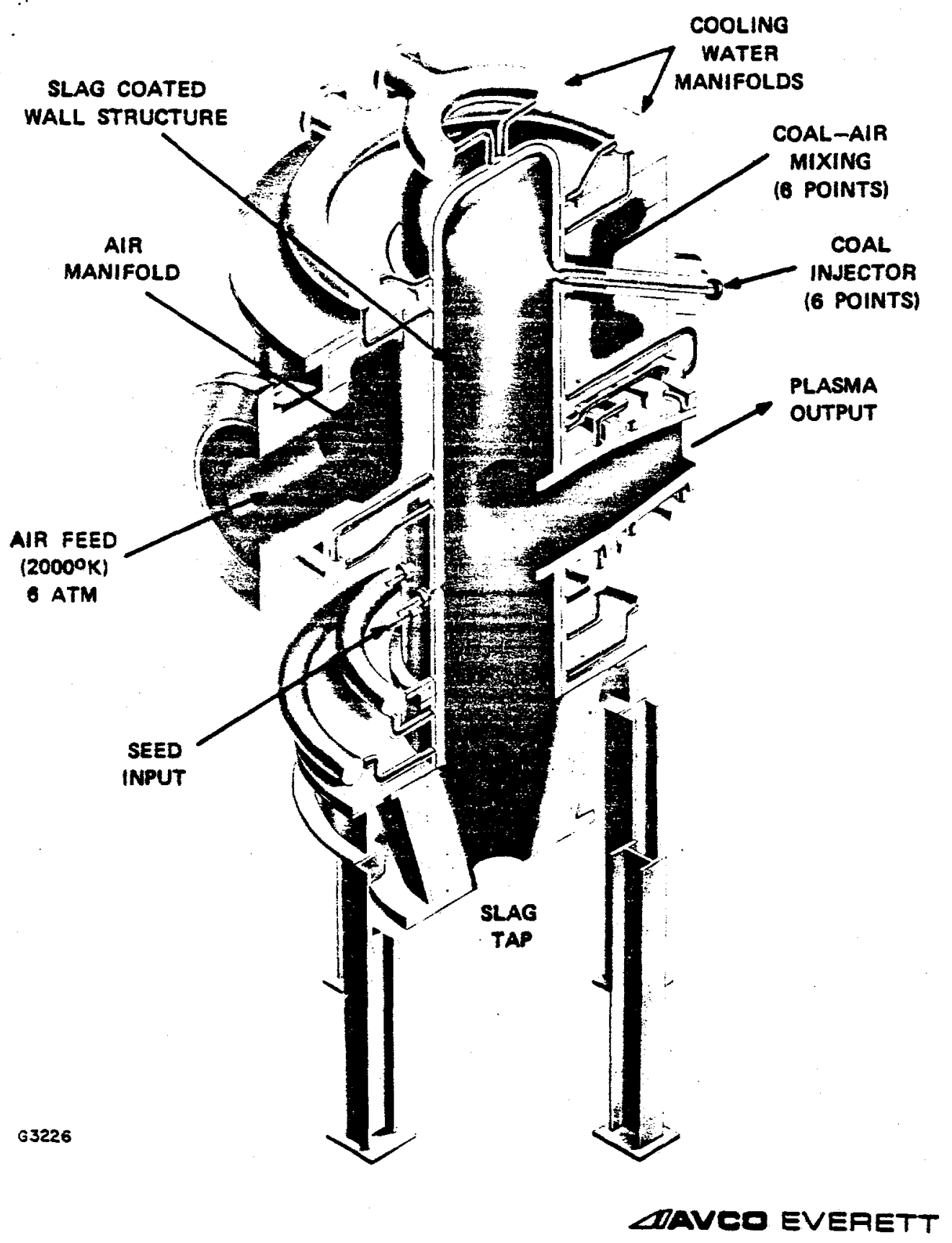

Fig. 1.5-3 Schematic diagram showing the combustion-chamber design used in the AVCO-Everett slagging combustor for MHD power generation. 30 Without seed input, this unit becomes a slagging coal combustor operating at temperatures between about 2500 and $4600^{\circ} \mathrm{F}$ and at pressures in the range of 4 to 6 atmospheres; reproduced from D. B. Stickler, Appendix AB-9-6. 
utilizing analytical procedures that are analogous to those employed for heat transfer and melting of reentry heat shields.

During December of 1982, a successful demonstration of a slagging, two-stage, coal-fired MHD electric power generator (simulating a $20 \mathrm{MW}_{\mathrm{e}}$ unit) was accomplished under DOE sponsorship in a joint AVCO-TRW program. A steady power output of 200 $\mathrm{kW}_{e}$, a peak power of $250 \mathrm{~kW}_{e}$, slag recovery of $70 \%$, and carbon burnout of $99.9 \%$ were achieved.

An entrained, slagging combustor is also under development at TRW for applications in MHD power conversion $[6$ atm. pressure, $\mathrm{T}_{\text {oxidizer }}>2500^{\circ} \mathrm{F}$, the oxidizer is oxygen-enriched air, and the equivalence ratio ( $\phi)$ ranges from 0.5 to 0.7$]$, in low-Btu gasifiers ( 4 to $25 \mathrm{~atm}$, pure $\mathrm{O}_{2}, \phi=0.4$ ), and in retrofits for industrial and utility boilers ( $1 \mathrm{~atm}, \mathrm{~T}_{\text {oxidizer }}=750^{\circ} \mathrm{F}$, air is used as oxidizer). 31 For the third application, tests have been conducted in a 17 in. combustor at about the $3-\mathrm{MW}_{\mathrm{t}}$ leve1. About 350 hrs. of operation were completed. It is expected that the TRW combustor will be interposed between the coal-inlet section and the existing (oil-firing) boiler in retrofits for conversion to the use of PC or CWM. The slagging operation will be developed to remove about $90 \%$ of the coal ash. Scale-up to a 34 in. i.d. unit $\left(50 \times 10^{6} \mathrm{Btu} / \mathrm{hr}\right)$ is being proposed. A $10 \times 10^{6} \mathrm{Btu} / \mathrm{hr}$ burner is currently in operation at TRW's Capistrano Beach facility.

\subsection{Gas-Turbine App1ications 32}

Extensive studies have been performed at the General Electric Company (GE) on the use of high-ash fuels (residuals) in gas turbines. Erosion, corrosion, and depositions (ash fouling) were observed primarily in the turbine nozzles. With residual oils, the primary operational problems result from the presence of vanadium. This element is not readily removed from residual oils but is generally not an important constituent of coals. Experimental studies have been performed with $\mathrm{Mg}$-addition (at a weight ratio about 3 times that required for a stoichiometric mixture) to remove the $V$. An ash deposit is observed on the nozzles and blades after prolonged operation (i.e., 
several hundred hours), which can be removed by "nutshel1ing" (i.e., temporary injection of crushed walnut shells at a mass ratio of about 0.5 of that of fuel). A substantial data base has been accumulated on the operation of high-ash residual fuels in gas turbines. The principal design features and problem areas are sketched in Fig. 1.5-4.

Destructive compressor surges result from plugging of the first-stage nozzle. The use of higher temperatures to eliminate plugging of the first-stage nozzle tends to move the operational problems to the first-stage rotor and further downstream.

The extent of wall deposition is primarily determined by the wall temperature. Extensive simulation experiments on wall deposition have been performed by inserting an air-cooled, flat plate in a 3-in. ${ }^{2}$ test section and measuring deposit formation from a number 2 fuel oil to which dopants had been added to simulate high-ash resids. The data in Table 1.5-1 indicate the importance of local temperature. Experimental studies were performed on carefully modeled nozzles with four vanes. The flow speed was sonic at the throat while operating with pressure ratios of 2 to 1 . An effective nozzle area was obtained as a function of time by determining the percentage of nozzle blockage per 100 hours of operation. Tolerable blockage in industrial applications is up to about $5 \%$ of area (corresponding to a $10 \%$ power 1oss). The observed deposit thickness was not simply related to an effective throat restriction. Instead, an effective area parameter has been used to characterize nozzle plugging.

An METC program at GE and at Westinghouse deals with CWM. A prior, EPRI-funded program was pursued during 1979-80 on a water-cooled turbine at GE. This engine will probably be used with CWM. Engine cleanability has been found to be better with water-cooled than with air-cooled engines.

1.5D Integrated Coal Gasification Gas Turbine Combined cycle (IGCC) system

IGCC systems may be cost-effective in utility applications. A useful 1981 evaluation of this concept is given in Ref. 33a. 


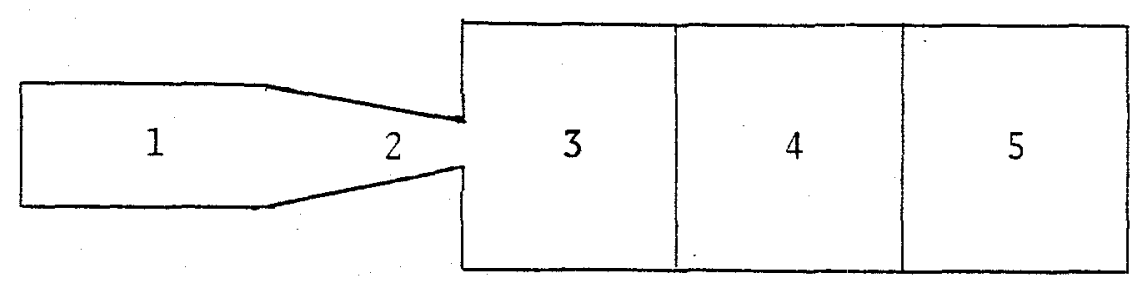

Fig. 1.5-4 Schematic diagram showing operation of a gas turbine with high-ash resids; 1 , combustor operating at about $4000^{\circ} \mathrm{F}$ with the formation of particulates; 2 , transition piece which yields exit temperatures of about $2000^{\circ} \mathrm{F}$ and allows particle growths by condensation and agglomeration; 3 , first-stage nozzle where deposition occurs by impaction and condensation; 4, first-stage rotor; 5, subsequent turbine stages; reproduced from D. B. Smith and described in Appendix AB-5.1.

Table 1.5-1 Deposit formation ratios observed in simulation tests with number 2 fuel oil containing dopants; reproduced from D. B. Smith and described in Appendix AB-5.1.

\begin{tabular}{|l|c|c|}
\hline \multicolumn{1}{|c|}{ Atomic weight ratios } & $\mathrm{Mg} \div \mathrm{V}$ & $\mathrm{Na} \div \mathrm{V}$ \\
\hline Measured atomic weight ratios & 10.6 & 3.2 \\
\hline $\begin{array}{l}\text { Calculated equilibrium atomic weight } \\
\text { ratios at the equilibrium gas temperature }\end{array}$ & 7.14 & 2.3 \\
\hline $\begin{array}{l}\text { Calculated atomic weight ratios at equili- } \\
\text { brium for the measured local wall tempera- } \\
\text { ture, after prior equilibration at the } \\
\text { equilibrium gas temperature }\end{array}$ & 11.4 & 3.4 \\
\hline
\end{tabular}


In combined-cycle operation, both gas and steam turbines are used (see Fig. 1.5-5). These coupled systems provide higher fuel-energy-to-electricity conversion efficiencies than is achieved with either steam turbines (which have traditionally been used for base-load capacities in unit sizes up to about $1200 \mathrm{MW}_{\mathrm{e}}$ ) or with gas turbines (which have been used preferentially for load topping at unit sizes less than $75 \mathrm{MW}_{\mathrm{e}}$ ). ${ }^{33 \mathrm{~b}}$ For direct application of coals as fuels in combined-cycle operations, we expect to obtain also emission controls at reduced costs and operations with lower water consumption. Coals are generally first gasified to mixtures of $\mathrm{CO}$ and $\mathrm{H}_{2}$, which then serve as input fuels. In this conversion mode, the combined-cycle for electricity production operates downstream of a coal-gasification unit. Coal gasification is not a component of the studies assigned to CCAWG but has been examined in an antecedent investigation by the DOE Fossil Energy Research Working Group.

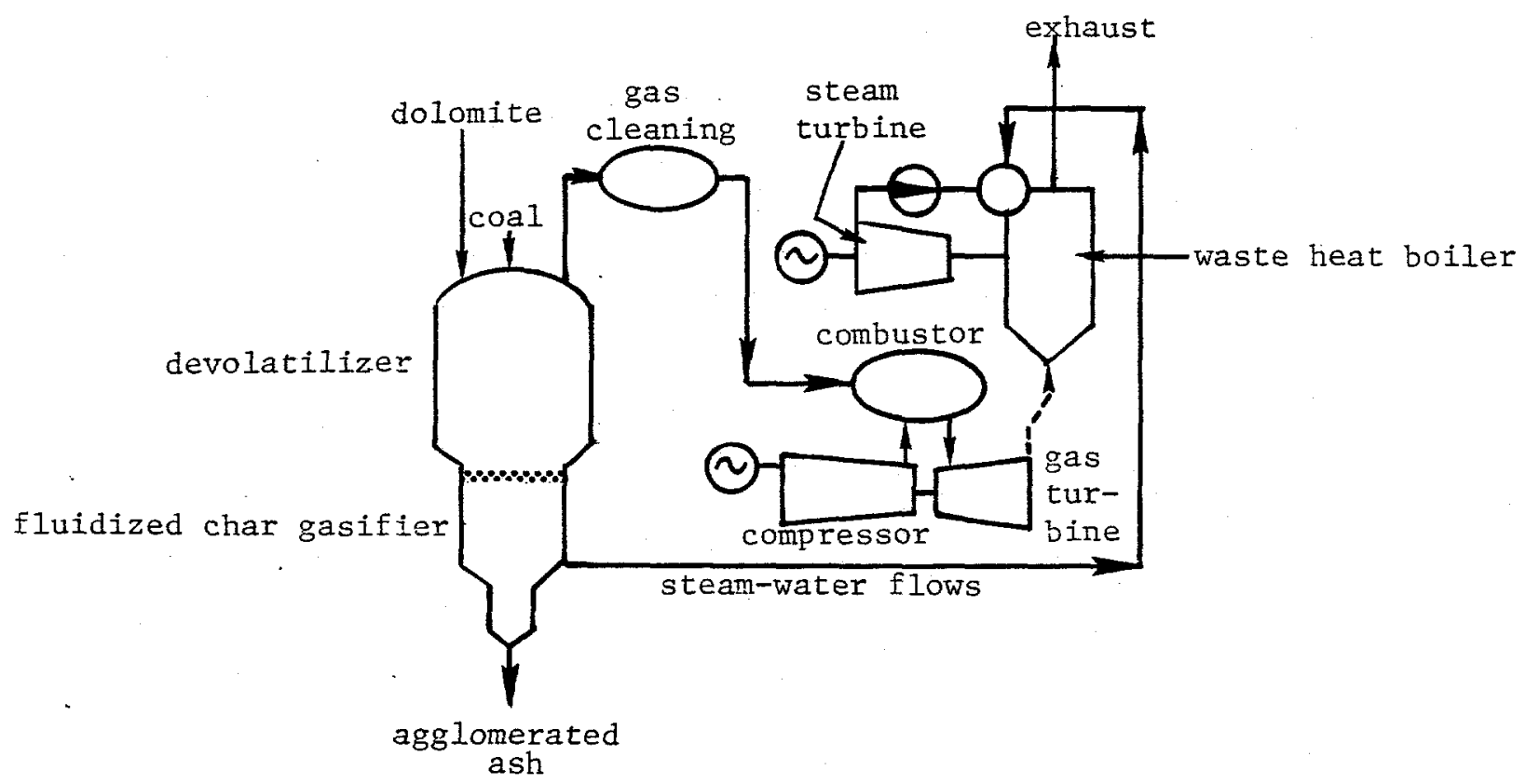

Fig. 1.5-5 Schematic diagram of the Westinghouse integrated coal gasification, combined-cycle system. 


\subsection{Coal Quality and Clean-Up}

Coal quality and coal clean-up have become major factors, both for utility and industrial applications of coals. The emphasis on coal quality is the result of declining efficiencies and reliabilities in coal-burning facilities. Efficient and reliable coal-utilization equipment, with low sensitivity to different types of run-of-mine coal sources, has been identified as a primary operating goal by coal users.

It is apparent that the problem area identified in the preceding paragraph poses major challenges to the coal scientists, the combustion experts, and the plant engineers. Significant advances will require levels of understanding substantially beyond those which we have at present. Yeager 34 has posed the problem well by noting that we must (a) understand "the quality and variability of coal likely to be used over the life of the plant, (b) evaluate the effect of coal quality on power-plant design and capital cost, (c) evaluate the effect of coal quality on plant performance and availability, and (d) establish appropriate coal-quality specifications" for particular power-plant designs. The programmatic implications of these goals include quantitative cost-assessments of trade-offs. Here, we note a number of recent developments that have important bearing on these issues.

\subsection{A Analyses and Diagnostics}

Quality assessments require analyses and diagnostics. Prompt neutron activation of $\gamma$-ray emissions as a function of frequency, using Californian-252 as radiation source, has emerged as a promising technique for quantitative measurements of the element concentrations that are present in coals. The application program is known as CONAC (for Continuous Nuclear Analysis of Coal) and has been utilized, for example, in a continuous sulfur analyzer at the Detroit Edison Co. (1981) and as a batch sulfur analyzer at the TVA. ${ }^{34}$ Complete, on-1ine concentration determinations for all of the elements have also begun at the TVA. ${ }^{34}$ It is apparent that applications of this 
measurement technique will provide useful information on such processes as coal blending, washing, beneficiation, slag management and fouling, etc. It is also apparent that this useful technique is inadequate for the required, more complete characterization of coals that must be implemented to achieve the identified programmatic goals.

There are many new and powerful diagnostic techniques that can be applied to each stage of the coal-conversion processes. For example, in the combustor, diffusion-broadening laser spectroscopy can be used to characterize small particle-size distributions, coherent anti-stokes Raman scattering has been shown to be a useful tool in following combustion processes, powerful new techniques of organic chemistry may be applied to elucidate the unit and repeating structures in coal sources, laser-scattering techniques are the diagnostic tools of choice in monitoring effluent compositions without sampling, etc.

\subsection{B Coal Beneficiation}

Both conventional and new methods for coal cleaning have been evaluated in a recently published book. 35 This topic was reviewed by S. P. N. Singh. 36 Singh's cost summary is reproduced in Table 1.6-1. These techniques are not yet commercially viable (compare Table 1.6-1) since the economic value of removing the necessity for post-combustion $\mathrm{SO}_{\mathrm{X}}$ removal is about $\$ 6 / t$ and increased reliability in utility operation is equivalent to savings of about $\$ 1 / t$. It is, however, apparent that research on improved beneficiation techniques is needed and that coal beneficiation represents an integral component of programs leading to possible commercialization of coal slurries, as well as of the design and development of more efficient and reliable direct coal-utilization techniques.

Among potentially interesting procedures for coal cleaning that are not covered in Ref. 35, we note the TRW Gravime1t Process. This procedure has been developed by $R$. A. Meyers and his associates. 37 In the Gravimelt Process, fused caustics are 
Table 1.6-1 Comparison of the material recoveries and beneficiation costs for the five conceptual coal beneficiation processes (second-quarter 1978 costs); reproduced from S. P. N. Singh, Appendix $\mathrm{AB}-9-6$.

\begin{tabular}{|c|c|c|c|c|}
\hline \multirow[b]{2}{*}{ Process } & \multirow{2}{*}{$\begin{array}{l}\text { Material } \\
\text { re covery } \\
(\%)\end{array}$} & \multirow{2}{*}{$\begin{array}{l}\text { Beneficlation cost } \\
\text { per ton coal } \\
\text { processed, } b, c \\
(\$ / \text { ton })\end{array}$} & \multicolumn{2}{|c|}{$\begin{array}{l}\text { Incremental cost over wet } \\
\text { mechanical beneficlation }\end{array}$} \\
\hline & & & $\begin{array}{l}\text { Leve } 12 \\
(\$ / \text { ton })\end{array}$ & $\begin{array}{l}\text { Leve } 14 \\
(\$ / \text { ton })\end{array}$ \\
\hline Wet magnetic beneficlation & 85 & 20.42 & 13.17 & 10.12 \\
\hline Chemical comminution & 89 & 14.46 & 7.21 & 4.16 \\
\hline Meyers process & 86 & 28.23 & 20.98 & 17.93 \\
\hline Leve 12 wet mechantcal & 72 & 7.25 & & -3.05 \\
\hline Leve 14 wet mechanlcal & 74 & 10.30 & 3.05 & \\
\hline
\end{tabular}

aperived as tons of cleaned product coal per ton of ROM coal feed. $\% / 100$.

berived as (product price per ton - feed coal cost per ton of product coal) $x$ material recovery,

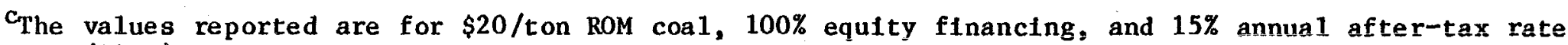
of return (AARR) on equity. 
used for sulfur removal. Bench-scale tests ( 5 lbs of coal/hr) have been performed, although not for sufficiently long periods of time to reach steady-state conditions. The beneficiated coal has not yet been used in combustion tests. Caustic regeneration requires about one half of the total cost, with sodium sulfide dissolved in $\mathrm{NaOH}$ representing the main products. Performance data and capital cost estimates are summarized, respectively, in Tables 1 and 2 of Appendix AB-10-1. Ash removal for a single pass falls in the range 95-99\% for mine-cleaned coals containing up to $\sim 23 \%$ of ash; $\mathrm{SO}_{2}$ removals fall in the range $83-92 \%$. Total costs are estimated to amount to about $\$ 25$ per ton of coal cleaned, with additional savings possible when larger scale tests are performed.

\subsection{Fouling and Slagging}

Fouling and slagging probably represent the single most important class of operational problems that are encountered in coal utilization. While mitigation through coal cleaning, improved combustor designs, and new utilization techniques represent important practical procedures for dealing with fouling and slagging, it is apparent that improved understanding of the mechanisms and rates involved will not only provide needed insights but will also lead to more effective implementation of remedial measures.

An estimate of percentage losses in electricity-generation capability, produced by fouling and slagging for Western coals, is reproduced in Fig. 1.7-1. The costs to utilities from fouling and slagging have been estimated to range from $\$ 1 \times 10^{6} / \mathrm{yr}$ to as high as $\$ 8 \times 10^{6} / \mathrm{yr}$ in the operation of a $500-\mathrm{MW}_{\mathrm{e}}$ facility.

Slagging and fouling have been estimated in deposition measurements using ASTM procedures. Practical data are derived after employing deposit removals from heat-transfer surfaces during cleaning cycles. The ash characteristics are related to fuel types as the result of tests performed on laboratory, 


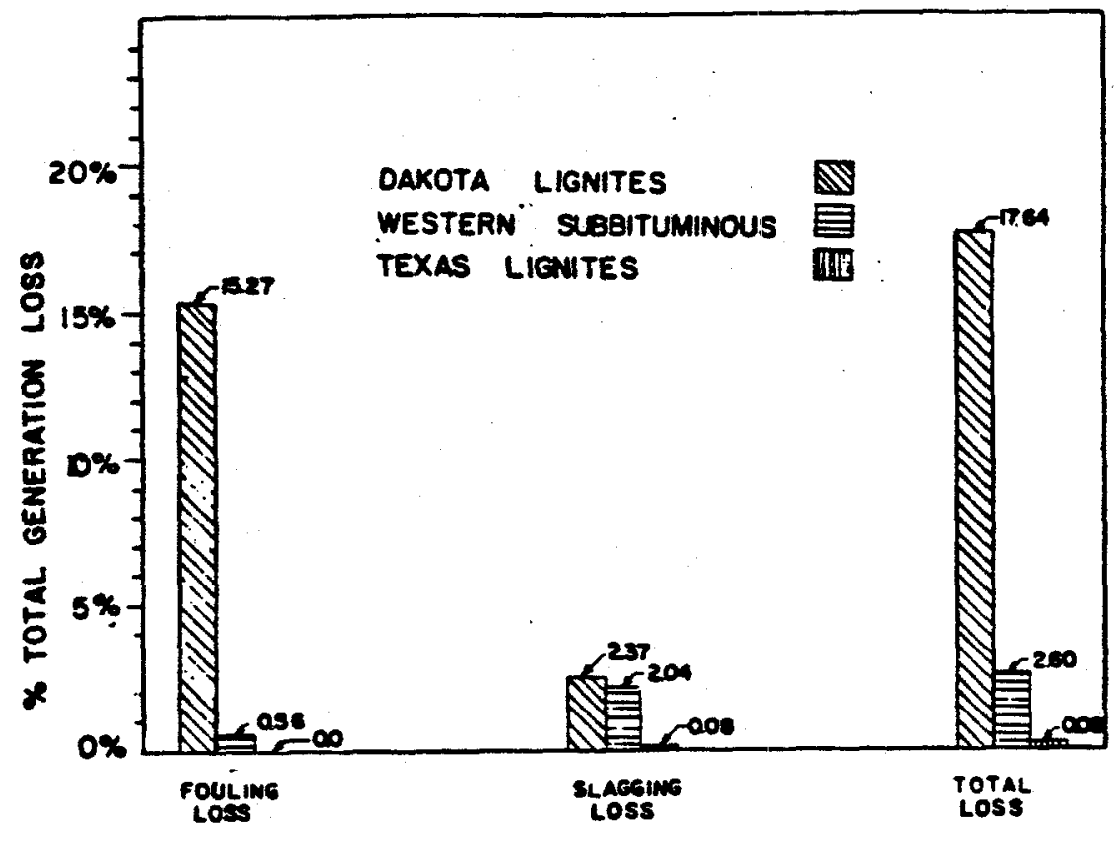

Fig. 1.7-1 Percentages of potential electricity-generation capacity lost for Western coals because of slagging and fouling; reproduced from a summary paper by $C$. L. Wagoner and G. Michaud 38 and based on data by F. R. Burkhardt at GFETC.

equipment, in pilot plants, and in larger units. The depositions affect boiler availability and capacity by influencing heat-release and heat-transfer rates, as well as unit efficiency. 38-40 Different overall heat-input rates apply for different coals (e.g., 1.59 to $2.06 \times 10^{6} \mathrm{Btu} / \mathrm{hr}$ for Midwest bituminous coals, $\sim 1.65 \times 10^{6} \mathrm{Btu} / \mathrm{hr}$ for Texas lignites, 1.8 to $2.5 \times 10^{6} \mathrm{Btu} / \mathrm{hr}$ for Eastern bituninous coals, etc.). 38 A slagging index has been used, which is defined in such a manner that it decreases linearly as the heat-input rate per unit of plan area increases. An overview of factors 
affecting ash deposition is reproduced in Fig. 1.7-2 and shows, in general, that coal type and all aspects of the utilization facility may be expected to influence slagging and fouling.

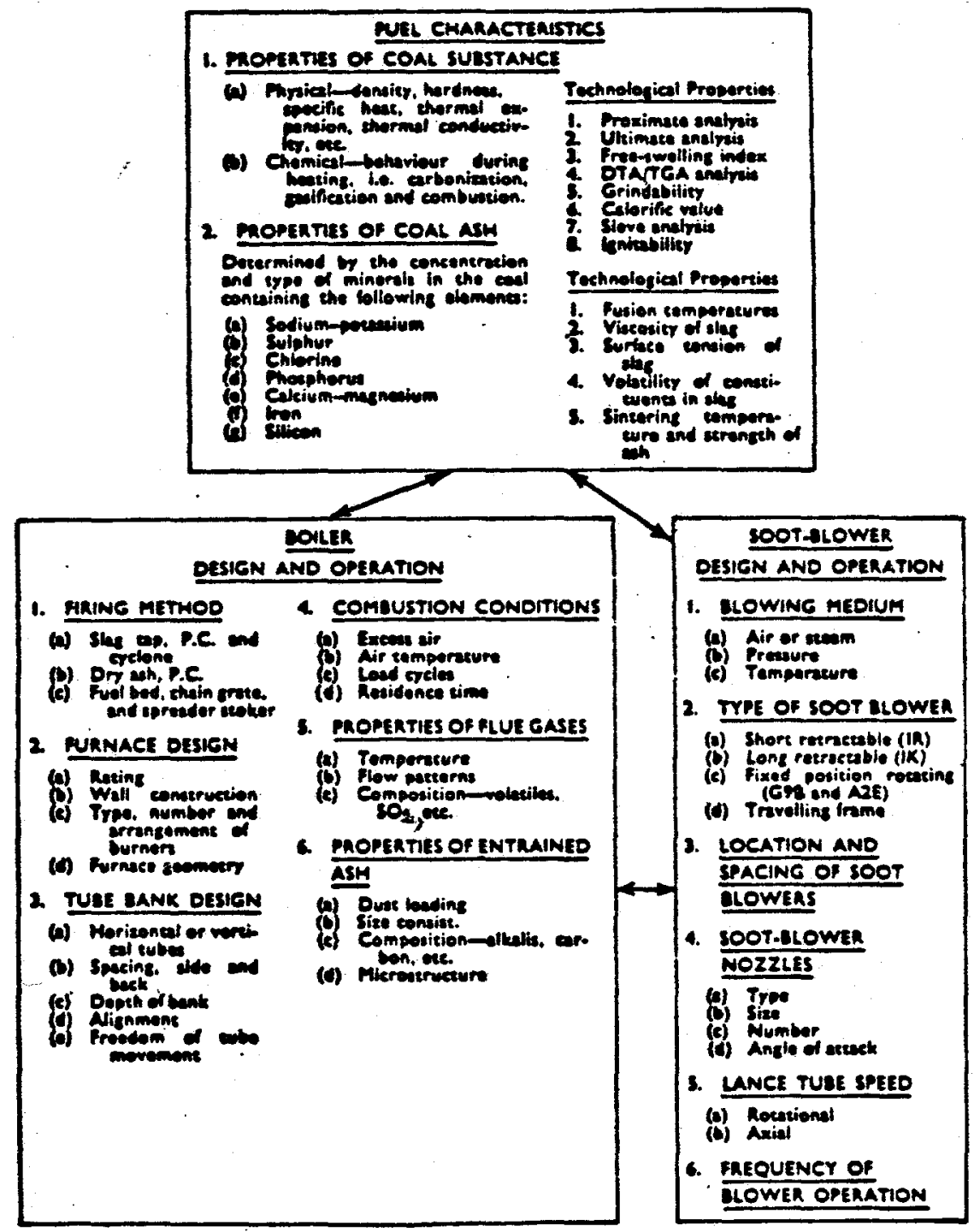

Fig. 1.7-2 Overview of some factors affecting slagging and fouling. Reproduced from Ref. 38 and based on a May 1963 review prepared for the Marchwood Conference on "The Mechanism of Corrosion by Fuel Impurities" by R. C. Attig and D. H. Barnhart. See also R. C. Attig and D. H. Barnhart, "A Laboratory Method for Evaluating Factors Affecting Tube Bank Fouling in Coal-Fired. Boilers," in The Mechanism of Corrosion by Fuel Impurities, pp. 173-182, Johnson and Litt1er, eds., Butterworths, London, 1963. 
Total losses (resulting from high and low superheat temperatures, clinker formation, convection fouling, needed supplemental oil firing, tube leaks, and capacity losses) were estimated to be $\$ 30,780,000$ over a six-month period for a total installed capacity of $9,500 \mathrm{MW}_{\mathrm{e}}$ or $\$ 3.24 \times 10^{6} /$ year-500 $\mathrm{MW}_{\mathrm{e}} \cdot{ }^{41}$ The coals used included Dakota and Texas lignites and Western subbituminous coals. Here, fouling refers to losses sustained directly or indirectly as the result of convection fouling; ash foulings of economizers, air preheaters and precipitators were not included and were not considered to be the result of fouling produced by the presence of sodium. Slagging losses include losses resulting from clinker formations and from high superheat temperatures. Seven plants were studied during the six-month period. Unit availability was determined and costs estimated based on the utility power costs. Two of the stations with the poorest availability had cyclone units, which are not well suited to highly fouling coals. These units had an average loss of availability of $17.64 \%$ when firing North Dakota lignites. If these units are ignored because cyclone units are not representative of current design practices, then the remaining stations had an average $2.60 \% 10 \mathrm{~s}$ of availability for Western subbituminous coals and $0.08 \%$ loss of availability for Texas lignites. The stations, units, availability, and costs are listed in the following table.

\begin{tabular}{|l|c|c|c|c|c|}
\hline Station & Units & $\begin{array}{c}\text { Design } \\
\text { MWe }\end{array}$ & $\%$ Loss & $\begin{array}{c}\text { Coal Price, } \\
\$ / 106 \text { Btu }\end{array}$ & $\begin{array}{c}\text { Estimated } \\
\text { cost, } \$ 10^{6}\end{array}$ \\
\hline \hline St. Clair & $1-4,6,7$ & 1325 & 2.50 & 1.38 & $\$ 23$ \\
Jim Bridger & $1-4$ & 2040 & 0.25 & 0.78 & N/A \\
Four Corners & $1-5$ & 2085 & 4.95 & 0.62 & $\$ 21$ \\
Big Brown & $1 \& 2$ & 1150 & 0.21 & 0.70 & $\$ 0.2$ \\
Monticello & $1-3$ & 1940 & 0.02 & 0.92 & -- \\
\hline Average & all & 1708 & 1.69 & 0.86 & $\$ 8.8$ \\
\hline
\end{tabular}


The listed data show that the average station of $1700 \mathrm{MW}_{\mathrm{e}}$ can expect a $1.7 \%$ loss in availability due to ash fouling and slagging at a cost of about $\$ 9 \times 10^{6} / \mathrm{yr}$ when burning relatively high sodium, high ash, low rank fuels. If we assume an average availability of $85 \%$, then substituting a better fuel would presumably improve the availability to $86.7 \%$. Using an average coal price of $\$ 0.83 / 10^{6} \mathrm{Btu}$ and assuming a $10^{4} \mathrm{Btu} / \mathrm{kw} \mathrm{e}^{-\mathrm{hr}}$ heat rate, we may estimate the allowable coal price for the good fuel and find it to be $\$ 0.88 / 10^{6}$ Btu. This result shows that operators of an average station can afford to pay a premium of $\$ 0.05 / 10^{6}$ Btu for good fuel and suggests that additive inspection, coal blending, use of higher grade coal, ion exchange, or coal washing would not be cost-effective methods for improving the performance of these units. Conscientious maintenance and more effective soot blowing will probably be more cost effective in reducing but not eliminating the slagging and fouling problems ${ }_{3}$

The preceding conclusions are different from those given in the original study and illustrate the difficulty of generalizing results about coal firing and attempting to draw correlations (such as relating availability loss to sodium in the ash) from limited data on a small sample of units. Nevertheless, there are costs associated with the use of low-rank fuels which could be reduced. If $R \& D$ is to be done in this area, then it should be directed toward the goal of improving predictive techniques that relate ash behavior, fuel properties, and furnace design. The calculated costs show that units designed to handle a difficult fuel will be more cost effective than retrofits to correct problems after the fact.

M. L. Jones (GFERC) has discussed direct, low-rank, pulverized coal combustion and emphasized the serious problems encountered with slagging and fouling. ${ }^{38}$ Depending on the coal 
used, highly alkaline ash adhering to walls (e.g., with North Dakota lignites or subbituminous coals) or ash with high $\mathrm{SiO}_{2}$ contents (e.g., with Gulf lignites) are produced. Low-rank coals contain substantial amounts of moisture ( 30 to $45 \%$ in lignites and 10 to $25 \%$ in subbituminous coals), are non-caking, have relatively low heating values $(\sim 6,500 \mathrm{Btu} / 1 \mathrm{~b})$ and sulfur contents ( $0.6 \%$ for subbituminous coals, $1.0 \%$ for 1ignites), produce highly variable alkaline ash, and have relatively high organic oxygen contents. The benefits of chemical additives (e.g., limestones or dolomites) and of physical control agents (e.g., vermiculite) in reducing ash fouling are under investigation; about 1 to $1.5 \%$ of the total fuel flow rate is typically added as limestone. Selected performance studies on a 220-MW $W_{e}$ wall-fired, utility boiler with low-rank coals showing $6-8 \%$ of $\mathrm{Na}$ in the ash allowed full-1oad operation for only about two weeks, whereas about one year of operation is anticipated with the use of limestone at full load. It is known that substantial boiler derating and the use of low peak temperatures $\left(₹ 1000^{\circ} \mathrm{C}\right)$ will reduce slagging. Experimental studies are in progress (e.g., at Foster Wheeler) to determine temperature levels below which fouling and slagging are substantially reduced. Critical issues relate to ash-deposition rates and deposit-tenacity correlations, which have been investigated for low-ash Montana subbituminous coal and high-Na lignite from Australia. A major data collection and consolidation effort has been initiated and will include data from laboratory, pilot and field studies. For low-rank coals, fundamental data are needed on (a) reactions of inorganic species in flames, (b) coal dust-air combustion in laminar and turbulent flames, (c) determinations of alkali metals in samples of particulates, chemical analyses of fouling deposits. Research recommendations on low-rank coals derived from a recent workshop have been classified as "highest priority" (see Table 1.7-1) and "lower priority" (see Table 1.7-2). 
Table 1.7-1 GFERC research recommendations on low-rank coals (LRC) of "highest priority."

\section{A. Basic Research}

\begin{tabular}{|c|c|}
\hline From LRC Studies & $\begin{array}{c}\text { From Workshop on Basic Coal } \\
\text { Science }\end{array}$ \\
\hline $\begin{array}{l}\text { Classification of standard } \\
\text { low-rank coal samples; reactions } \\
\text { between alkali materials and } \\
\text { sulfur; compositions and char- } \\
\text { acteristics of ashes and slags. } \\
\text { from low-rank coals and peats. }\end{array}$ & $\begin{array}{l}\text { Methods for the determina- } \\
\text { tion of macerals (petro- } \\
\text { graphic characterization); } \\
\text { standard low-rank coal sam- } \\
\text { ples; organic structure of } \\
\text { low rank coals; distribu- } \\
\text { tion of inorganics; devola- } \\
\text { tilization reactions; mois- } \\
\text { ture determinations. }\end{array}$ \\
\hline
\end{tabular}

\section{B. Combustion Research}

Ash fouling and slagging mechanisms; control of fouling and slagging with additives; direct ignition of pulverized coal without oil; determination of the thermal properties (emissivities and absorptivities) of ash at high temperatures; determination of the form and distribution of inorganic constituents; sulfur retention on ash as a function of ash composition and operating parameters, including combustion modifications for low NOx; on-line measurements of fouling and slagging (full-scale and pilot units) and correlation with fuel characteristics and operating parameters; mechanisms of ash fouling; evaluation and use of additives to reduce fouling and slagging; corrosion rates for low-rank coals as a function of ash composition, metal temperature, and metal type. 
Table 1.7-2 GFERC research recommendations on LRC of "lower priority."

A. Basic Research

\begin{tabular}{|l|l|}
\hline \multicolumn{1}{|c|}{ From LRC Studies } & $\begin{array}{l}\text { From Workshop on Basic Coal } \\
\text { Sciences }\end{array}$ \\
\hline $\begin{array}{l}\text { Surface characteristics of low- } \\
\text { rank coals and peat fines;kine- } \\
\text { tics and reaction mechanicsms } \\
\text { of LRC and their chars with } \mathrm{H}_{2} \mathrm{O}, \\
\mathrm{H}_{2}, \mathrm{CO}, \text { and } \mathrm{CO}_{2} .\end{array}$ & $\begin{array}{l}\text { Within-seam variability of } \\
\text { characteristics and properties; } \\
\text { high-temperature oxidation. }\end{array}$ \\
\hline
\end{tabular}

\section{B. Combustion Research}

Improved boiler cleaning procedures; temperature limitations vs. boiler corrosion; improved stoker furnace for small-scale applications; devolatilization and carbon burnout characteristics and the effect of burner/furnace modifications for NOx control; probe testing of burners on full-scale, boilers to provide input data for furnaces; assessment of fouling and slagging leading to improved guidelines for preparing boiler specifications; a $1-5$ TPH, PC-fired test facility to study fouling and slagging at larger scale than in the present pilot units; effects on boiler tubes of using water blowers to clean low-rank coal boilers and determine factors controlling blower effectiveness; fluidizedbed combustion; low-rank coal/water slurry combustion and lowrank coal/oil slurry combustion; improvements in cyclone firing of LRC; effective $\mathrm{SO}_{x} / \mathrm{NO}_{x}$ and particulate controls for smaller industrial stokers operating on LRC; development of more reliable flame scanners, more reliable instruments to measure furnace flue gas temperatures, and cheaper and more reliable, continuous $\mathrm{SO}_{2}$ analyzers. 
R. Bryers (Foster Wheeler Development Corp.) has prepared a comprehensive overview of information derived on fouling and slagging from pilot and full-scale units and correlations with predictive indices in conventionally-fired steam generators. This presentation is reproduced in full in Appendix AB-3. Particularly noteworthy are interesting observed differences between elementary compositions of coals and corresponding slag samples. While a wealth of empirical information has been collected and control measures are necessarily implemented when slagging and fouling require remedial measures in operating boilers, fundamental understanding is limited with regard to each of the following basic problems: (a) the relation between measures taken for coal beneficiation and slagging and fouling, (b) the extent to which deleterious depositions can be controlled by aerodynamic measures, (c) the quantitative relations between coal mineral contents and the physicochemical processes that lead to slagging and fouling, (d) the roles of ash loadings and particle-size distributions in deposit formations, (e) the mechanisms involved in selective depositions of minerals, (f) predictions and verifications of deposit compositions and their spacial variations, (h) the phase behavior and phase changes of deposits with temperature variations, (i) the strengths and durabilities of deposits and their stabilities to soot blowing and removal attempts.

A second generation laboratory ashing furnace has been described by C. L. Wagoner, 39 which represents an improved design of an earlier, small-scale pulverized coal burner that was used to produce fly ash with properties similar to those of ash produced in a utility generator. The new design 39 is suitable for combustion studies on COM to elucidate the formation and characteristics of the deposits formed on sootblowing heat-transfer surfaces. A schematic diagram of the system design is shown in Fig. 1.7-3 and the test section, where depositions are measured, is sketched in Fig. 1.7-4. Experimental studies using this equipment have shown that removal of 


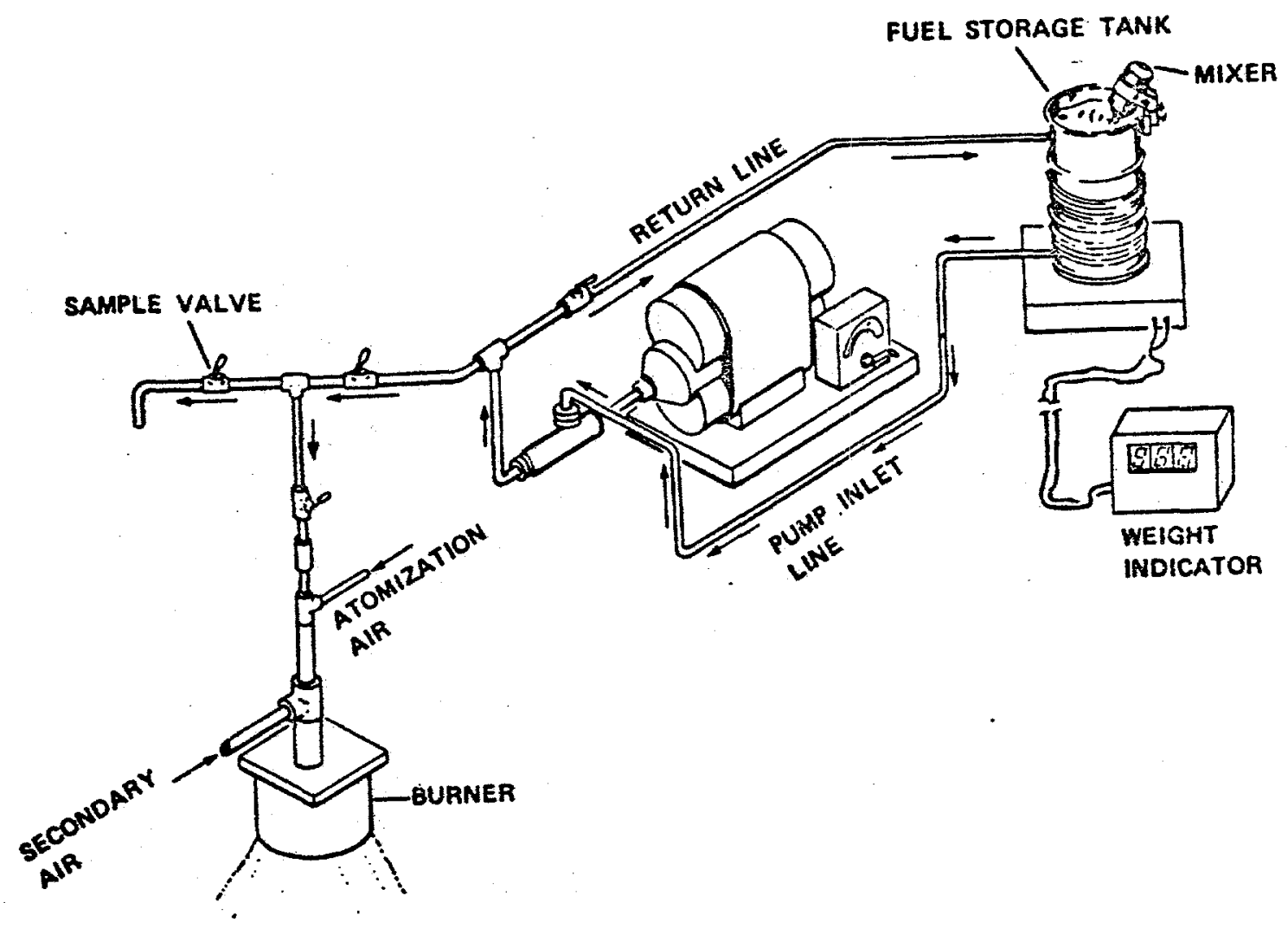

Fig. 1.7-3 Schematic diagram of a system for combustion studies of solid-1iquid mixtures; reproduced from C. L. Wagoner. 39

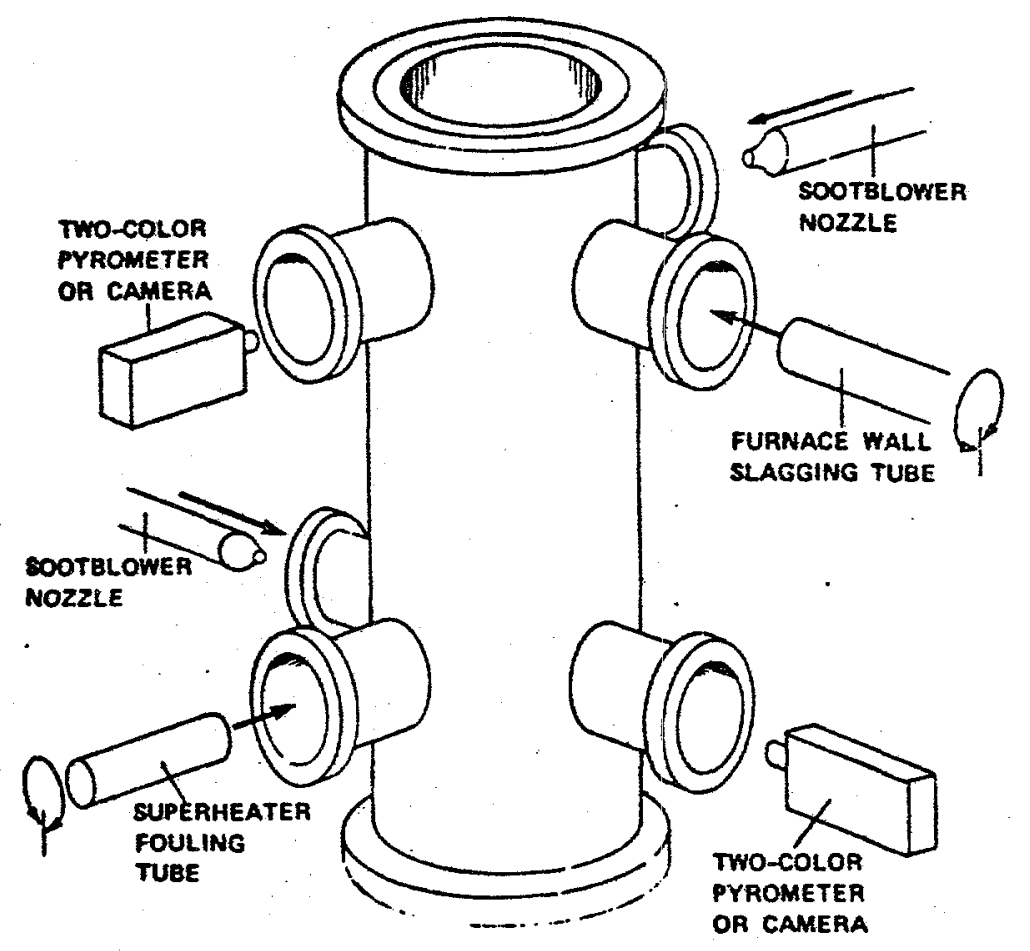

Fig. 1.7-4 Conceptual drawing of the test section used for sootdeposition studies; reproduced from C. L. Wagoner. 39 
about one half of the ion-exchangeable calcium from a subbituminous coal had a profound effect on fouling and slagging 40 and led to reduced heat-transfer rates and sootblower cleaning capabilities. ${ }^{40}$ The observed effects were appreciably larger than could be accounted for on the basis of phase-equilibrium diagrams. 40

The costs and penalties associated with the production of fireside deposits are being evaluated. They are often sitespecific and not well quantified. An adequate and well integrated fundamental research program remains to be developed. Fundamental studies on ash deposits and corrosion should be performed, even though the demonstrable connection between these studies and control in large boilers remains to be made. The members of CCAWG judge the currently funded efforts on fundamental studies in these fields to be inadequate in view of the economic importance of reliable performance of (large) boilers to utilities and industrial users all over the world.

\subsection{Coal-Plant Safety; Flammability of Coa1-Dust-Air Mixtures}

Coal-dust fires and explosions occur in mines and in coal preparation for use in all types of boilers. The tendency of coal piles to heat spontaneously has been well recognized for a long time.

During the period 1967-1979, somewhat more than three fires or explosions per year were reported in coal pulverizers or coal-fired boilers. ${ }^{4}$ of the total number of 40 accidents, 8 involved pulverizers while 32 occurred in furnaces. These occurrences may be responsible for significant down time and accounted for as much as $74 \%$ of lost generatig capacity at one utility plant. ${ }^{4}$ About $15 \%$ of capacity loss produced by pulverizer failures is attributable to fires and explosions. ${ }^{44}$ Furnace incidents usually result from operator errors. In some cases, it may be desirable to improve internal designs of operating units. Pulverizer and storage-unit incidents may require improved handling of coals prior to utilization. 
Although the frequency of fires and explosions has declined since the mid-sixties, problems remain and the frequencies of incidents may be expected to grow as the total coal-utilization rate increases.

\subsection{A Oxidation and Heating of Coals ${ }^{45, *}$}

Oxidation on exposure to air of coal piles is responsible for heating if heat generation by slow combustion exceeds heat losses. The following variables determine the rate of heat release: the nature (e.g., ash and moisture contents, pore size, composition, etc.) and past history of the coal, its temperature, and the atmospheric constitution in the immediate vicinity of the coal pile. For determinations of relative tendencies for self heating, an adiabatic calorimeter was used. 45 The coal was crushed in stages ( $d<1 / 4-$ inch), dried at $212^{\circ} \mathrm{F}$ in nitrogen, and then introduced into the calorimeter after inspections to determine size distributions of sequentially piled coal layers. Initial temperatures of $80-120^{\circ} \mathrm{F}$ were used for subbituminous coals and lignites; high volatile bituminous coal of rank $A$ or higher was heated to $140-200^{\circ} \mathrm{F}$. Oxidation tests were performed on 31 coals, with flowing gases containing at least $85 \% \mathrm{O}_{2}$ in the effluents; for a $36^{\circ} \mathrm{F}$ temperature rise of the coal, the oxygen flow rate had to be increased by $50 \%$. The final calorimeter data were well correlated by the expression

$$
\mathrm{R}_{1} / \mathrm{R}_{2}=\exp \mathrm{n}\left[\left(1 / \mathrm{T}_{1}\right)-\left(1 / \mathrm{T}_{2}\right)\right]
$$

where $R_{i}=$ heating rate in ${ }^{\circ} F / h r$ at $T_{i}(i=1$ or 2$)$ and $n$ varied from -2920 to -4800 depending on coal type. In addition to the calorimeter, steam-jacketed oxidation equipment was used to determine characteristic oxidation rates at $212^{\circ} \mathrm{F}$ for 46 coals. A11 of the coals were identified in terms of proximate and ultimate analyses, heating value, forms and percentages of sulfur, and rank.

The percentage of oxygen consumed $(x)$ per unit mass in

* Some early detailed information is given here in order to emphasize the fact that all aspects of coal science and applications have been the subject of quantitative analyses. 
the oxidation tests varied with time $(t)$ according to the relation

$$
\mathrm{X}=\mathrm{C} t^{\mathrm{b}} \text {, }
$$

where both $C$ and $b(0.34 \leqslant b \leqslant 0.806)$ depend on coal type with $b$ generally increasing with coal rank. The rate of reaction in: of $\mathrm{O}_{2}$ consumed per day per unit weight of dry, mineral-matterfree coal is

$$
R=b c^{1 / b} x^{(b-1) / b} \text {. }
$$

The value of $R$ for $X=1$ is defined to be a characteristic oxidation rate. It is apparent from Eq. (1.8-2) that the rate of oxidation increases rapidy with time for the specified values of $b$. Preoxidation followed by cooling reduced self-heating tendencies.

The heating rate $R_{i}$ at $212^{\circ} \mathrm{F}$ was found to vary linearly with the 0.68 power of the oxygen concentration $\left(1 \leqslant\left(\mathrm{O}_{2}\right)\right.$ in $\leqslant 20.5)$, viz.

$$
\mathrm{R}_{1} / \mathrm{R}_{2}=\left[\left(\mathrm{O}_{2}\right)_{1} /\left(\mathrm{O}_{2}\right)_{2}\right]^{0.68} .
$$

Using data of Needham and Hall on the relation between surface area and statistical mean shape, ${ }^{46}$ the surface area in $\mathrm{ft}^{2}$ per $1 \mathrm{~b}(\bar{S})$ as a function of arithmetic mean sieve opening (M) in inches was found to be

$$
\overline{\mathrm{S}}=1.033 / \mathrm{M}^{1.1} \text {. }
$$

In the derivation of Eq. (1.8-5), the following assumptions were made: constant coal density, the statistical diameter equals 1.4 times the arithmetic mean sieve opening $M$, the volume constant $k$ of Ref. 46 is given by $k=0.29 \mathrm{M}^{0.15}$, coal particle length-to-breath ratio $=1.5$. Based on a few quantitative data, it has been estimated ${ }^{47}$ that the rate of oxidation (or the rate of heating) of coal varies as $(\bar{S})^{1 / 3}$. The average value of $\bar{s}$ used in Ref. 45 was $40 \mathrm{ft}^{2} / 1 \mathrm{~b}$.

The cited early investigations have been supplemental by numerous empirical studies dealing with spontaneous combustion 
of coals 48,49 and with self-heating ${ }^{50}$ and storage technology for coals. 51

\subsection{B Flammability of Coal-Dust-Air Mixtures}

Fundamental combustion data (including estimations of lean flammability limits, flame temperatures, ignition energies, and particle-size effects) have been systematically accumulated by M. Hertzberg and his associates at the U.S. Bureau of Mines. 52 Measurements were performed in an 8-1iter vesse1.

The measured lean limit for near-horizontal flame propagation was found to be nearly independent of particle size for small particles and corresponds to $\sim 135 \mathrm{mg} / \mathrm{\alpha} .52$ Required ignition energies are hundreds of joules. 52 The energy needed for ignition has been mapped as a function of the lean-limit concentration for various hydrocarbons and also for coal-dust dispersions in air. Maps are available showing flammable and thermally ignitable, flammable but not thermally ignitable, and nonflammable regions as functions of temperature and particle concentrations for selected coals. 52 In general, the probability of explosion is the product of the probability of finding a flammable volume and the probability of encountering an ignition source of adequate strength. Flammable mixtures are usually encountered in coal pulverizers. Hence, explosion avoidance means avoidance of ignition. Nonflammable coal-dust dispersions may be created by reducing oxygen concentrations below $11 \%$ or by the introduction of sufficiently large concentrations of steam, flue gases or other "inerting" materials (e.g., concentrations of $\mathrm{NH}_{4} \cdot \mathrm{H}_{2} \mathrm{PO}_{4}$ exceeding about 20-30\% of the coal-dust concentrations). The amounts of $\mathrm{KHCO}_{3}$, rock dust or $\mathrm{NaCl}$ required to render the coals inert in small-scale tests were found to be in good agreement with similar results obtained in large-scale mine experiments. 52

The rich flammability limits are much less well defined, pose a safety issue, and require clarification through further study. 
Operational difficulties can be resolved or reduced by intelligent applications of available data and knowledge. Nevertheless, coal-dust explosions do occur and represent a hazard, not only in coal-mining operations but also in the type of coal handling involved in the use of pulverized coal in utility and other boilers. For this reason, improved quantitative understanding of fundamental processes may well deserve augmented effort, especially with regard to the possible importance of equipment specifications in defining both flammability limits and ignition requirements. This point of view was supported by participants at a 1982 workshop. 53

It is important to remain cognizant of these studies since the results may have important bearings on future accident assessments as coal use increases.

\subsection{Environmental Concerns, Regulations and Studies}

Environmental concerns have led to regulations of effluent concentrations from combustion sources. These, in turn, have been difficult or costly to meet and have served as primary incentives for studies and system-design modifications. Current federal standards for boilers producing steam to generate more than $73 \mathrm{MW}_{\mathrm{e}}$ are $0.61 \mathrm{~b}$ of $\mathrm{NO}_{\mathrm{x}}$ per $10^{6} \mathrm{Btu}$ for bituminous coals and $0.5 \mathrm{lb}$ of $\mathrm{NO}_{\mathrm{x}} / 10^{6} \mathrm{Btu}$ for subbituminous coals. It is likely that more rigid control measures will be imposed in the future. Current limits are $1.21 \mathrm{bs} / 10^{6}$ Btu for $S O_{x}$, with the supplementary requirement of $90 \%$ removal whenever uncontrolled $\mathrm{SO}_{\mathrm{x}}$ emissions exceed $0.61 \mathrm{~b} / 10^{6} \mathrm{Btu}$; otherwise, $70 \% \mathrm{re-}$ moval is required. Particulates are limited to $0.02 \mathrm{lb} / 10^{6} \mathrm{Btu}$ and are not presently qualified with regard to chemical composition, although a number of investigators have expressed apprehension about the possible presence of carcinogenic hydrocarbons and other carcinogenic compounds on particulate emissions and flyash.

A great deal needs to be learned about the control of NO $x$ emissions through combustion modifications that emphasize desirable competitions between $\mathrm{NO}_{\mathrm{x}}$ formation and depletion 
processes. Studies are in progress on $\mathrm{NO}_{x}$ control using staging and combustion modifications. Removal of $\mathrm{NO}_{\mathrm{x}}$ by reduction with $\mathrm{NH}_{3}$ is a well developed procedure for some gas mixtures, provided the $\mathrm{SO}_{x}$ concentrations are not excessively high. The oxides of sulfur are removed by wet scrubbing and by limestone scavenging; their initial concentration levels are reduced by the use of low-sulfur coals, by coal cleaning, etc. The formations of particulates and flyash may be minimized by coal beneficiation and they may be removed from the flue gases by using electrostatic precipitation and other means.

The following is a suggested listing of selected research areas: ${ }^{54}$ (a) design configurations and cost assessments to meet possible further reductions in allowable $\mathrm{NO}_{x}$ emissions; (b) integrated management of boiler feed, boiler operations, and boiler emissions; (c) coal beneficiation as a technique for reducing pollutant outputs; (d) $\mathrm{SO}_{\mathrm{x}}$ removal within the boilers and from the flue gases; (e) improved understanding of chemical processes that couple $\mathrm{NO}_{x}, \mathrm{SO}_{x}, \mathrm{HC}$, and flyash productions; (f) chemical nature and possible toxicological implications of hydrocarbon and trace-metal emissions; ( $g$ ) modifications of fluidized bed combustors to reduce $\mathrm{NO}_{x}$ emissions and carbon carryover; the special difficulties that arise in the control of emissions from very small combustors.

There is a substantial DOE (METC) program dealing with advanced environmental control technologies. Past and current studies include developments of flue-gas cleanup (using lime and limestone scrubbers, other flue gas desulfurization techniques, and combined $\mathrm{NO}_{\mathrm{x}} / \mathrm{SO}_{\mathrm{x}} /$ particulate flue-gas cleanup), gasstream cleanup (for turbine systems, fuel cells and other technologies), and studies of cleanup base technologies (including waste management, instrumentation, and systems economic comparisons). DOE/METC has phased out RGD on the use of lime and limestone relating to advanced flue-gas desulfurization (FGD). Studies continue on the following topics: (a) removal of $\mathrm{NO}_{\mathrm{x}} / \mathrm{SO}_{\mathrm{x}}$ /particulates and flue-gas cleanup using such novel ideas as E-beams to facilitate reactions for conversions of 
$\mathrm{NO}_{\mathrm{x}}$ and $\mathrm{SO}_{\mathrm{x}}$; (b) gas-stream cleanup at elevated temperatures $\left(>10^{30} \mathrm{~F}\right)$ and pressures $(>6.5 \mathrm{~atm})$ in $\mathrm{PFBCs}$ and turbines, with emphasis of the effects of $\mathrm{Na}$ on turbine life and the utilization of absorbents such as activated bauxite, diatomaceous earths, and other aluminosilicates; (c) particulate removal by using a variety of existing and developing experimental techniques (compare Section 1.9B).

\subsection{A The EPRI Program}

An important environmental assessment program has been supported by EPRI for some time. Major current EPRI research areas and proposed funding for the period 1983-87 are summarized in Table 1.9-1. These programs clearly reflect electric utility needs and priorities. Pilot-plant test data on integration of a pilot cooling tower with stack-gas clean-up components are expected to be available by 1985; a final report on integrated environmental controls (IEC), including their effects on heat rate, is to be available by 1987 . Full-scale applications of IEC will commence about 1984. An assessment is currently in progress on Japanese power-plant design and operating practices, including enforcement of rigorous environmental control measures.

\subsection{B Particulate Clean-Up}

Advanced concepts to implement particulate clean-up are being supported by DOE, EPRI, EPA, and industrial concerns. A summary of techniques, developers, process descriptions, and 1982 program status is listed in Table 1.9-2 for studies supported by DOE/METC.

\subsection{Nove1 Developing Control Technologies}

A substantial program of promising, novel control strategies is being supported by the principal governmental agencies and by EPRI. An interesting example of this type of work is 
Table 1.9-1 EPRI environmental assessment program (as of September 1982) with proposed budgets (in millions of dollars) for 1983-1987; the abbreviations 1isted in the first column refer to EPRI study sections and have the following meanings: $\quad E P C=$ Environmental Physics and Chemistry, $E S=$ Ecological Studies, HS = Health Effects.

\begin{tabular}{|c|c|c|c|c|c|}
\hline $\begin{array}{l}\text { Air quality } \\
\$ 57.5\end{array}$ & $\begin{array}{l}\text { Local air } \\
\text { quality }\end{array}$ & $\begin{array}{l}\text { Regional } \\
\text { air quality }\end{array}$ & $\begin{array}{l}\text { Indoor air } \\
\text { quality }\end{array}$ & $\begin{array}{l}\mathrm{CO}_{2} \\
\text { effects }\end{array}$ & \\
\hline $\begin{array}{l}\text { Atmospheric deposition } \\
\$ 29.2\end{array}$ & $\begin{array}{l}\text { Lake acidifi- } \\
\text { cation }\end{array}$ & Crops & Forests & $\begin{array}{l}\text { Aquatic } \\
\text { biota }\end{array}$ & $\begin{array}{l}\text { Miti- } \\
\text { gation }\end{array}$ \\
\hline $\begin{array}{l}\text { Community hea1th } \\
\$ 24.7\end{array}$ & $\begin{array}{l}\mathrm{SO}_{\mathrm{X}}-\mathrm{NO}_{\mathrm{X}}-\text { mixed } \\
\text { po11utants }\end{array}$ & $\begin{array}{l}\text { Fine } \\
\text { particles }\end{array}$ & $\begin{array}{l}\text { Community } \\
\text { epidemiology }\end{array}$ & Organics & \\
\hline $\begin{array}{l}\text { Land \& water quality } \\
\$ 18.1\end{array}$ & Solid waste & $\begin{array}{l}\text { Priority } \\
\text { pollutants } \\
\text { in water }\end{array}$ & & & \\
\hline $\begin{array}{l}\text { Toxic substances } \\
\$ 13.1\end{array}$ & $\begin{array}{l}\text { Pollutant } \\
\text { testing }\end{array}$ & $\begin{array}{l}\text { Waste } \\
\text { toxicology }\end{array}$ & $\begin{array}{l}\text { Biocide } \\
\text { use }\end{array}$ & $\begin{array}{l}\text { Microcosm } \\
\text { develop- } \\
\text { ment }\end{array}$ & \\
\hline $\begin{array}{l}\text { Experimental methods } \\
\$ 3.7\end{array}$ & $\begin{array}{l}\text { Remote } \\
\text { measurements }\end{array}$ & $\begin{array}{l}\text { Analysis \& } \\
\text { measurement } \\
\text { techniques }\end{array}$ & & & \\
\hline $\begin{array}{l}\text { Aquatic \& terrestrial } \\
\text { resources } \\
\$ 4.2\end{array}$ & $\begin{array}{l}\text { Compensation } \\
\text { mechanisms }\end{array}$ & $\begin{array}{l}\text { Ecological } \\
\text { monitoring }\end{array}$ & $\begin{array}{l}\text { Cooling } \\
\text { system } \\
\text { biota }\end{array}$ & $\begin{array}{l}\text { Bird-facil } \\
\text { ity inter- } \\
\text { actions }\end{array}$ & \\
\hline
\end{tabular}


Table 1.9-2 Summary of DOE/METC particulate control techniques under development during 1982.55

\begin{tabular}{|c|c|c|c|}
\hline $\begin{array}{c}\text { Control } \\
\text { Technology }\end{array}$ & Developer & Description & Status \\
\hline $\begin{array}{l}\text { Dry-p1ate } \\
\text { scrubber }\end{array}$ & $\begin{array}{l}\text { Air Pollution } \\
\text { Technology }\end{array}$ & $\begin{array}{l}\text { An electrostatic barrier is used } \\
\text { with a multiple-bed, granular } \\
\text { filter in a serial configuration. }\end{array}$ & $\begin{array}{l}\text { Cold-flow tests are being } \\
\text { completed; AFBC tests and } \\
\text { simulated PFBC tests are } \\
\text { in progress; efficiency: } \\
99 \frac{0}{0}+\end{array}$ \\
\hline $\begin{array}{l}\text { E1ectrosta- } \\
\text { tically- } \\
\text { enhanced } \\
\text { filter bed }\end{array}$ & $\mathrm{GE} / \mathrm{EFB}$ & $\begin{array}{l}\text { An electrostatic barrier is used } \\
\text { on a moving panel-bed granular } \\
\text { filter with image-change enhance- } \\
\text { ment. }\end{array}$ & $\begin{array}{l}\text { Cold-flow tests have been } \\
\text { completed in AFBC and } \\
\text { showed severe media attri- } \\
\text { tion; further tests are } \\
\text { in progress. }\end{array}$ \\
\hline $\begin{array}{l}\text { Magnetical- } \\
\text { ly-stabili- } \\
\text { zed bed }\end{array}$ & Exxon & $\begin{array}{l}\text { The barrier is a moving panel-bed } \\
\text { granular filter using an exter- } \\
\text { nally applied magnetic field to } \\
\text { control and order ferromagnetic } \\
\text { media. }\end{array}$ & $\begin{array}{l}\text { A bench-scale PFBC test } \\
\text { is underway. }\end{array}$ \\
\hline $\begin{array}{l}\text { Cross-flow } \\
\text { ceramic } \\
\text { filter }\end{array}$ & Westinghouse & $\begin{array}{l}\text { The barrier is a cross-flow mem- } \\
\text { brane filter using monolithic } \\
\text { porous ceramic media. }\end{array}$ & $\begin{array}{l}\text { A bench-scale test at ele- } \\
\text { vated temperatures and } \\
\text { pressures showed } 99.9 \%+ \\
\text { efficiency but problems } \\
\text { associated with thermal } \\
\text { expansion were observed. }\end{array}$ \\
\hline $\begin{array}{l}\text { Acoustic } \\
\text { agglomera- } \\
\text { tion }\end{array}$ & Suny-Buffalo & $\begin{array}{l}\text { Augmentation agglomeration is ap- } \\
\text { plied; sonic energy agglomerates } \\
\text { small particles into larger par- } \\
\text { ticles to facilitate removal. }\end{array}$ & $\begin{array}{l}\text { The effect occurs at sound } \\
\text { levels greater than } 960 \mathrm{~dB} \\
\text { and frequencies of } 9000- \\
1500 \mathrm{~Hz} \text {. }\end{array}$ \\
\hline
\end{tabular}


ovided by the E-beam scrubber.*

i. The E-Beam Scrubber 56

The E-beam scrubber was developed by Ebara in Japan (since 1969-70) and is currently being pursued jointly by Avco and Ebara, who have cross-1icensing agreements, with Ebara holding most of the patents and Avco contributing expertise in the areas of electron-beam technology developed in connection with excimer and other laser programs. According to its proponents, the Ebeam scrubber will allow cost-effective $\mathrm{SO}_{x}$ and $\mathrm{NO}_{x}$ removals, not only at currently mandated effluent levels but also if substantially more rigorous clean-up standards are implemented in the future. While a great deal of useful empirical information has been obtained in Japan, the fundamental processes involved in effluent gas clean-up on exposure to electron beams are not adequately understood and, therefore, theoretical design-optimization techniques are not yet available. DOE funding of $\$ 600,000$ is to be used for studies on a PDU (gas flow rate of $20,000 . \mathrm{ft}^{3}$, min). In Japan, effluent control technologies are so widely implemented that there remains only a very limited market potential without the legislation of new performance standards. This is said to be one of the reasons for Ebara's involvement in a joint venture with Avco.

A schematic diagram of the removal system is shown in Fig. 1.9-1. The novel feature is the use of $10 \mathrm{w}$-temperature chemical reactions with $\mathrm{NH}_{3}$ during bombardment by electrons. For the conditions shown in Fig. 1.9-1, the $\mathrm{SO}_{\mathrm{x}}$ and $\mathrm{NO}_{\mathrm{x}}$ are converted to the fertilizers $\left(\mathrm{NH}_{4}\right)_{2} \mathrm{SO}_{4}$ and $\mathrm{NH}_{4} \mathrm{NO}_{3}$, respectively, albeit at the expense of $\mathrm{NH}_{3}$ and energy; without $\mathrm{NH}_{3}$ injection, sulfuric and nitric acids are formed, which may also be readily collected. As is shown in Table 1.9-3, the final $\mathrm{SO}_{x}$ and $\mathrm{NO}_{x}$ concentrations are substantially lower than the currently mandated levels.

*Information on this system was supplied by $V$. Shui of the AVCO/ Everett Research Laboratory. 
Fig. 1.9-1 The AVCO/Ebara combined $\mathrm{SO}_{\mathrm{X}}, \mathrm{NO}_{\mathrm{X}}$ and particulate-removal system.

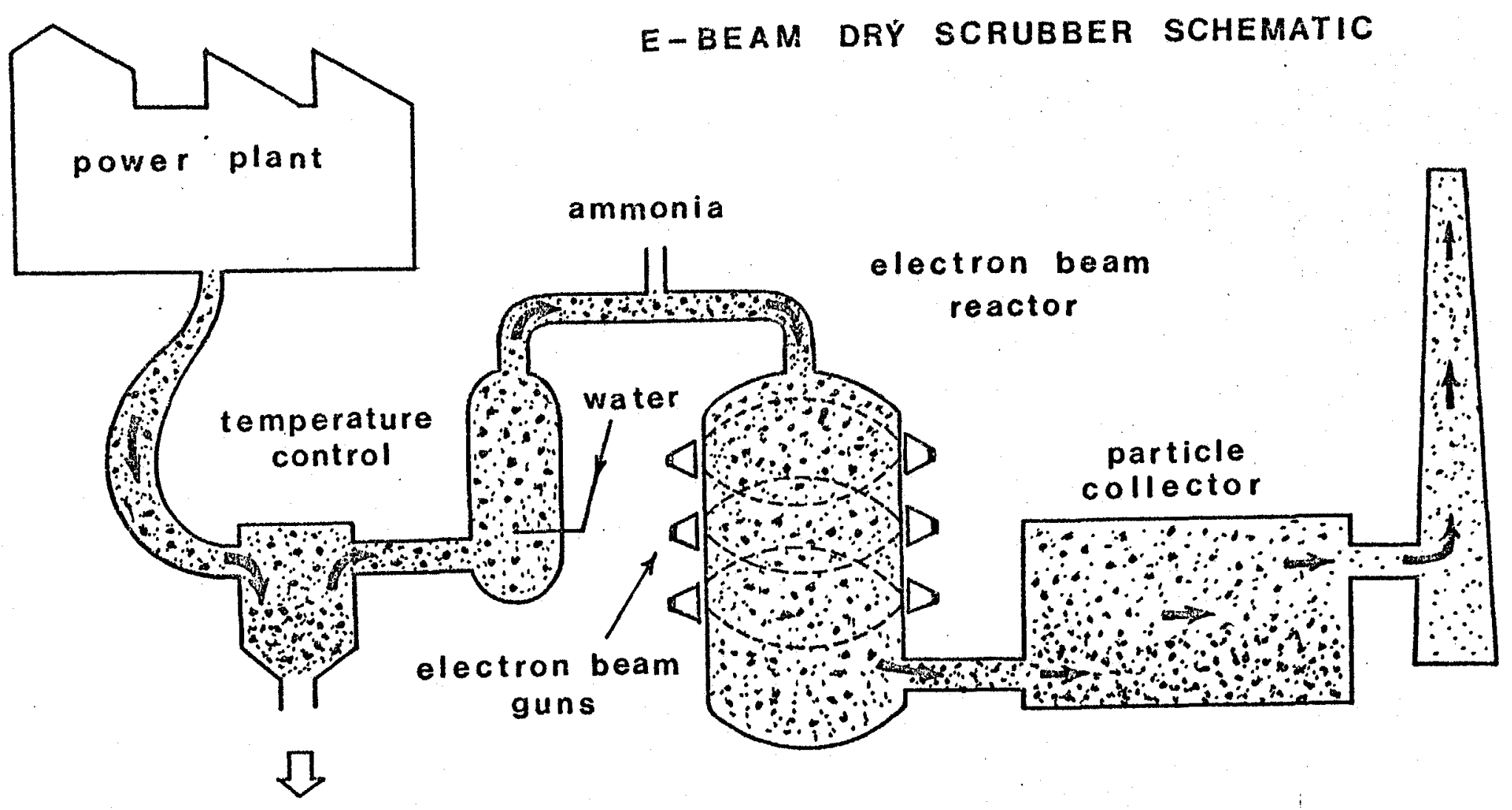

fly ash

$$
\mathrm{SO}_{x}, \mathrm{NO}_{x}, \mathrm{NH}_{3}, \mathrm{O}_{2} \longrightarrow \underset{\text { sulphate }}{\text { ammonium }}+\underset{\text { nitrate }}{\text { ammonium }} \longrightarrow \text { fertilizer }
$$


Table 1.9-3 Performance estimates for percentage removals of 55 $\mathrm{SO}_{\mathrm{X}}$ and $\mathrm{NO}_{\mathrm{x}}$ using the AVCO/Ebara E-beam scrubber.

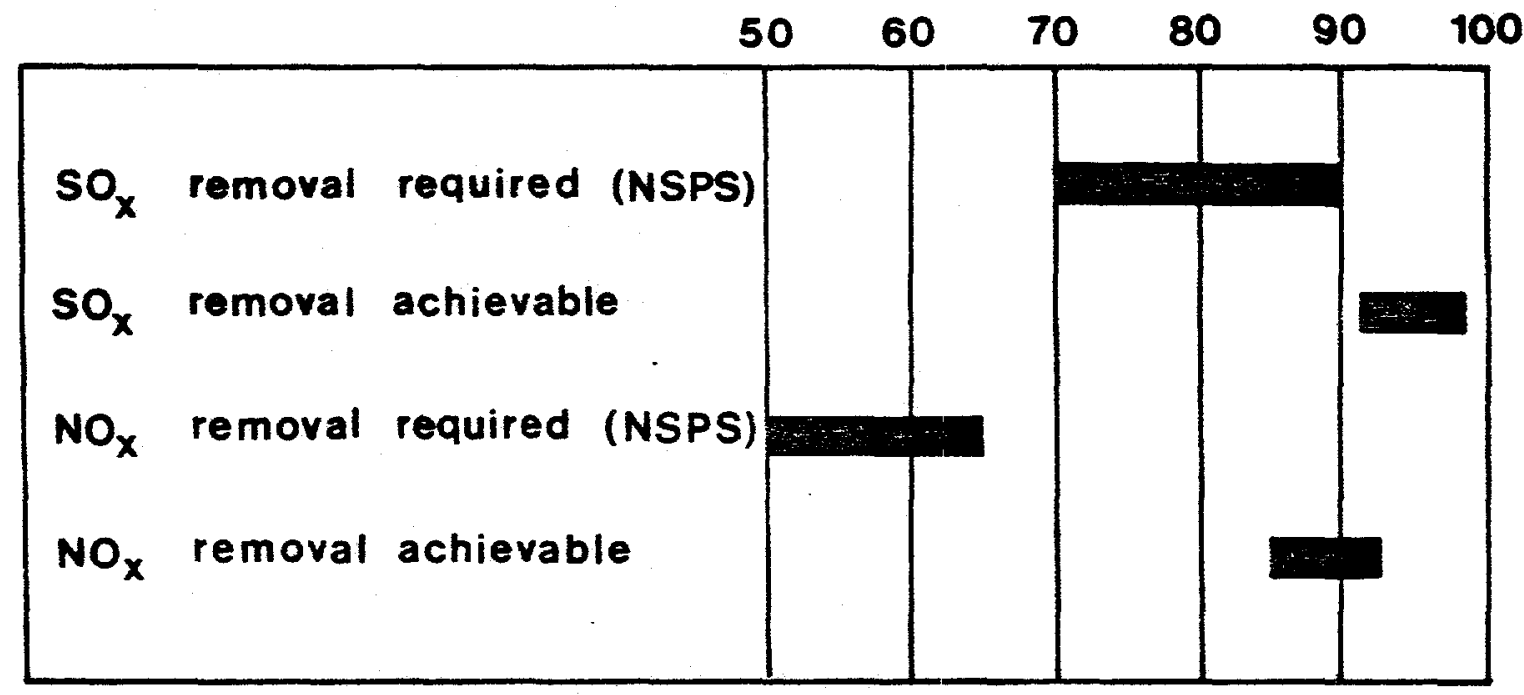


A 1980 costing study of the E-beam process was performed by Gibbs and Hill. The results of this study are summarized in Table 1.9-4 and include credits for the fertilizers formed ( $\$ 15 /$ ton of fertilizer, as compared with current costs of $\$ 90 /$ ton of fertilizer).* The E-beam scrubber is seen to have substantially lower capital and operating costs than the lime scrubber. For further details, we refer to Appendix AB-6, especially the paper by V. H. Shui and K. Kawamura.

Table 1.9-4 Cost comparison between the limestone scrubber and the AVCO/Ebara E-beam dry scrubber; reproduced from Appendix AB-6. The costs are based on EPRI guidelines.

\begin{tabular}{|c|c|c|}
\hline \multirow{3}{*}{ Total Capital Costs } & AVCO/Ebara & Lime Scrubber \\
\hline & $\$ 43 \times 10^{6}$ & $\$ 60 \times 10^{6}$ \\
\hline & $\$ 86 / \mathrm{kW}_{\mathrm{e}}$ & $\$ 120 / \mathrm{kW}_{\mathrm{e}}$ \\
\hline Other costs & \multicolumn{2}{|c|}{ Cost contribution, mills $/ \mathrm{kW}_{\mathrm{e}}-\mathrm{hr}$} \\
\hline Fixed charge & 3.3 & 4.7 \\
\hline $\begin{array}{l}\text { Operating and main- } \\
\text { tenance costs }\end{array}$ & 2.5 & 2.9 \\
\hline Reheat cost & 0 & 0.9 \\
\hline $\begin{array}{l}\text { Byproduct charge/ } \\
\text { (credit) }\end{array}$ & $(0.6)$ & 0.4 \\
\hline Total & 5.2 & 8.9 \\
\hline
\end{tabular}

ii. Flue-Gas Desulfurization

The most widely used commercial treatment for $\mathrm{SO}_{\mathrm{x}}$ control involves flue-gas desulfurization. Current research has emphasized the development of low-cost, regenerable $\mathrm{SO}_{2}$ absorbents. 57 Examples of liquids considered for this purpose are the following: citric acid, glycolic acid, 1-methy1-2-pyrrolidone,

*An EPRI-funded design and costing study is in progress at Bechtel. 
ethelenediamine, diethylenetriamine, tri-n-butyl phosphate, and 1-methy1-2-pyrrolidone. For $\mathrm{SO}_{2}$ absorption followed by indirect steam stripping, a $9.75 \%$ ethylenediamine solution was found to have the lowest steam rate among the listed absorbents. However, absorbent stack losses were so high that amines with higher boiling points will have to be used in practice. 57

A sulfur abatement program has been proposed for Europe with an estimated price tag of about $\$ 580 \times 10^{6} / \mathrm{yr}$ or about $2 \%$ of estimated annual European expenditures on energy. ${ }^{58}$

Advanced clean-up systems for PFBCs are under development by METC. 59

\section{iii. ASPEN}

The ASPEN (Advanced System for Process Engineering) is a detailed system for modeling to improve designs. It was developed at MIT, completed during 1982 and transferred to METC-VAX installations for applications by industrial users groups. The initial applications refer to cold gas clean-up in gasification. A model is under development for 6 hot PFBC clean-up concepts. The reference $P F B C$ system has a cyclone clean-up unit.

A flow diagram of the ASPEN installation is shown in Fig. 1.9-2. Reference to this figure suggests the extent of required, process-related input data that will be needed if the ASPEN approach is to yield meaningful cost estimates. Significant verification of ASPEN will require extensive empirical testing, as well as comparisons with another simulation model developed at the General Electric Co. The PFBC plant simulation includes over 100 unit-operation blocks ${ }^{59}$ and is hopefully sufficiently detailed to predict the effects of small changes in operating conditions. The program tracks the vapor-phase chemical compositions (including $\mathrm{SO}_{2}$ and $\mathrm{NO}_{\mathrm{x}}$ ), as well as fly ash, char, spent dolomite, and the solid particle-size distribution. Steam side simulation includes the main heater, reheater, turbines, condenser, water heater, and other components. 


\section{REFERENCES}

1. 'Utilization AR\&TD Contractors' Review Meeting on Pulverized Coa1 Combustion," March 4-5, 1982, Pittsburgh Energy Technology Center, Pittsburgh, Pa.

2. C. R. Bozzuto, CCAWG meeting in La Jo11a, May 28, 1982, Appendix $A B-2$.

3. J. C. Holmes, Jr., "The Effect of Coal Quality on the Operation and Maintenance of Large Central Station Boilers," paper presented at the 1969 Annual Meeting of the American Institute of Mining, Metallurgical and Petroleum Engineers, Washington, D.C.

4. R. E. Barrett et a1, "Examining Relationships Between Coal Characteristics and Performance of TVA Power Plants," Interim Report, TVA, November 1980.

5. The Hoffman-Muntner Corporation, "Effect of Coal Quality on Maintenance Costs at Utility Plants," Report DOE/ET/12512-1, June 1980.

6. G. C. Thomas, W. H. Clayton, and V. LIinares, Jr., "C.-E. Availability Data Program," Proc. Am. Power Conf., vol. 42 , Chicago, Ilinois, April 1980.

7. J. M. Beér, "Choice of Coal Preparation Systems for Pulverized-Fue1-Firing," Engineering and Boiler House Review, pp. 1-6, September 1959 .

8. M. G. McGraw, "Plant-Site Coal Hand1ing," Electrical World, pp. 63-94, July 1982 .

9. W. Nusse1t, V.D.I. $\underline{68}, 124$ (1924).

10. R. H. Essenhigh and J. Csaba, "The Thermal Radiation Theory for Plane Flame Propagation in Coal Dust Clouds," Ninth International Combustion Symposium, pp. 111-125, The Combustion Institute, Pittsburgh, Pa., 1963.

11. M. A. Field, D. W. Gill, B. B. Morgan, and P. G. N. Hawksley, "Combustion of Pulverized Coal," The British Coal Utilzation Research Association,

1967.

12. L. D. Smoot, "Pulverized Coal Diffusion Flames: A Perspective Through Modeling," Eighteenth International Combustion Symposium, pp. 1185-1202, The Combustion Institute, Pittsburgh, $\mathrm{Pa} ., 1981$. 
13. International Symposia on "Coal Slurry Combustion;" reports are available from the Pittsburgh Energy Technology Center, Pittsburgh, Pa., 1979 (First Symposium), 1980 (Second Symposium), 1981 (Third Symposium), 1982 (Fourth Symposium).

14. J. M. Beér, W. F. Farmayan, C. Gabriel, M. Togan, S. Srinivasachar, and L. Monroe, "Combustion, Heat Transfer, Ash Deposition, and Pollutant Emission Characteristics of COM," in Ref. 4, 1982 .

15. For a recent overview of this important field, see Physical Cleaning of Coal, 551 pages, Y. A. Liu ed., Marcel Dekker, Inc., New York, 1982 .

16. R. S. Scheffee, E. G. Skolnik, N. P. Rossmeissl, H. L. Heaton, and E. T. McHale, "Further Development and Evaluation of CoalWater Mixture Technology," in Ref, 13, 1982.

17. J. H. EcKmann, "Transport and Handling Characteristics of Coal Water Mixtures, Orlando, F1a. (May 1982).

18. E. T. McHale, R. S. Scheffee, and N. P. Rossmeisse1, Combustion and Flame 45, 121 (1982).

19. Y. S. Pan et a1., "Exploratory Coal-Water and Coa1-Methano1 Mixture Tests in Oil-Designed Boilers," 4th International Symposium on Coal Slurry Combustion, Orlando, Fla. (May 1982).

20. EPRI Report of Joint B\&W/EPRI study,

21. R. S. Scheffee et al, see Ref. 16, 1982.

22. S. Drenker (EPRI), CCAWG meeting at METC (July 15, 1982), Appendix $A B-4$.

23. R. L. Gamble, "Industrial Fluidized Bed Steam Generation," ASME Paper 81-IPC-FU-2, The American Society of Mechanical Engineers, 345 E 47 th Street, New York, NY 10017.

24. W. Wolowodiuk, CCAWG meeting at METC (July 15, 1982), Appendix AB-4.

25. J. M. Beér and others, CCAWG meeting at METC (July 15, 1982), Appendix AB-4.

26. A. Robertson, CCAWG meeting at Foster Wheeler (December 9, 1982), Appendix AB-9-1. 
27. S. Moskowitz, CCAWG meeting at Foster Wheeler (December 9 , 1982), Appendix AB-9-2.

28. V. Zakkay, CCAWG meeting at Foster Wheeler (December 9, 1982), Appendix $A B-9-3$.

29. S. Moskowitz and J.F. Geffken, AIAA-81-0392, "Pressurized Fluidized Bed-A Technology for Coal-Fired Combined Cycle Power Generation," AIAA Aerospace Sciences Meeting, January 12-15, 1981, St. Louis, Mo.

30. CCAWG meeting at the Babcock and Wilcox Research Center (October 18, 1982), Appendix AB-8.

31. See Appendix AB-10 for details.

32. See Appendix $A B-5$ for details.

33a. J. C. Corman, "Integrated Gasification Combined Cycle Experimental Simulation," paper presented at the Eighth Energy Technology Conference and Exposition, Sheraton Park, Washington, D.C., March 9-11, 1981.

33b. T. D. Brown, "Coal Gasification-Combined Cycles for Electricity Production," Progr. Energy Combust. Sci. 8, 277-301 (1982).

34. K. E. Yeager, "Technical Advances in Coal Utilization," paper presented at the First U.S.-China Conference on Energy, Resources and Environment, Beijing, November 1982.

35. Physical Cleaning of Coal, edited by Y. A. Liu, Marcel Dekker, Inc., New York and Base1, 1981.

36. CCAWG meeting at Foster Wheeler (December 9, 1982), Appendix $A B-9-6$.

37. See Appendix AB-10-1 for details.

38. See the CCAWG meetings at Combustion Engineering (June 23, 1982, Appendix $A B-3)$ and at the Babcock and Wilcox Research Center (October 18, 1982, Appendix AB-8), as well as selected appendices in subsequent CCAWG site-visit reports.

39. C. L. Wagoner, "The Second-Generation Laboratory Ashing Furnace," Proceedings of the Engineering Foundation Conference, July 1981 .

40. C. L. Wagoner and G. Haider, "Preliminary Observations of the Influence of Fireside Deposition on Ion-Exchangeable Calcium in Coal," Conference of The Engineering Foundation, White Haven, $\mathrm{Pa}$, October 31-November 5, 1982 .

41. F. R. Burkhardt and M. M. Persinger, "Economic Evaluation of Losses to Electric Power Utilities Caused by Ash Fouling," Contract DE-AC18-79FC10059, The Virginia Corporation of Richmond, 5809 Lakeside Ave., Richmond, Va. 23228, 1 November 1979, 30 Apri1 1980. 
42. F. R. Burkhardt and M. M. Persinger, "Economic Evaluation of Losses to Electric Power Utilities Caused by Ash Fouling," The Virginia Corporation, Richmond, Va., DOE Contract No. AC18-79FC10059, Report DOE/GFETC/10059-2, December 1980 .

43. T. E. Buschek, R. T. Smith, and M. W. Burr III, "Economic Evaluation of Alternative Solutions to Decrease Boiler Ash Fouling," Energy Resources Co./California, Walnut Creek, Ca., Report DOE/FC/10232-T1, Contract AC18-80FC10232, October 1981.

44. L. D. Smoot, G. J. Germane, J. N. Cannon, and L. C. Trost, "Pulverized Coal Power Plant Fires and Explosions," Combustion Laboratory, Brigham Young University, Provo, Utah 84602,1978 .

45. J. L. Elder, L. D. Schmidt, W. A. Steiner, and J. D. Davis, "Relative Spontaneous Heating Tendencies of Coals," Technical Paper 681, U.S. Bureau of Mines, Pittsburgh 1945; this publication was available through the U.S. Government Printing Office, Washington, D.C., 1945.

46. L. W. Needham and N. W. Ha11, "The Shape and Specific Surface of Coal Particles," Fuel 14, 222-30 (1935).

47. L. D. Schmidt, Chapter 18 in Chemistry of Coal Utilization (H. H. Lowry, ed.), John Wiley and Sons, New York, 1945.

48. E. A. C. Chamberlain and D. A. Hall, "The Liability of Coals to Spontaneous Combustion," Colliery Guardian, pp. 65-72, February 1973; ibidem, "The Practical Early Detection of Spontaneous Combustion," ibid., May 1973.

49. E. A. C. Chamberlain, "Spontaneous Combustion of Coal," Colliery Guardian, pp, 79-82, March 1974.

50. F. L. Shea, Jr., and H. L. Hsu, "Self-Heating of Carbonaceous Materials," Ind. Eng. Chem. Prod. Res. Dev. 11, $184-187$ (1972).

51. H. S. Wilson, "An Update on Coal Storage Technology," Combustion, pp. 33-36 (1975).

52. M. Hertzberg, K. L. Cashdollar, and J. J. Opferman, "The Flammability of Coaldust-Air Mixtures," Report 8360, 70 pages, U.S. Dept. of Interior, Bureau of Mines, Pittsburgh, Pa., 1979; ibidem, "The Limits of Flammability of Pulverized Coals and Other Dusts," Eighteenth Symposium (International on Combustion, pp. 717-729, The Combustion Institute, Pittsburgh, Pa., 1981. 
53. Workshop on "Coal Dust Fire and Explosion Hazards in Cement Plants, and Other Surface Facilities," sponsored by the U.S. Bureau of Mines/PETC and held in Denver, Colorado, April 1982 .

54. See L. D. Smoot and others, CCAWG meeting at Combustion Engineering (June 23, 1982), Appendix AB-3.

55. CCAWG meeting at METC (July 15, 1982), Appendix AB-4. The principal contributions were made by the following METC staff members: J. Halow, J. Williams, K. E. Marte1, Jr., K. Castleton, and L. Hadley.

56. K. Kawamura and V. H. Shui, "Radiation Treatment of Exhaust Gases for $\mathrm{SO}_{2}$ and $\mathrm{NO}_{\mathrm{X}}$ Removals," International Atomic Energy Agency, International Conference on Industrial Application of Radioisotopes and Radiation Technology, Grenoble, France, September 28-October 2, 1981.

57. R. J. Walker, C. H. Schwartz, D. J. Wildman, and S. J. Gasior, "Evaluation of Some Regenerable Sulfur Dioxide Absorbents for Flue-Gas Desulfurization," DOE, PETC, 1982.

58. N. H. Highton and M. J. Chadwick, "The Effects of Changing Patterns of Energy Use on Sulfur Emissions and Depositions in Europe," Ambio 11, 324-329 (1982).

59. L. Hadley in Appendix $A B-4$. 


\section{CHAPTER 2}

\section{CCAWG RED RECOMMENDATIONS RELATING}

TO DIRECT COAL UTILIZATION

In this chapter, we summarize R\&D recommendations relating to coal-utilization technologies after commenting briefly on the general problem area of costing and commercialization of fossilfuel technologies. There are very many studies that should be performed in order to improve our understanding and the efficiencies with which coal is utilized. While fundamental work is in progress, the level of effort is generally not commensurate with the needs for rapid development and commercialization.

The following problem areas were selected for special emphasis at a later conference because adequate synthetic summaries were considered to be unavailable: the relation of coal combustion to combustion behavior; the relation of mineral composition to slagging, fouling and erosion during and after combustion; fluid dynamic processes in coal combustion; diagnostic techniques applied to coal-combustion processes; coal preparation, comminution and feeding into coal combustors. The conference proceedings (CCAWG Conference, La Jo11a, CA, August 24-25, 1983) covering the specified six topical areas will be published at a later date. 


\section{$2.1 \quad$ Costing and Commercialization}

\subsubsection{Overview}

Studies supported by DOE, NASA, EPRI and others during the past 10 years have shown that the capital cost of a coal-fired power plant, given a common site, is approximately the same (within $\pm 10 \%$ ) for different coal-application technologies. Because of the rapid escalation in costs for all utility-related equipment during this same time period, the industry tends to be very cautious about accepting cost estimates for new technologies that were produced as a result of paper or small-scale studies. The industry is also keenly aware of the difficulties involved in pioneering a first-ofa-kind plant. In addition, intense regulatory pressure and weak financial conditions tend to force the utility industry to apply proven technology. As a result, advances in technology tend to be evolutionary rather than revolutionary. Introduction of new technologies from the laboratory stage to significant market penetration has traditionally required on the order of 50 years. Table 2.1-1 shows introduction schedules for some representative energy technologies.

Table 2.1-1 Introduction schedules for selected energy technologies.

\begin{tabular}{|l|c|c|c|c|}
\hline Application stage & $\begin{array}{c}\text { Steam } \\
\text { Turbine }\end{array}$ & $\begin{array}{c}\text { Nuclear } \\
\text { power }\end{array}$ & $\begin{array}{c}\text { SO }_{2} \\
\text { scrubbers }\end{array}$ & $\begin{array}{c}\text { Industrial } \\
\text { AFBC }\end{array}$ \\
\hline Laboratory stage & $1870 \mathrm{~s}$ & $1930 \mathrm{~s}$ & $1930 \mathrm{~s}$ & 1955 \\
\hline Pilot plant & $1882-86$ & 1941 & 1935 & 1970 \\
\hline Demonstration & 1895 & 1953 & 1966 & 1977 \\
\hline First commercial unit & 1900 & 1955 & 1968 & 1980 \\
\hline $\begin{array}{l}\text { Significant } \\
\text { market penetration }\end{array}$ & 1905 & 1965 & 1978 & $?$ \\
\hline $\begin{array}{l}\text { Penetration to 10\% } \\
\text { of existing capacity }\end{array}$ & 1910 & 1978 & 1980 & $?$ \\
\hline
\end{tabular}




\subsubsection{Research Recommendations}

Attempts to accelerate the introduction of new technologies have generally been unsuccessful. In particular, federal intervention in the market place has not proved to be an effective process for commercializing new systems. For this reason, we believe that support by federal agencies should preferably be restricted to fundamental research and development with potential long-term significance in developing technological areas. 
2.2

Coal Preparation

\section{2 .1 Overview}

Attitudes towards the necessity for coal preparation and beneficiation differ among representatives of electric utilities, DOE, other countries, or scientists and engineers who are not specialists in coal utilization. U.S. boiler manufacturers change the spacing of boiler tubes and introduce other modifications to handle uncleaned coals in preference to coal preparation and the use of smaller boilers. While the amount of coal cleaned in the U.S. has been declining slowly (in 1974, $51 \%$ of U.S. coal was cleaned; in 1982, on $1 y$ 41\% of coal was cleaned), it is now generally believed that more coal will be cleaned in the future. There is currently increasing use of low-rank, strip-mined coal, of which about $1 \times 10^{6} \mathrm{TPY}$ were used in 1970 and more than $200 \times 10^{6} \mathrm{TPY}$ in 1981. The reduction in steel production has contributed to the decline in cleaned coal use, since all metallurgical coal is cleaned. The cleaning of Eastern steam coal is not declining. We are just beginning to apply coal-preparation techniques to lowrank coal. The TVA utilizes total washing to reduce the ash contents to $\sim 8-10 \%$. Data are available on the amounts of coal cleaned in 1974 in various countries. * The following percentages of coal were cleaned during 1974 in major coal-producing countries: U.S., $51 \%$; Australia, where large amounts of brown coal have been mined, $54 \%$; Belgium, $89 \%$; Canada, $64 \%$; Germany, $49 \%$, with $45 \%$ of the total coal hand-picked from run-of-mine coal; Great Britain, $87 \%$; India, $16 \%$, with $80 \%$ of total coal hand-picked; Japan, $95 \%$; The Netherlands, $81 \%$; Poland, $48 \%$; South Africa, $48 \%$.

The following are some of the benefits of coal preparation: (i) sulfur and ash contents are reduced; (ii) the carbon is

"International Coal Preparation Conference Proceedings, Australia, 1976. 
concentrated; (iii) trace-element concentrations are lowered; (iv) a product of more uniform quality is produced; ( $v$ ) pollutants are decreased; ( $v i$ ) increased heat contents obtain for the cleaned coal per unit mass; ( $v i i)$ there are transportation savings because less weight is shipped for the same BTU contents; (viii) there are cost savings in coal comminution because less cleaned coal is pulverized for the same BTU contents; (ix) the boiler and related equipment last longer because clean coal is less corrosive; $(x)$ ash disposal cost savings occur because clean coal forms less ash.

While the inherent ash contents in coal are only changed slightly by coal washing, the extraneous mineral matter, which is noncombustible, is extensively removed during coal preparation. Removal of the mineral matter greatly reduces ash fusibility.

Large percentages of shale are readily separated from coal by using conventional gravity-separation methods. The shale consists primarily of silica and alumina; removal of these materials lowers the fusion temperature of the remaining coal ash. Calcite and dolomite may also be present as large, discrete particles; their remova1 raises the ash-fusion temperature since these minerals are effective fluxes for coal ash. Mineral matter rich in iron compounds, other than marcasite or pyrite, as well as compounds of potassium and sodium, may be removed during coal preparation, thus raising ash fusibility. Each coal presents special problems insofar as ash fusion is concerned. Since 1976, EPRI has supported work at Battelle that is aimed at relating the occurrences of mineral forms in coal to fouling and slagging behavior in large utility-boiler furnaces. Washability curves alone do not provide information on the behavior of the ash in washed coal during combustion.* Cost savings in $\$ / T$ for firing a cleaned coal in a utility

\footnotetext{
"W. T. Reid, "Coal Ash - Its Effect on Combustion Systems," in Chemistry of Coal Utilization, p. 1389 , Second Supplementary Volume, Chapter 21, ed. by M. A. Elliott, Wiley - Interscience, New York, 1976.
} 
boiler have been summarized as follows: ${ }^{*}$ reduction in ash disposal cost, $\$ 0.25$; reduction in coal transport costs, $\$ 0.58$; reduction in maintenance costs, $\$ 1.73$; increase in peaking capacity, $\$ 3.23$; increase in plant availability, $\$ 1.32$; these estimates correspond to total savings of $\$ 7.11$ per ton of coal used.

Utilities burn coal with an average of about $13 \%$ ash. Reduction to $6-8 \%$ ash is generally considered to be desirable. There is environmental concern about relatively volatile-metals such as $\mathrm{Hg}, \mathrm{Cd}$, $\mathrm{As}$, and $\mathrm{Pb}$. Cleaning of coals would decrease the concentrations of these and of other trace metals.

U. S. coal use is characterized by a number of well defined problems: (i) Dewatering is a major problem that is increased as the percentage of fines is increased; coal-water slurries generally hold larger amounts of fines. (ii) Coal-preparation plants in the U.S. operate about 13 hours per day; in Germany, they operate 23 hours per day. As the result, capital investments in coal-cleaning operations are used less effectively in the U.S. than in Germany.

\subsubsection{Research Recommendations}

- There is a need to study surface phenomena of fine coals, which is well recognized by DOE as a problem area.

- Coal-fine trajectories in turbines should be estimated and verified experimentally.

- Non-aqueous solvents (e.g., fluorinated hydrocarbons, OTISCA) have been applied in coal cleaning but more work in this area is justified.

- On-1ine instrumentation is needed to measure compositions (e.g., ash, sulfur contents, and moisture) and to allow process control during coal cleaning.

- Physical methods to produce coals with $飞 1 \%$ ash are needed for oil backout.

*USAID ASEAN ENERgY 11, Coal Training Program, Jan. 31 - March 25 , 1983, Division of Educational Programs, Argonne, IL. 
- Disposal methods are urgently needed for fine refuse material derived from coal-preparation plants; improved techniques for fly-ash disposal are also desirable.

- Additional coal-characterization studies are needed to define washability, ultra-fine coal parameters, petrographic constituents, trace-element contents, mineral particle sizes, and degrees of association and ashing properties of coal blends.

- Improved understanding is desirable of the operation of froth flotation in coal cleaning, which is the only commercially available method for washing coal of minus 200 mesh. 
2.3 Safety in Coal Utilization, Comminution and Feeding

2.3 .1 Overview

2.3.1A Safety in Coa1 Utilization

Concern about safety in coal utilization is of long standing. In 1815, it led Sir Humphry Davy to the invention of the safety lamp for miners. In the $1880 \mathrm{~s}$, it provided major inspiration for Berthelot and Vieille in their work leading to the discovery of the detonation wave and also for Mallard and Le Chatelier in launching a comprehensive study of combustion phenomena that resulted in a classical paper (Annales des Mines, 1883), which is recognized today as one of the foundations of physical chemistry. These important pioneering studies were followed by a century of prolific research pertaining to ignitability, flammability, and combustion characteristics of a wide variety of fuels, including coal and its derivatives. Over the years, the US Bureau of Mines has been engaged in the acquisition and compilation of data that are of immediate practical interest in connection with studies on ignitability, flammability, and explosivity of coal-air mixtures.

In view of the enormous data base that has been compiled in this field and the current advanced state of knowledge, we believe that it would be beneficial to compile, codify, and interpret the scientific information acquired on this subject during the last century throughout the world.

Since the literature on safety is replete with misleading misnomers and to provide an idea of what may be needed, we list in Table 2.3-1 the essential elements of combustion phenomena pertaining to hazards. Column A shows various types of initiation processes and column $B$ the corresponding counteractions. Ignition is defined to be the initiation of a self-sustaining, exothermic process. This process is essentially homogeneous in nature; its progress is solely a function of time, not of space, and it is 
Table 2.3-1 Processes pertaining to hazardous combustion phenomena.

\begin{tabular}{|c|c|c|}
\cline { 2 - 3 } \multicolumn{1}{c|}{} & A & B \\
\cline { 2 - 3 } & Initiation & Annihilation \\
\hline 1 & Ignition & Extinction \\
2 & Inflammation \\
3 & Explosion & $\begin{array}{l}\text { Quenching } \\
\text { Decay }\end{array}$ \\
\hline
\end{tabular}

therefore proper to refer to it as auto-ignition. Inflammation is the initiation and propagation of a self-sustaining flame. It is essentially a diffusion process driven by the exothermicity of the combustion reaction, and its progress is therefore a function of both space and time. The word explosion refers to perhaps the most misused term in the combustion literature; it is usually a phenomenon manifested by a blast wave, which is an essentially non-steady flow (usually point-, line-, or plane-symmetrical), bounded by a gasdynamic discontinuity. The latter is either a shock or a detonation front.

As is evident from preceding comments, the most important and, at the same time, the most often disregarded parameter in any hazardous combustion phenomenon is time. The limits of hazard must involve a time-dependent parameter. In its simplest form, the threshold between safe and hazardous operations may be expressed in the manner illustrated in Fig. 2.3-1, which shows the rate and the amount of exothermic energy deposition in an exploding medium. The first of these may be expressed either in terms of power density or specific power (e.g., a rate of energy deposited per unit inass or per unit volume) and the second in terms of the corresponding energy 


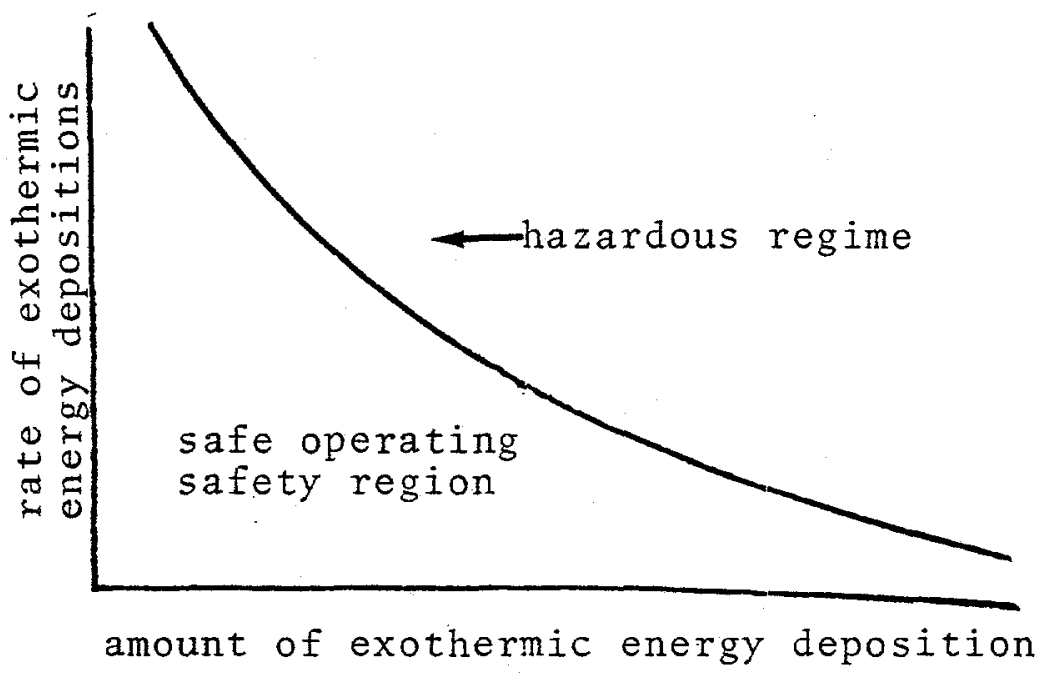

Fig. 2.3-1 Threshold between safe and hazardous regimes in terms of the rate and amount of energy deposition in an exploding medium.

density or specific energy.

For coal, one must take account of a variety of aging processes, as a consequence of which storage piles that are safe today may become hazardous in the future.

User demands for coal-safety characterization are usually expressed in terms time-independent ignitability or flammability limits and, notwithstanding their fundamental inadequacy, data of this kind are usually provided by government organizations (e.g., the US Bureau of Mines).

The science and technology of preventive measures are better understood and consequently more advanced than the definitions of hazard limits. In passive form, countermeasures may be provided by diluents; active countermeasures are inhibitors.

In summary, any kind of energy storage involves a hazard because of the possibility of its uncontrolled release. Thorough 
knowledge of the mechanisms whereby such releases take place and the means whereby they may be controlled or prevented from occurring will be of benefit to coal users. For this reason, a handbook on this subject, prepared and published under the auspices of the government, would be a useful contribution.

\subsubsection{B Safety in Comminution and Feeding}

The technology of coal comminution is well in hand. Its implementation is primarily a matter of the development of more economical means rather than that of improved science. Facilities available for this purpose are generally either mechanical or chemical in nature.

Among mechanical means for comminution and feeding are differential crushing in an impact (e.g., a hammer) mill, followed by screening; this technique is most effective on coals whose natural grain is smaller than the size of the contained pyrite. Impact crushing of coal that contains pyrite in very thin bands is used to break up these bands and produce pyrite fragments that are finer than the bulk of the coal particles. Differential grinding of coals, consisting of evenly distributed fine pyrite particles, is accomplished in a tumbling- or bowl-mill. Stage crushing or grinding involves a series of comminution stages with progressively finer feed.

Chemical comminution is based on the use of reagents to permeate and fragment the coal along its cleat boundaries, thereby producing fewer fines in the liberation of impurities than mechanical grinding. It is a promising concept and offers the attractive potential of combining comminution with cleaning and beneficiation. Its operating characteristics involve spontaneous fragmentation, which results from the diffusion and chemical action of a reagent along the grain boundaries and yields liberated pyrite and mineral matter in a product containing fewer fines than it would have if 
the liberation of impurities were attained by mechanical grinding. The extent of fragmentation by chemical comminution determines the degree to which impurities are liberated. Fragmentation extent and rate are governed by coal characteristics (e.g., the nature of the cleat system, original size, rank, porosity, moisture content), the reagent used, and operating conditions such as temperature and pressure.

Ammonia has been found to be the most effective reagent so far, possibly because, in comparison to other reagents (e.g., methanol) tested, it is of smaller molecular size. Since the kinetics of chemical comminution are diffusion-limited, the molecular size of the reagent is expected to play a significant role. Because chemical comminution selectively fragments coal along boundaries defined by the cleat system and bedding planes, its products contain much lower percentages of fines than those resulting from nonselective mechanical crushing. This aspect of chemical cleaning is advantageous for subsequent separation processes.

The rudiments of plant-site coal handling and feeding have been presented recently in quite a comprehensive manner by $M$. G, McGraw (Electrical World, pp. 63-94, July 1982). This article contains a succinct description of modern coal-handling systems, including a fairly detailed survey of facilities for unloading stations, coal-transfer conveyers, measuring and testing plants, intermediate storage stations including silos and bunkers, stockpile construction, as well as reclaiming, blending, dust-collecting and suppressing techniques, means for monitoring and minimizing the hazards of explosion, novel developments in transportation and feeding systems, and the management of coal-handling installations.

The problems of coal comminution and feeding are adequately addressed by industry and represent substantial current activities, as is manifested by a recent paper of R. C. Rittenhouse (Power Engineering, pp. 42-50, March 1983) on upgrading and maintenance of coal-handling equipment. 


\subsubsection{Research Recommendations}

- We recommend government sponsorship for the preparation of an authoritative handbook dealing with safety in coal utilization.

We find that research on safety has progressed far and that industry support for problems dealing with comminution and feeding is adequate for current and foreseeable needs. Nevertheless, the following types of studies appear to be well justified:

- Fundamental research should be performed on the flows of finely ground coals under pressure gradients as functions of carrier gas compositions, coal sizes, and coal-particle shapes.

Fundamental combustion research should also be supported in each of the following areas:

- Studies on turbulent coal-laden flames, on transition from deflagration to detonation in such two-phase systems, on the connection between dust explosions and propagating flames.

- The presently uncontrolled nature of dust explosions and fires in utilities must be better understood in order to implement effective control measures. 


\section{4 .1 Overview}

Research on fireside deposition has been divided between fouling of convective heat transfer surfaces and slagging of radiative surfaces. In spite of about 60 years of experience with pulverized fuel combustion, generalized predictive correlations are not available today which can relate coal characteristics to specific steam generator design and operational parameters. When coal is beneficiated, micronized, or slurried with water or oil, the existing empirical correlations, which were developed for pulverized coal, may provide very misleading information. For example, the behavior shown in Fig. 2.4-1 for the cleaned coal was not predictable using the improvement in the calculated slagging index based on elemental coal-ash analysis, the significant reductions in ash, total sulfur and pyritic sulfur levels, or the small increase in coal ash-fusion temperatures. Although the measured slag deposition rate was only one-fourth as great for the cleaned coal, the slag was liquid and had the potential to produce severe cleaning problems in a steam generator.

While sub-scale combustion tests usually provide information on deposition rates, more data are required to describe fouling and slagging adequately in terms of heat and mass transfer. Measurements would ideally show the net effect of material adhering during ash deposition and removal cycles in terms of changing values of heat flux, emissivity, thermal conductivity, etc., as a function of time, sootblowing medium and peak impact pressure. Also, specific local conditions would be measured and reported to aid in relating sub-scale data to utility boiler designs.

Complementary measurements should be made in utility boilers to describe fouling and slagging quantitatively in terms of heat transfer and heat rate over a range of boiler loads. 


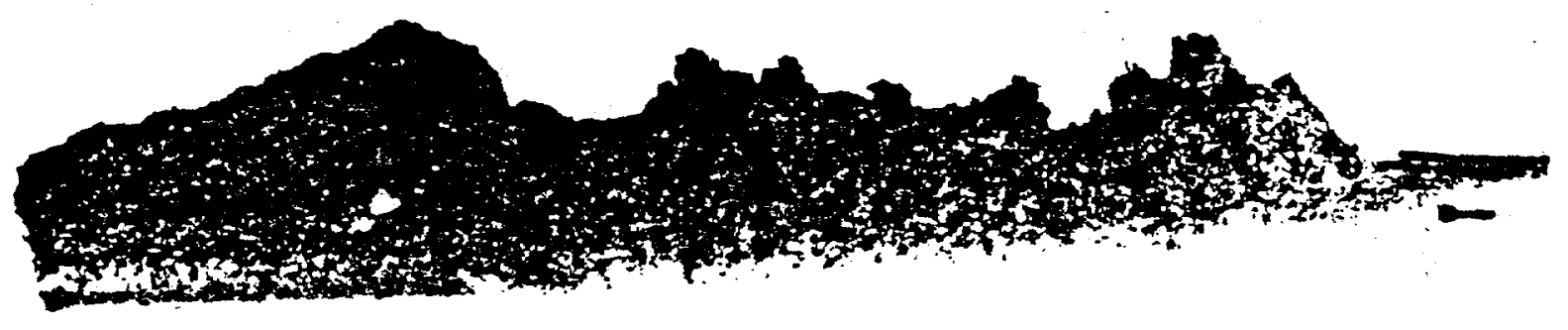

(a) Deposits from ROM coal.

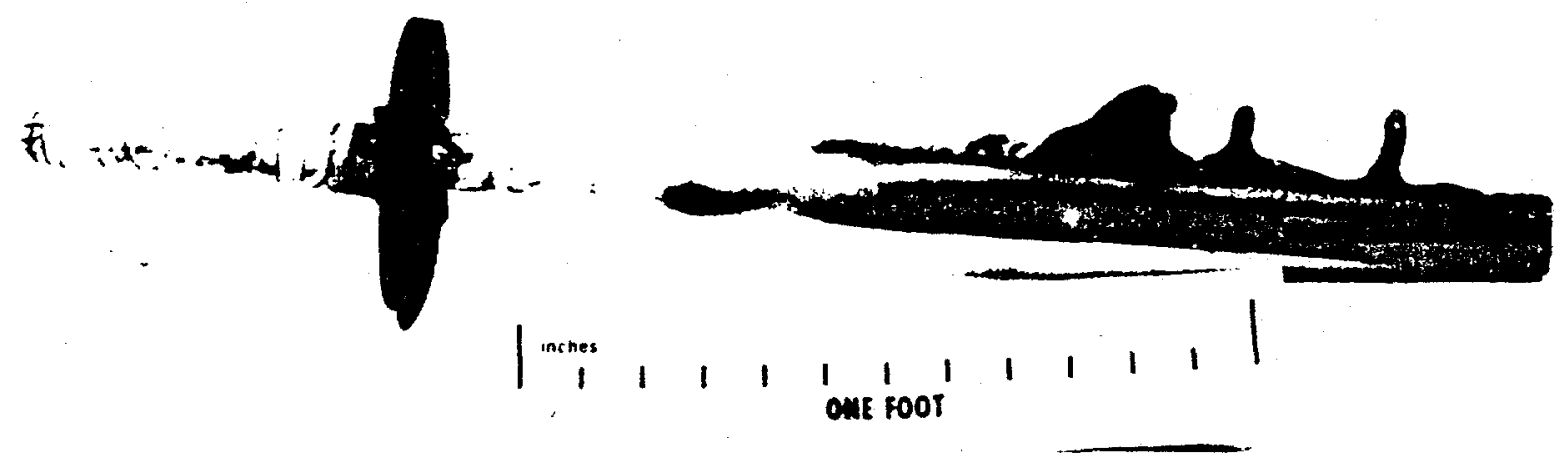

(b) Deposits from cleaned coal.

Fig. 2.4-1 Slag deposits formed in a sub-scale pulverized fuel combustion test. 


\subsubsection{Near-Term Research Recommendations}

The following two recommendations relate to the identified research needs and are considered by CCAWG to be highpriority near-term items which must be completed before fouling and slagging can be studied effectively:

- Develop a generic and quantitative procedure for measuring fouling and slagging directly as functions of heatand mass-transfer effects in full- and sub-scale tests.

- Develop procedures to relate sub-scale measurements to specific local conditions in full-scale tests.

It is recognized that this work represents a major effort and a significant cost. However, the rewards could be substantial. Currently, the electric utility industry is faced with a typical loss of about $\$ 2 \times 10^{6} / \mathrm{yr}$ in the operation of a $400 \mathrm{MWe}$ plant because of loss-of-boiler availability due to slag-related problems. If this loss could be minimized by more effective matching of fuel, boiler design, and operation, worthwhile savings would result. In addition, the risks would be minimized for premature failures associated with the use of new fuels (beneficiated, micronized, or slurried coals) because of unanticipated but unnecessary deposition limitations that might be observed during critical evaluation stages.

\subsubsection{Long-Term Research Recommendations}

Ultimately, fouling and slagging must be related to elementary processes involving coal composition, fluid dynamics of coal-conversion units, combustion rates and mechanisms, wall properties, radiative and convective heat-transfer rates, etc. A 
full understanding of the interplay of the physicochemical and flow processes that lead to fouling and slagging is a most challenging long-term research program.

- We recommend that the required long-term commitment be made by DOE to gain a fundamental understanding of the important mechanisms that are involved in fouling and slagging under diverse conditions and for different types of coals. 


\section{$2.5 \quad$ PC Boilers}

\subsubsection{Overview}

Pulverized-coal combustors have been discussed in Sec. 1.1, to which we refer for an overview of recent developments.

The prime areas of interest for continued development of pulverized coal-fired boilers relate to (i) improved unit availability, (ii) capital-cost reductions, and (iii) increased operating efficiency. These areas for process improvements are interrelated.

\subsubsection{Research Recommendations}

Research may be useful for the following purposes:

- materials for high temperature, high pressure service;

- diagnostics and instrumentation systems for process control and monitoring;

- improved maintenance techniques and systems;

- improved understanding of ash and mineral matter behavior;

- improved understanding of local combustion phenomena;

- improved welding and manufacturing techniques;

- heat-rate improvements;

- improved integration of plant systems.

All of these listed topical areas are dealt with in greater detail elsewhere in this report since they relate also to improvements and implementation of advanced coal-combustion technologies. 


\subsection{Atmospheric Fluidized Bed (AFB) Combustion}

\section{6 .1 Overview}

AFB combustion is an emerging technology, which is commercial* in industrial-sized and on the threshold of commercialization in utility-sized steam generators. Previous DOE funding on AFB combustion has accelerated commercialization. While it has been said that the Rivesville project impeded the development of AFB combustion for steam generation, experts close to the program have concluded that commercialization was actually accelerated by the Rivesville project.

Because of its historical importance, we comment briefly on the Rivesville project. The prime contractor for this DOE program was Pope, Evans and Robbins, Inc., with Foster wheeler Energy Corporation (FWEC) as subcontractor. The project was sited at an existing power plant of the Monongahela Power Company (MPC). At the time of inception of the project, there was 1ittle interest in an industrial scale AFB. The largest AFB in operation was a $9-f t^{2}$ test unit. MPC offered a facility that was far from ideal and required a 60:1 scale-up. It was therefore inevitable that problems would develop. The primary difficulties in the system were associated with the materials handling and other plant services that have been described as antiquated. The system did achieve its full design operating steam capacity of $300,000 \mathrm{lb} / \mathrm{hr}$. Although it was frequently misoperated and suffered from failures in auxiliary system reliabilities, it spawned numerous other fluidized bed programs. Knowledge gained from operation of the Rivesville unit was incorporated in improved designs of subsequent units.

*For example, Foster Wheeler Energy Corporation had 11 domestic and 18 foreign orders for AFB units during early 1983. The steam capacities of these units ranged from 17,000 to 300,000 $\mathrm{Ib} / \mathrm{hr}$. 
According to experts at FWEC, the low freeboard height was responsible for an air-heater fire at Rivesville because of operating errors. The unit was designed with numerous inbed feed points and had small-diameter tubes penetrating the sides to points at the centers of equal areas throughout each of the beds. Cell $\mathrm{C}$ was the source of the problem leading to a fire. This bed had 12 tubes, 6 entering from each side; 3 of the tubes were of we11 defined length and aligned at a particular angle and 3 others were about one third shorter and aligned at another angle. Contrary to FWEC recommendations, the longer tubes were shortened so that a11 6 tubes terminated at the same point. Prior to the fire, coal was fed only from one side, thus resulting in a concentration of fuel along a line in the bed. Operation in this mode continued, although the co meter for the bed continually read off-scale. After the fire, considerable deposits of coke were found in the in-bed and freeboard sections of Cell $\mathrm{C}$, thus confirming the poor conditions for combustion that had occurred. Cell $\mathrm{C}$ had been operated as a gasifier for some period of time prior to the fire; volatile material and condensable gases had cooled and condensed within the air heater, thereby providing a source of fuel to initiate the fire. Air-heater fires are not common occurrences. When they do occur, they are often caused as the result of combustibles collecting on surfaces.

For further descriptions of important features of atmospheric fluidized bed combustors and their developments, we refer to Sec. 1.3. Here, we content ourselves with summary statements on research recommendations.

\subsubsection{Research Recommendations}

The following areas of basic research on conventional bubbling beds are recommended advisedly. Even while commercial developments are proceeding, we may anticipate improvements in 
both reliability and performance from the following work:

- Both in-bed and over-bed coal feeding processes should be studied.

- The complex processes governing bed dynamics are inadequately understood. In particular, the mechanisms of particle entrainments and movements, the locations and functioning of drains, and elutriation from the freeboard should be investigated.

- The following aspects of bed kinetics require investigations: $\mathrm{SO}_{\mathrm{x}}$ removal, $\mathrm{NO}_{\mathrm{x}}$ reduction, mechanisms and rates involving hydrocarbons and $\mathrm{CO}$, removal of HCl.

- Transient bed operations lead to special problems that require examination.

- Elutriations associated with fly-ash reinjection and fly-ash characterization are inadequately understood.

- Tube integrity requires improvements and the following aspects require further studies: design, performance and materials specification of waterwall tubes, as well as oxidation, sulfidation, corrosion, and erosion rates of in-bed tubes.

- Careful monitoring is needed of (low-grade) fuels and sorbents inventories and of sorbents enhancement.

- Improved understanding of fundamental processes involved in coal combustion (e.g., swelling, fragmentation, devolitilization, etc.) may contribute to improved AFB combustor designs, as well as to other coal-utilization techniques. Work on large particles should be emphasized. 
- Emission control is of critical importance in $A F B$, as well as in other coal combustion units. Each of the following topical areas requires improved understanding: $\mathrm{SO}_{2}$ capture, sulfation of $\mathrm{CaO}$, sorbents and additives to facilitate $\mathrm{SO}_{2}$ removal, regeneration of additives for $\mathrm{SO}_{2}$ capture; $\mathrm{NO}_{x}$ formation from fuel nitrogen, the effects of combustion-unit staging, reduction of $\mathrm{NO}_{\mathrm{x}}$ by $\mathrm{CO}$ and solid carbon in the freeboard.

- Particulate characterization and reinjection represent problem areas.

- The AFB air heater represents an important component that could perhaps be improved as the result of better closedcycle system designs, including designs of modular structures. 
2.7 Advanced Atmospheric and Pressurized Fluidized Bed (PFB) Combustion

\subsubsection{Overview}

PFB combustors have been described in Sec. 1.4, to which we refer for details concerning current developments of pilotand larger-scale testing. Unlike AFB combustors, these units are not yet commercially available, even for industrial-scale steam generators. However, with DOE support, successful commercialization may well be accomplished before the end of the current decade.

\subsubsection{Research Recommendations}

- Advanced AFB combustors may have controlled bed circulation. Mechanisms of differential fluidization (rolling) and operations of directional conveying grids require study. Corrosion and erosion problems may well be amplified in these designs and should be investigated.

- All of the needed studies noted for improving AFB combustors will be useful also for PFB combustors. Added emphasis should, however, be placed on the influence of bed depths and pressure levels on PFB performance and operating stability.

- Hot-gas clean-up should be studied up to temperatures of about $1750^{\circ} \mathrm{F}$. At higher temperatures, particulate removal becomes exceedingly difficult and turbine-blade corrosion will generally be excessive.

- Possible gains accruing from the use of lower operating temperatures should be carefully assessed and the current $800^{\circ} \mathrm{F}$ turbine-inlet program should be continued, as should be investigations on the utilization of selected cooling fluids. 
Coal-oil mixtures (COM) or slurries (COS) have been extensively discussed in Section 1.2E, to which we refer for details concerning especially the combustion RGD status.

\section{8 .1 Overview}

The market for conversion to COM consists of oil-fired utility and industrial boilers, blast furnaces and process heaters. Table 2.8-1 shows an estimate of market potential. There are 220 utility boilers built for coal which were converted to the combustion of oil with a total capacity of $30,165 \mathrm{MW}$, which would be the prime target for retrofitting because the combustion chambers and convective tube banks were designed to cope with coal ash. There are 245 additional boilers originally designed for oil use, which could also be retrofitted to burn COM but at the cost of some derating. In addition to utility boilers, industrial oil-fired boilers that may be retrofitted with COM represent a capacity of $35,619 \mathrm{MW}$. The preceding estimates of oil that may be displaced by the use of COM are based on a $40-$ to-60 coal-to-oil weight ratio in COM, $50 \%$ conversion of utility boilers, and $25 \%$ conversion of industrial steam-raising plants. The assessment of Table 2.8-1 shows that $386 \times 10^{3} \mathrm{BPD}$ of oil could potentially be replaced by the use of COM in existing oilor gas-fired boilers.

\subsubsection{A Historical Comments}

COM development has a history of more than 100 years. The first demonstration of COM combustion was made in Britain in 1879 and the first patent for utilizing COM was issued to H. R. Smith and H. M. Mansell in the U.S. at the same time. The British Submarine Defense Association performed sea-going COM 
Table 2.8-1 Estimated market potential (utility boilers $>50$ MW with 0.50 capacity factor and $50 \%$ market penetration; industrial boilers $>100 \times 10^{3} \mathrm{MJ}-\mathrm{hr}^{-1}$ with 0.35 capacity factor and market penetrations of $50 \%$ for coal-designed equipment, $25 \%$ for oil-designed boilers, and $50 \%$ for blast furnaces. The COM is assumed to have $40 \%$ of coal by welght. Reproduced from D. Bienstock and E. M. Jamgochian, "Coa1-0i1 Mixture Technology in the U.S.," Fue1 60, 851-864 (1981).

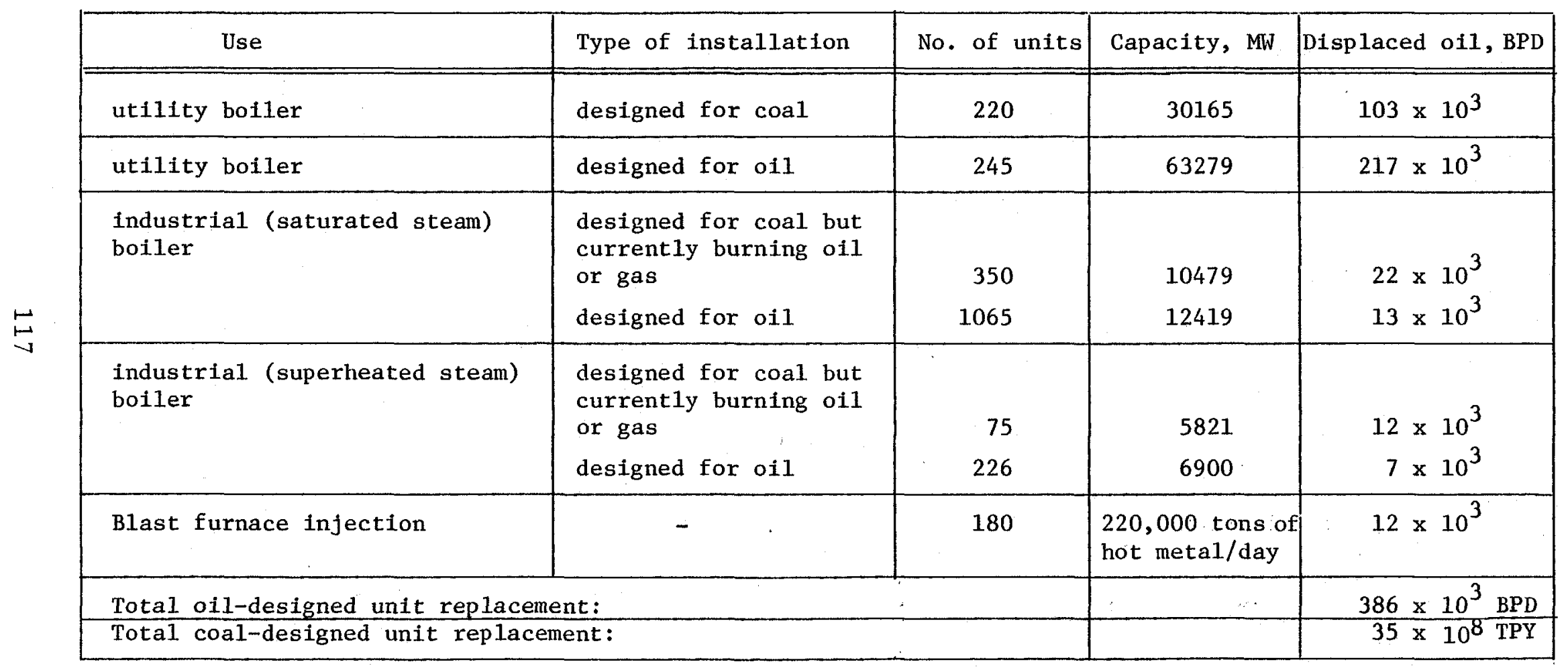


tests in a U.S. Navy Scout vessel fitted with a water tube boiler in 1918; the COM consisted of 33\% pulverized coal ground to below $76 \mu \mathrm{m}, 66 \%$ heavy fuel $0 i 1$, and $1 \%$ lime resin soap stabilizer. In the 1920s, tests were performed using COM in 1ocomotives of the Great Central Railway in England. Research and development of COM utilization continued with sporadic tests after the Second World War. In the sixties, COM was used successfully at the National Coal Board-Esso and the Bethlehem Steel Corporation in blast furnaces and experiments were carried out to determine rheological properties of ultrafine ( $4-5 \mu \mathrm{m})$ coal-oil slurries.

\subsubsection{B Completed Demonstration Studies}

A consortium of 26 companies and organizations sponsored tests in 1974 at the G.M. Chevrolet Nodular Iron Casting Plant Powerhouse using an oil-fired package boiler rated at $54.5 \mathrm{t} / \mathrm{hr}$ of steam. During the first phase of these tests, a mixture containing $35 \%$ coal by weight was burned for more than 250 hours. In the second phase, 494 hours of operation were obtained with $50 \%$ by weight of coal in the COM. These tests were not designed to show details of combustion characteristics of COM but rather to demonstrate the feasibility of burning COM in an industrial-size boiler.

Three major utility demonstrations have been completed more recently. An $80 \mathrm{MW}$ e plant (NEPSCO), a $383 \mathrm{MW}$ e plant (Florida Power Corporation) and a $400 \mathrm{MW}$ e plant (Florida Power and Light Company) were run for prolonged periods of time after minor alterations in existing boilers, which had been originally designed either for coal but converted to oil in the $1960 \mathrm{~s}$ (NEPSCO) or else were initially designed for oil use. In the largest of these boilers ( $400 \mathrm{MW}_{\mathrm{e}}$ ), 120 full burn days were achieved during a period of 12 months. After an initial period of exploratory tests, the boiler was on line with a COM containing 40-45\% coal 
by weight. Although slagging in the combustion chamber was quite heavy and it was noted that changes would have to be made in the convective section of the boiler for long-term operations, the tests were successfully concluded and no outage was reported. The demonstration experiment had to be stopped because of expir-

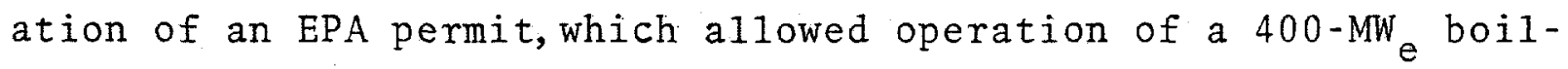
er without a gas-solid separator for a test period of only one year. Characteristic data of U.S. demonstration studies carried out in industrial and utility plants are summarized in Table 2.8-2.

In addition to the U.S. demonstration studies, tests of COM combustion in utilities and industrial steam-raising plants and blast furnaces were performed in several countries abroad. A feasibility study was carried out in Canada by the New Brunswick Electric Power Commission using a small 12.5-MW boiler and burning COM containing up to $40 \%$ of coal by weight. The Steel Company of Canada Limited (Stelco) is developing a COM injection systems for blast furnaces; their fuel contains coal, coke oven tar, creosote, and oil bottoms.

\subsubsection{Comparisons of COM and CWM}

We refer to Sec. 1.2E for an overview of technical problem areas and confine the following comments to comparisons of COM and CWM.

It is apparent that the two technologies involving COM and CWM are in competition for the same market, namely, retrofitting of oil-fired industrial and utility steam-raising plants. CWM replaces fuel oil completely, whereas COM replaces approximately $35 \%$ of the total input enthalpy. The ash contents of coal slurries are higher by more than one order of magnitude than those of the fuel oil they replace. The increased ash leads to accumulation of slag in the combustion chamber and fouling and erosion of convective heat-exchange surfaces of the 
Table 2.8-2 COM system characteristics and operating experience; reproduced from D. Bienstock and E. M. Jamgochian, "Coa1-0i1 Mixture Technology in the U.S.," Fuel 60, 851-864 (1981).

\begin{tabular}{|c|c|c|c|c|}
\hline Project & Application & $\begin{array}{l}\text { Combustor } \\
\text { capacity, } \mathrm{kg}-\mathrm{hr}^{-1}\end{array}$ & $\begin{array}{c}\text { Operation, } \\
\mathrm{hr}\end{array}$ & Status (1981) \\
\hline \multicolumn{5}{|l|}{ DOE supported tests } \\
\hline NEPSCO & $\begin{array}{l}\text { coal-designed utility } \\
\text { boiler (B\&W) }\end{array}$ & $283.5 \times 10^{3}(80 \mathrm{MW})$ & $\begin{array}{l}>1500 \\
(22 \text { wt. } \% \text { COM })\end{array}$ & $\begin{array}{l}\text { The use of higher coal } \\
\text { concentrations was lim- } \\
\text { ited by environmental } \\
\text { standards. }\end{array}$ \\
\hline GM consortium & $\begin{array}{l}\text { oil-designed indus- } \\
\text { trial boiler with } \\
\text { watertube (C. E. } \\
\text { Wickes) }\end{array}$ & $54.4 \times 10^{3}$ & $\begin{array}{l}250 \\
(35 \text { wt.\% COM }) \\
494 \text { wt.\% COM })\end{array}$ & $\begin{array}{l}\text { The project was com- } \\
\text { pleted in } 1977 .\end{array}$ \\
\hline PETC & $\begin{array}{l}\text { oil-designed indus- } \\
\text { tria1 boiler with } \\
\text { marine firetube } \\
\text { (cleaver Brooks) }\end{array}$ & $1.6 \times 10^{3}$ & $\begin{array}{l}3000 \\
(20-30 \text { wt. } \% \text { COM })\end{array}$ & $\begin{array}{l}\text { The project was comple- } \\
\text { ted in } 1979 ;{ }^{\text {a new } 1.6} \\
\times 10^{3} \mathrm{~kg}-\mathrm{hr}^{-1} \text { boiler } \\
\text { was then installed. }\end{array}$ \\
\hline & $\begin{array}{l}\text { oil-designed indus- } \\
\text { trial boiler with } \\
\text { watertube (Nebraska) }\end{array}$ & $10.9 \times 10^{3}$ & $\begin{array}{l}500 \\
\text { (40 wt.\% COM) }\end{array}$ & $\begin{array}{l}\text { Long-term tests were } \\
\text { completed; final char- } \\
\text { acterization tests were } \\
\text { conducted in } 1981 \text {. }\end{array}$ \\
\hline Interlake & $\begin{array}{l}\text { injection blast } \\
\text { furnace }\end{array}$ & $\begin{array}{l}1191 \text { tons of } \\
\text { metal per day }\end{array}$ & $\begin{array}{l}\text { short duration } \\
\text { test }\end{array}$ & $\begin{array}{l}\text { The blast furnace was shut } \\
\text { down because of a lack of } \\
\text { steel demand. }\end{array}$ \\
\hline \multicolumn{5}{|l|}{$\frac{\text { Privately supported }}{\text { Tests }}$} \\
\hline $\begin{array}{l}\text { Florida Power Co./ } \\
\text { DRAVo }\end{array}$ & $\begin{array}{l}\text { coal-designed } \\
\text { utility boiler (CE) }\end{array}$ & $1134 \times 10^{3}(383 \mathrm{MW})$ & $\begin{array}{l}33 \\
\text { ( } 45 \text { wt. } \% \text { COM) }\end{array}$ & The project was completed. \\
\hline $\begin{array}{l}\text { Florida Power \& } \\
\text { Light }\end{array}$ & $\begin{array}{l}\text { oil-designed } \\
\text { utility boiler (FW) }\end{array}$ & $1197.5 \times 10^{3}(400 \mathrm{MW})$ & $\begin{array}{l}\text { initiated in } \\
1980\end{array}$ & $\begin{array}{l}\text { Long-term operation of } \\
120 \text { days was conducted. }\end{array}$ \\
\hline
\end{tabular}


boiler. Slagging and fouling and fireside erosion of boiler. tubes depend strongly on coal-ash quantity and quality. It is therefore expected that the use of coal slurries in the replacement of fuel oil will require coal cleaning and that CWM will require removal of about three times as much ash as COM. It is possible that some low-ash coals with high ash-melting points may become usable as COM with minimum or no processing in oilfired boilers, while the preparation of CWM will almost certainly entail deep coal cleaning, probably below ash contents of $2 \%$.

\subsubsection{Research Recommendations}

As has been clearly indicated in Sec. 2.8.1, COM is ready for use in large-scale applications. To achieve improved efficiencies in the use of this fue 1 , additional fundamental research is desirable. Areas of uncertainty have been specified in Sec. 1.2E. Of these, the following merit emphasis:

- The stability and rheological properties of COM should be related to chemical composition.

- The atomization properties of COM should be better understood.

- Particulate and gas-pollutant emissions should be related quantitatively to COM composition and boiler design parameters.

- As in other coal-utilization technologies, ash formations, fouling and erosion require improved fundamental understanding. 


\section{9 .1 Overview}

Applications of coal-water mixtures (CWM) represent a relatively new area of coal utilization. The primary use is expected to involve CWM as replacement of oil in existing utility and industrial boilers. This fuel may also be used in gas turbines and in high-pressure gasification. Interest in CWM has increased recently, particularly in the U.S., Sweden, Canada, and Japan. ${ }^{1}$ Table 2.9-1 shows an FY1983 estimate of annual U.S. expenditures on $R \& D$ relating to coal-water mixtures; of the total $\sim \$ 26 \times 10^{6}$ R\&D budget in FY83, about $50 \%$ are DOE funds, while $40 \%$ represent commercial development of slurries. The remainder is supplied by utilities. Table 2.9-2 summarizes many of the currently active programs, some of which extend for more than one year. Not shown are proprietary efforts by industrial firms. Of the 15 studies shown, $\sim 6$ relate to combustion, 5 to slurry characteristics, 3 to atomization and droplet formation, and 4 to largescale applications and systems analysis.

Much of the R\&D on slurry formulation, coal-cleaning technology, and burner development is restricted by industrial developers. Researchers studying CWM combustion usually obtain data on slurry characterization from suppliers; independent CWM production may not produce commercially viable fuels. Most of the slurryproduction programs are supported by DOE or EPRI. The EPRI pro$\mathrm{gram}^{2}$ is focused in the following areas: (i) determining specifications and guidelines of CWM quality related to use in utility boilers; (ii) identifying and quantifying the effects of firing CWM in oil-designed boilers; (iii) developing supporting technology and demonstrating performance in boilers. Only a small part of the EPRI effort is devoted to supporting research on CWM combustion.

To date, no serious technical problems have been encountered in the use of CWM. However, work in this area is new and 
Tab1e 2.9-1. Estimated FY 1983 U.S. RGD expenditures on coal-water mixtures.

\begin{tabular}{|c|c|c|}
\hline Funding organization & $\begin{array}{l}\text { Annual estimated } \\
\text { budget in millions } \\
\text { of dollars }\end{array}$ & Areas selected for emphasis \\
\hline Eastern utilities (private) & 1 & beneficiation, combustion \\
\hline 11 companies (private) & 10 & commercial slurry development \\
\hline EPRI & 2 & $\begin{array}{l}\text { slurry specifications, boiler } \\
\text { demonstrations }\end{array}$ \\
\hline METC contracts (DOE) & 1 & supporting research \\
\hline METC indirect contracts (DOE) & 5 & $\begin{array}{l}\text { turbine-blade deposits, } \mathrm{NO}_{\mathrm{x}} \\
\text { formation, others }\end{array}$ \\
\hline METC in-house research (DOE) & 1.5 & gas-turbine applications \\
\hline PETC contracts (DOE) & 2 & $\begin{array}{l}\text { supporting research and demon- } \\
\text { stration }\end{array}$ \\
\hline PETC in-house research (DOE) & 3 & $\begin{array}{l}\text { slurry characteristics and } \\
\text { combustion }\end{array}$ \\
\hline Total & $\sim 26$ & \\
\hline
\end{tabular}


Table 2.9-2. Estimated identified 1983 CWM R\&D in the U.S.

\begin{tabular}{|c|c|c|c|}
\hline Organization & $\begin{array}{l}\text { Funding } \\
\text { source }\end{array}$ & $\begin{array}{c}\text { Total } \\
\text { project } \\
\text { budget in } \\
\text { millions } \\
\text { of dollars }\end{array}$ & Studies \\
\hline Adelphi & EPRI/private & $?$ & slurries \\
\hline AFR & PETC (DOE) & 0.2 & devolatilization \\
\hline$B \& W$ & EPRI (DOE) & $?^{-}$ & slurry specifications \\
\hline BYU & $\begin{array}{ll}\text { METC } & \text { (DOE) } \\
\text { PETC } & \text { (DOE) }\end{array}$ & $\begin{array}{l}0.15 \\
0.4\end{array}$ & $\begin{array}{l}\text { combustion } \\
\text { modeling }\end{array}$ \\
\hline Dupont & EPRI & 2.0 & $50 \mathrm{MW}_{\mathrm{e}}$ application \\
\hline $\mathrm{CE}$ & PETC (DOE) & 6.5 & $\begin{array}{l}\text { a broad program, including } \\
\text { large-scale applications }\end{array}$ \\
\hline CMU & PETC (DOE) & 0.6 & atomization, rheology \\
\hline EER & PETC (DOE) & $?$ & sulfur capture \\
\hline GE & METC & $?$ & turbine deposits \\
\hline MIT & $\begin{array}{r}\text { Private/PETC } \\
\text { (DOE) }\end{array}$ & 0.4 & pollutant production \\
\hline METC & DOE & 1.5 & $\begin{array}{l}\text { combustion processes in } \\
\text { gas turbines }\end{array}$ \\
\hline PETC & DOE & 3.0 & $\begin{array}{l}\text { slurry characteristics, } \\
\text { combustion }\end{array}$ \\
\hline PCC & PETC (DOE) & 0.2 & droplet modeling \\
\hline TRW & PETC (DOE) & 2.5 & systems analysis \\
\hline In procurement & EPRI & $?$ & $400 \mathrm{MWe}$ application \\
\hline
\end{tabular}


involves small-scale operations. It will require several more years to establish an adequate data base to evaluate the potential of CWM.

2.9.1A CWM Preparation, Handling, and Production

Eleven industrial organizations are known to be developing CWM for commercial use. Six have developed methods and equipment (pilot plants) for the production of CWMs in the 75120 TPD capacity range. The presently available studies suggest that mixtures for boiler applications will contain about $70 \%$ coal and $30 \%$ water. Coal percentages for gas turbine applications may be lower. The blended coal particles generally cover a range from small to large sizes. It is customary to use small percentages (ca. $1 \%$ ) of additives for the control of viscosity and dispersion. Claims are made that mixtures are stable for significant periods of time (e.g., one month). Independent research $^{3}$ is also being conducted on rheological properties of CWM.

The total 1983 on-stream capacity for the preparation of CWM is estimated by EPRI to be about 40,000 TPY of slurry (see Fig. 2.9.-1). More than a ten-fold increase in capacity will be required to conduct an extended demonstration in a utility boiler. This capacity will not be reached before 1985 .

\subsubsection{B Atomization and Dispersion}

Extensive research has not been performed on atomization rates of water in dispersions of coal in CWM. For example, only one paper on this subject (from BNL) was presented at the 4 th International Symposium on Coal Slurry Combustion and this discussion referred to coal-loading levels well below practically achievable levels. Atomization studies and the associated CWM nozzle designs have been considered by workers at PETC and ARC. Commercially available nozzles have frequently been used in early combustion studies. DOE/PETC has recently initiated sponsored research in this area. The efficiencies of coal burnout, fouling, and $\mathrm{NO}_{x}$ pollutant formation are related to droplet atomization and particle dispersion. 


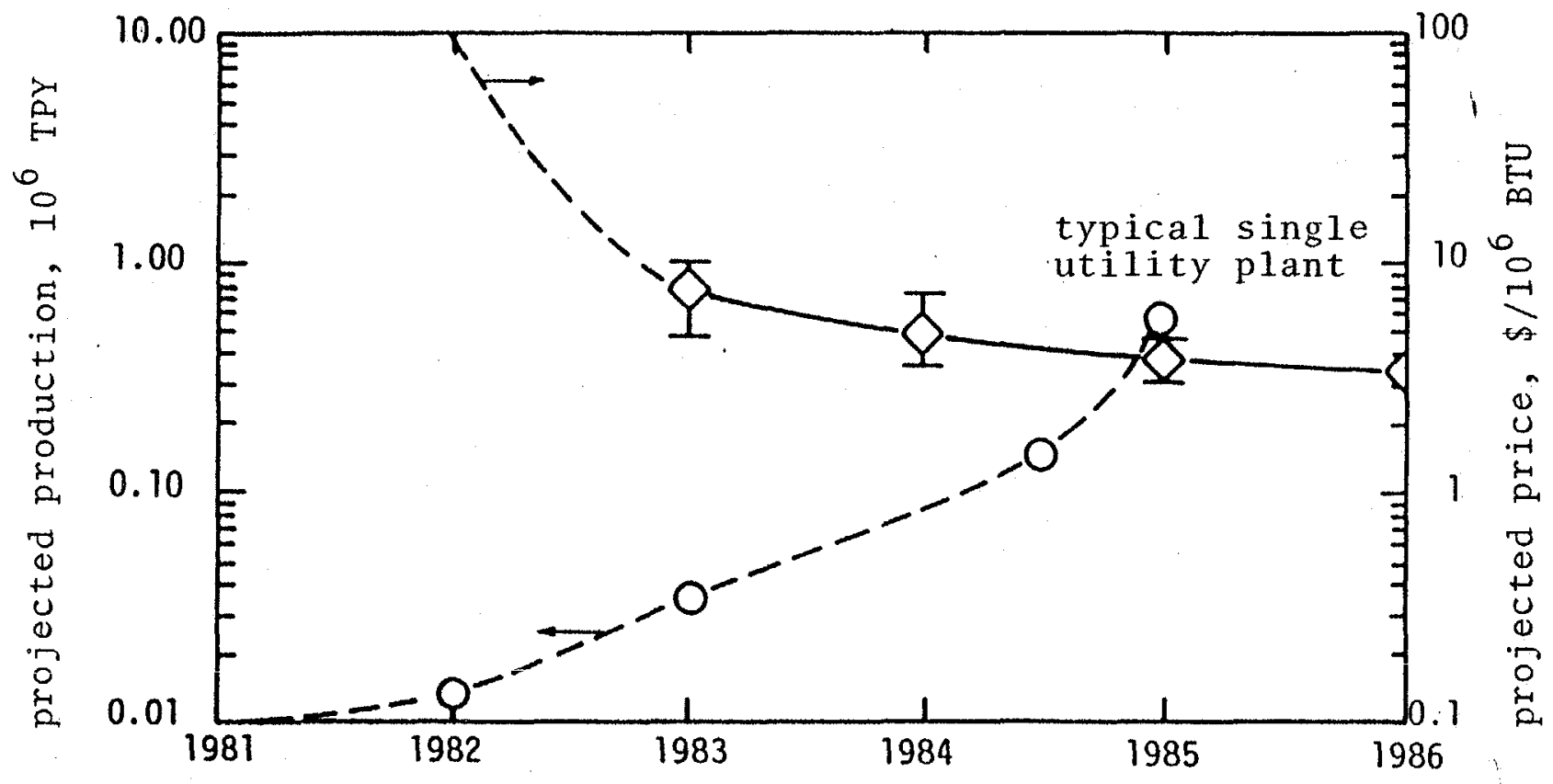

Fig. 2.9-1. EPRI projections of production rate and cost of CWM. ${ }^{2}$ 


\subsubsection{CWM Combustion and Pollutant Formation}

Early investigations of the combustion characteristics of pulverized CWMs were performed at ARC, ${ }^{4}$, PETC, ${ }^{5}$ and EPRI/B\&W. ${ }^{6}$ It is apparent from these studies that pulverized coal can be burned with high percentages of water, Coal burnout levels up to $98 \%$ were reported and CWMs containing up to $70 \%$ of coal were tested. PETC tests were conducted in $100 \mathrm{hp}$ and $700 \mathrm{hp}$ water tube boilers with up to $63 \%$ coal in the CWM. In the smaller unit, carbon conversion up to $85 \%$ was achieved while, in the larger unit, carbon conversion up to $96 \%$ was obtained with the use of surplus secondary air.

The $\mathrm{ARC}^{4}$ investigations on $\mathrm{CWM}$ involved coal percentages up to $65 \%$ in a small laboratory furnace $\left(10^{6} \mathrm{BTU} / \mathrm{hr}\right)$. Carbon conversion levels up to $90 \%$ were reported. More recent tests ${ }^{7}$ have shown combustion efficiencies up to $95 \%$ with $70 \%$ CWM in the sma11-scale furnace.

Investigations of CWM combustion are also underway at $\mathrm{BYU}^{7}$ and MIT. ${ }^{8}$ These studies provide details concerning flame structure. Burnout leve1s of over $99 \%$ for coal in $70 \%$ CWM have been reported by both laboratories. Figure 2.9-2 shows a compilation of recent1y reported data. It is clear that high burnout of coal in CWM is achievable, even though agglomeration of particles has been observed in SEM photographs of residual solids. Plans for larger scale testing of CWM in industrial and utility boilers have been outlined by workers at EPRI and DOE/PETC/CE.

\subsubsection{Research Recommendations}

Coal-water mixtures represent a new developing technology that has attracted significant national and international interest. RGD are proceeding at a significant level with balanced programs that include industrial- and utility-scale testing. U.S. DOE involvement has been significant and should be continued. 


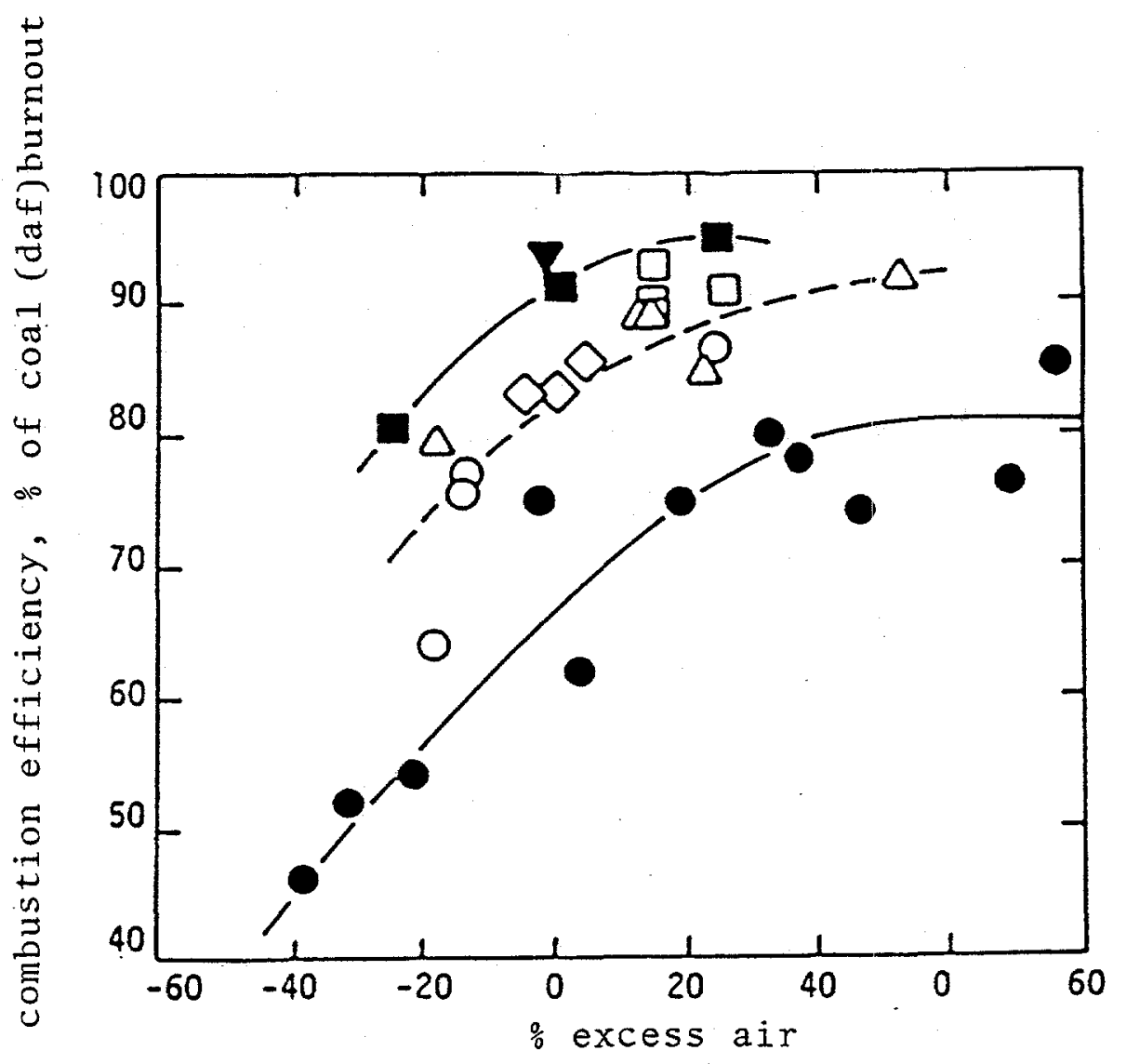

Fig. 2.9-2 Carbon conversion data for CWM. Legend:

- BYU Combustion Laboratory 0.5 MMBTU (with swir1) (1983); - BYU Combustion Laboratory 0.5 MMBTU (no swir1)(1983); $\square$ Fathering (1982), 4 MMBTU; $\nabla$ Pan et a1 (1982), 25 MMBTU; $\nabla$ pan et al (1982), 5 MMBTU; $\triangle 0$ McHale el al (1982), 1 MMBTU (with swirl); - McHale et al (1982), 1 MMBU (no swir1). 
We offer the following recommendations:

- DOE should participate in establishing a CWM data base regardless of world oil prices.

- DOE should establish strong combustion-research programs in non-DOE organizations.

- DOE should promote interchange of information among research, development and demonstration programs.

- DOE should continue the support of research in CWM after early full-scale demonstration tests have been successfully completed in order to allow optimization and improvements of early designs,

- Topics for research emphasis with DOE support include but should not be limited to the following: CWM properties (including effects of additives), mixture stabilities and aging, burner-design and its application for various particlesize distributions and formations; pollutant formation; slagging and fouling; process modeling; the effects of coal beneficiation and fine grinding (micronization).

In the areas of preparation and handing, fundamental studies should be performed on (a) optimization of CWM, including definitions of particle-size distributions for particulate coal loadings, the optimum use of additives, and the resulting mixture stabilities and useful life and (b) incorporation of physically or chemically beneficiated coals [e.g., produced by fine grinding (micronization)] to achieve reductions in ash levels to $\approx 3 \%$. 
In the areas of atomization and dispersion, studies should be performed (a) to determine the effects of variables such as mass-flow rates, pressure levels, and nozzle configurations that control the droplet-size distributions and the droplet and dustparticle dispersions for the ranges of solids loadings, coal sizes and distributions, and additives that are of practical interest and (b) to determine the relations between nozzle designs, secondary air-flow patterns, and mixing rates to achieve optimized burner designs and control coal agglomeration.

In the areas of combustion and pollutant production, the following studies should be performed: (a) Measurements are needed of combustion rates, fouling, and pollutant-formation characteristics of CWMs, including optimum coal solids levels, use of beneficiated coals with low ash contents, and effects of additives. Of particular importance are achievement of adequate flame stability, control of nozzle erosion, and high carbon conversion ( $>99 \%$ ), as well as control of ash and $\mathrm{NO}_{x}$ levels. (b) Designs of optimum burner configurations for $\mathrm{CWM}$ and correlations with slurry rheology remain to be accomplished. (c) Demonstration of successful, longterm operation of CWMs in large-scale, oil-designed utility boilers, with emphasis on slurry mixture stability, flame stability, control of fouling, ash and nozzle erosion, high carbon conversion, minimal boiler derating, and control of $\mathrm{NO}_{\mathrm{x}}$ levels. This applied task must be performed successfully before widespread commercial applications can occur. (d) Unresolved fundamental questions include the behavior of dispersions of condensed phases in turbulent media, droplet formation and evaporation in threephase flows, devolatilization processes of wet coals, and turbulence in swirling multiphase flows. 


\section{REFERENCES}

1. 4th International Symposium on Coal Slurry Combustion, May 10-12, 1982, Or1ando, F1orida.

2. K. E. Yeager and R. K. Manfred, "Coal Water Mixtures: Issues and Opportunities for the Electric Utility Industry," paper presented at the 10th Energy Technology Conference, Washington, D.C., February 28-March 2, 1983.

3. J. H. Eckmann, "Transport and Handling Characteristics of Coal Water Mixtures," in Ref. 1.

4. E. T. McHale, R. S. Scheffee, and N. P. Rossmeissel, Combustion and Flame 45, 121 (1982).

5. Y. S. Pan et al, "Exploratory Coal-Water and Coal-Methanol Mixture Tests in Oil-Designed Boilers," in Ref. 1.

6. G. A. Farthing, Jr., S. A. Johnson, and S. J. Vecci, "Combus tion Tests of Coal-Water Slurry," CS-2286, EPRI Final Report, Palo Alto, CA (March 1982).

7. G. J. Germane, L. D. Smoot, S. R. Dieh1, K. H. Richardson, and D. C. Rawlins, "Coal-Water Mixture Laboratory Combustion Studies," 5th Symposium on Coal Slurries, Florida (April 1983).

8. J. M. Beér, W. F. Farmayan, A. K. Gupta, and J. D. Teare, "The Combustion Heat Transfer, Ash Deposition and Pollutant Emission Characteristics of Concentrated Coa1-Water Slurries," MIT Report, Cambridge, Mass. (January 1983). 
2.10 Status and Needs for Mathematical Modeling of Coal-Combustion Processes

\subsection{0 .1 Overview}

Computer models of complex physical and chemical processes have played a vital role in the development of many major engineering products and developments. However, these models have not yet contributed to the improvement and control of coal-utilization processes. The complexity of the physical and chemical phenomena occurring during coal combustion, the lack of basic data, past limitations on computer power and speed, and the absence of careful diagnostic measurements on pilot and demonstration plants have been responsible for failure to connect modeling with practical experience. Current developments and advances may, however, change this status in the near future.

\subsubsection{A Potential Applications}

Potential applications of modeling range from applications that only require computation of general process features to those that require quantitative determinations of specific parameters. Representative uses are the following: (a) identification of general combustor features (e.g., carbon burn-up); (b) interpretation of measurements relating to process control; (c) identification of important test variables; (d) identification and measurements of rate-controlling processes; (e) definition of problem areas requiring additional investigations; ( $f$ ) use of modeling in scale-up; and $(\mathrm{g})$ use of modeling in design optimization. Representative measurements that should be encompassed by combustion models are the following: (a) design of a framework to assist in evaluation of the effects of coal quality and coal beneficiation on furnace operation; (b) estimation of particle trajectories to facilitate analysis and control of ash-deposit processes; (c) design and testing of burner developments to reduce $\mathrm{NO}_{X}$ emissions. 
The critical problem areas that should be addressed must include model reliability for predictions and costs of modeling in view of potential operational gains.

\subsubsection{B Classification of Process Models}

Comprehensive coal reaction models may be classified in the manner shown in Table 2.10-1, which also illustrates relations among the systems. Thus, a fluidized bed combustor may perhaps be approximated by a (zero-dimensional) perfectly-stirred reactor. An entrained-flow gasifier may be approximated as an ideal plug-flow reactor with solid-phase kinetics and heat transfer controlling the combustion rates. As an ambitious but not unreasonable goal, we propose the development of a two-dimensional, timedependent code to encompass coal-combustion processes.

We sha11 now elaborate on coal combustion models for (a) pulverized, entrained systems, (b) fluidized-bed reactors, and (c) moving or fixed-bed combustors.

\subsubsection{Basic Model Elements and Premises}

A model is a computerized code, which combines several model components (or submodels) and can be applied to the description of coal-combustion processes. The components that are often used in coal-combustion models include the following processes: turbulent fluid mechanics, gaseous turbulent combustion, particulate dispersion, particle interactions, coal devolatilization, heterogeneous char reactions, radiant heat transfer, pollutant formations, ash and slag formations, and other phenomena. These elements are illustrated for a pulverized coal flame in Fig. 2.10-1. The required elements differ somewhat for fluidized and fixed-bed systems. 
Table 2.10-1 A classification system for coal models.

\begin{tabular}{|c|c|c|c|}
\hline Reactor flow type & $\begin{array}{c}\text { Leve1 of } \\
\text { mathematical } \\
\text { complexity }\end{array}$ & Process applications & Process features \\
\hline $\begin{array}{l}\text { perfect } 1 y \text { stirred } \\
\text { reactor } 1,2\end{array}$ & $\begin{array}{l}\text { zero-dimensional } \\
\text { f1ow }\end{array}$ & fluidized bed & $\begin{array}{l}\text { we11-mixed, kinetical1y } \\
\text { controlied }\end{array}$ \\
\hline plug-flow reactor $3-5$ & $\begin{array}{l}\text { steady, one- } \\
\text { dimensional flow }\end{array}$ & $\begin{array}{l}\text { fixed beds } \\
\text { pulverized coal furnace } \\
\text { entrained gasifier } \\
\text { shale retort }\end{array}$ & $\begin{array}{l}\text { the extent of mixing is } \\
\text { specified and the pro- } \\
\text { cess is controlled by } \\
\text { solid reactions and heat } \\
\text { transfer }\end{array}$ \\
\hline see $\operatorname{Refs} \cdot 6,7$ & $\begin{array}{l}\text { transient, one- } \\
\text { dimensional flow }\end{array}$ & $\begin{array}{l}\text { coal mine explosions } \\
\text { coal process explosions } \\
\text { flame ignition and } \\
\text { stability }\end{array}$ & $\begin{array}{l}\text { pre-mixed flame with } \\
\text { kinetic and diffusion } \\
\text { control }\end{array}$ \\
\hline recirculating $f 1$ ow 8,9 & $\begin{array}{l}\text { steady or tran- } \\
\text { sient, multi- } \\
\text { dimensional flow }\end{array}$ & $\begin{array}{l}\text { power generators } \\
\text { entrained gasifiers } \\
\text { industrial furnaces }\end{array}$ & $\begin{array}{l}\text { diffusion flames with } \\
\text { kinetic control by mix- } \\
\text { ing, gas kinetics, and } \\
\text { solid-phase reactions }\end{array}$ \\
\hline
\end{tabular}


10 combustion

products/pollutants

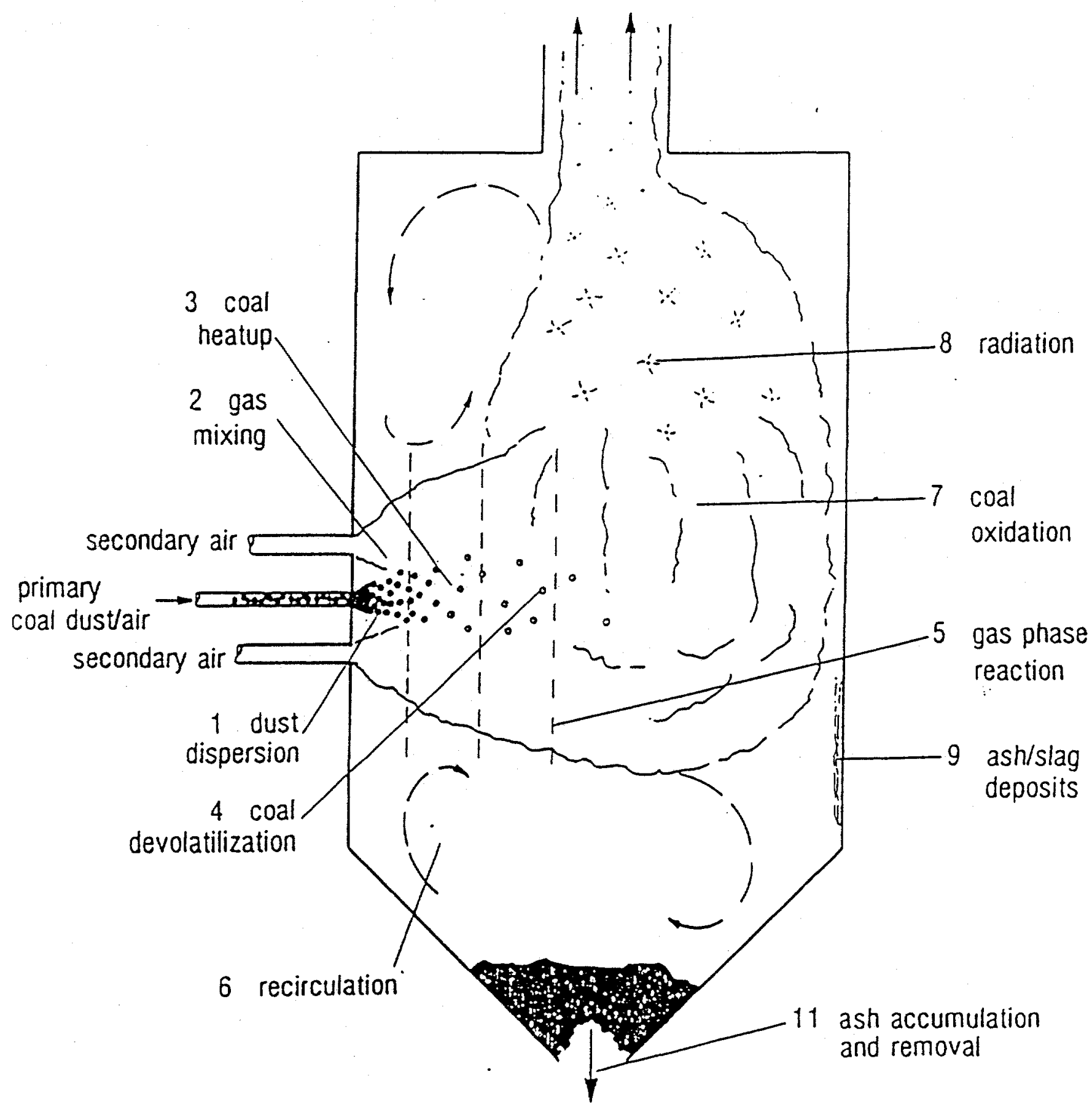

Fig. 2.10-1 Aspects of a pulverized coal combustor. 
Key premises that provide the foundation for the development of combustion models include the following: (a) The behavior of clusters or clouds of particles can be predicted from information on the behavior of individual particles or small groups of particles. (b) Unsteady or quasi-steady behavior can be predicted from basic data obtained from steady-state measurements. (c) Some of the complex processes occurring in coal combustion may often be approximated by rate-controlling steps. (d) Applications of numerical methods that have been evaluated for simple systems will produce acceptably accurate results in more complex systems. Since the validity of the specified premises cannot always be demonstrated directly, model validation for complex processes must ultimately be done empirically. In many published studies, fundamental aspects of the coal-combustion process are emphasized, viz. coal pore diffusion, radiative properties of coals and chars, coal structure and its relation to reactions, and particle changes during devolatilization. Nevertheless, the development of coal-process models still requires a large number of assumptions, which may not always be supported by experimental data. Thus, demonstration of validity and accuracy of model predictions is a continuing challenge. The codes are often too extensive to permit separate and complete evaluation of every component. Comparisons with gross data such as outlet temperature or composition provides little confidence that the entire model is valid. Comparisons with mean and time-varying values of spatially-resolved properties generally constitute much stronger tests.

A code includes input properties, independent and dependent variables, and model parameters. Among the independent variables are the physical coordinates $(x, y, z)$ and the time $(t)$. Dependent variables include gas species compositions, temperatures, and velocities; pressure, mean turbulent kinetic energy, mixture fractions (means and variances), bulk densities, particle temperatures and velocities, turbulent energy dissipation, particle-size distribution, elemental composition, extent of reaction, radiant heat flux. Input data for each inlet stream include gas velocities, 
compositions, temperatures, turbulent intensities, mass-f1ow rates, and pressures; elemental fuel composition, particle temperatures, size distributions, velocities, mass-flow rates, and bulk densities. Reactor parameters include the combustor configurations, inlet configurations, inlet locations, dimensions, wall materials, and thicknesses.

Important physical parameters for the model subcomponents must also be specified. These parameters are obtained primarily from laboratory measurements. Determinations must be made of the sensitivity of code predictions to these parameters. Approximately 30 physical input parameters are required for the twodimensional pulverized coal model of smoot et al. 8 Coefficients occurring in the submodel components describe turbulence, gaseous combustion, particle and droplet dispersion, coal reaction, and radiative and convective heat transfer. Numerical (i.e., grid spacing) and input parameters (i.e., turbulent intensity) must be specified. These parameters are coefficients and constants for a heuristic description of various physical processes. They are usually obtained by comparison of code model predictions with laboratory measurements. Few are established with certainty.

\subsubsection{Coal-Combustion Modeling}

Attempts to calculate the detailed performance of turbulent, pulverized coal reaction processes have been made during the last decade. Prior to 1970 , computations were based on overall global calculations and often involved only a radiation submodel. Details of the mixing processes were not quantified.

Modeling of turbulent reaction processes is still under development. 10,11 At least 14 pulverized coal-conversion models has been developed since 1970 and were recently reviewed in Ref. 12 . Three codes involve the use of the perfectly-stirred reactor approach in combination with plug flow, five are one-dimensional, and 
six are multi-dimensional codes. Eight of the models were applied specifically to entrained-flow gasification.

The foundations of the most advanced pulverized coal-combustion models are adequate for some areas of application. Several unresolved fundamental issues remain. Paramount among these are interactions of turbulence with chemical reactions and dispersion in multi-phase media. Evaluations of these codes have been limited.

Codes for fixed, moving, and fluidized-bed combustors have also been developed to some extent. ${ }^{12}$

\subsubsection{E Model Evaluation}

Coal models are evaluated by comparisons with test data. Stack data (e.g., carbon conversion at the combustor exit) yield little confidence of model validity, while comparisons with detailed profile data inside a combustor may provide significant sensitivity tests. Detailed measurements for code evaluation may be performed on non-reacting gaseous systems, non-reacting particle-laden systems, gaseous combustion processes, coal combustion, coal gasification, and coal-water-mixture combustion. These include both simple and complex flows. Although some data are available, there is a continuing need for carefully measured and well-documented profile data for code evaluations, which may include many parameters and detailed measurements on reactor configuration, dimensions, inlet stream conditions (compositions, turbulence intensities, temperatures), and combustor operating conditions.

Additional work is also needed on laboratory measurements, theoretical developments, and comparisons of predictions on subcomponents of coal codes with data. As the description of elementary phenomena is improved, new results and more accurate coefficients should be incorporated into the process models. 


\subsubsection{F Current Modeling Effort}

The current level of effort on the development of coalcombustion codes is relatively low. Table 2.10-2 summarizes known U.S. modeling research on pulverized coal systems. Total U.S. expenditures in this area are probably less than $\$ 1 \times 10^{6} / \mathrm{yr}$. Work on other models appears to represent a still lower level of effort.

\subsubsection{Research Recommendations}

We recommend that the DOE program include each of the following:

- An organized program of development of coal-combustion models should be maintained. Development should include both entrained and fluidized beds. Model work on gasification, liquefaction and combustion should be coordinated.

- Increased near-term emphasis should be directed toward model evaluation in applications, using properly measured parameters as indicators.

- There should be continued support for the development and improvement of sub-models. Augmented basic work in such areas as turbulent reacting flows, especially in multiphase systems, is well justified.

It may be useful to coordinate code comparisons and to facilitate the storing, maintenance and distribution of codes. 
Table 2.10-2 Examples of current U.S. modeling on pulverized coal combustion.

\begin{tabular}{|c|c|c|}
\hline Organization & $\begin{array}{l}\text { Source of } \\
\text { Funds } \\
\end{array}$ & Direction \\
\hline Babcock and Wilcox & PETC (DOE) & $\begin{array}{l}\text { extend and adapt general } \\
\text { codes }\end{array}$ \\
\hline $\begin{array}{l}\text { Brigham Young } \\
\text { University }\end{array}$ & $\begin{array}{l}\text { EPRI / METC(DOE) } \\
\text { PETC (DOE) }\end{array}$ & $\begin{array}{l}\text { a two-dimensional general } \\
\text { code evaluation and exten- } \\
\text { sion to three dimensions }\end{array}$ \\
\hline EER & PETC (DOE) & \\
\hline $\begin{array}{l}\text { Los Alamos National } \\
\text { Laboratory }\end{array}$ & EPRI & $\begin{array}{l}\text { evaluation of the } \mathrm{S}^{3} \text { code } \\
\text { for coal gasification }\end{array}$ \\
\hline METC & METC (DOE) & $\begin{array}{l}\text { evaluation of the } \mathrm{s}^{3} \text { and } \\
\text { BYU codes }\end{array}$ \\
\hline $\begin{array}{l}\text { Estimated total annual } \\
\text { expenditures }\end{array}$ & $\$ 0.5$ & $1.0 \times 10^{6}$ \\
\hline
\end{tabular}




\section{REFERENCES}

1. L. S, Caretto, "Modeling Fluidized Bed Combustion," Western States Section, The Combustion Institute, Fall Meeting, Stanford University, Palo Alto, CA, Oct. 17-18, 1977.

2. J. M. Beêr, "The Fluidized Combustion of Coal," 16th Symposium (International) on Combustion, pp. 439-460, The Combustion Institute, Pittsburgh, PA (1977).

3. P. J. Smith, and L. D. Smoot, "One-Dimensional Model for Pu1verized Coal Combustion and Gasification," Combust. Sci. Tech. $23,17-31(1980)$.

4. A. M. Winslow, "Numerical Model of Coal Gasification in a Packed Bed," 16th Symposium (International) on Combustion, pp. 503-514, The Combustion Institute, Pittsburgh, PA (1977).

5. J. H. George and H. G. Harris, "Mathematical Modeling of Oil Shale Retorting," DOE/LETC-1781-15/1, University of Wyoming, Laramie, WY (1979).

6. L. D. Smoot, M. D. Horton, and G. A. Williams, "Propagation of Laminar Pulverized Coal-Air Flames," 16th Symposium (Internationa1) on Combustion, pp. 375-387, The Combustion Institute, Pittsburgh, PA (1977).

7. J. C. Krazinski, R. 0. Buckins, and H. Krier, "Coal Dust Flames: A Review and Development of a Model of Flame Propagation," Progr. Energy Comb. Sci. 5, 31-71 (1979).

8. P. J. Smith, T. H. Fletcher, and L. D. Smoot, "Model for Pulverized Coal-Fired Reactors," 18th Symposium (International) on Combustion, pp. 1285-1293, The Combustion Institute, Pittsburgh, PA (1981).

9. F. C. Lockwood, A. P. Salooja, and S. A. Syed, "A Prediction Method for Coal-Fired Furnaces," Comb. Flame 38, 1-15 (1980).

10. D. G. Lilley, "Flow Field Modeling in Practical Combustors: A Review," J. Energy 3, 193-210 (1979).

11. F. A. Williams and P. A. Libby, "Some Implications of Recent Theoretical Studies in Turbulent Combustion," AIAA Paper 800012, Eighteenth Aerospace Sciences Meeting, New York, NY (1980).

12. L. D. Smoot, "Pulverized Coal Diffusion Flames: A Perspective Through Modeling," 18th Symposium (International) on Combustion, pp. 1185-1202, The Combustion Institute, Pittsburgh, PA (1981). 


\subsection{Environmental Issues}

Present and anticipated costs of maintaining and improving environmental quality are important factors in expanding U.S. utilization of coal as an energy source. A new, coal-fired utility power plant, designed to comply with environmental regulations in effect in 1980 , would have required up to $35 \%$ of total capital cost allocation for environmental control systems. Assuming reasonable advances in control technology, a plant designed to meet 1985 standards is anticipated to have up to $45 \%$ of capital cost and $35 \%$ of operating cost attributable to environmental controls.

\subsection{1 .1 Overview}

Important environmental issues must be addressed in nearterm and long-term planning relating to coal combustion research. These are identified briefly in the following statements. (i). Growing concern about atmospheric loadings of sulfur and nitrogen oxides has been responsible for increasing emphasis on retrofittable technologies to effect $\mathrm{SO}_{2}$ and $\mathrm{NO}_{\mathrm{x}}$ reductions in existing coal-combustion installations. (ii). Current discussions relating to atmospheric visibility, inhaled particles, and airborne trace elements indicate that control of fine particulate matter has become an important research issue. (iii). The emergence of the toxic torts concept of environmental law has served to augment the care and level of effort that are dedicated to identification and control of potentially toxic substances in air, water, and solid effluent streams.

(iv). The economic incentive to convert existing, large, oil-fired combustion facilities to coal firing has increased the priority assigned to research and development relating to improved, costeffective, retrofittable, environmental controls, particularly those usable in space-constrained sites. ( $v$ ). New coal-fired powergeneration capacity is often needed most urgently in areas where available water supplies are fully committed for purposes other than 
cooling and consumptive use. This is especially the case Sun Belt, where future electricity-demand projections are higher than average because of anticipated large population growths. These identified issues are currently important and may require resolution by the year 1990 or sooner. The following research recommendations deal with these problems, as well as with fundamental research that may lead to important advances in the future.

\subsubsection{Research Recommendations}

In the areas of coal chemistry, needed research includes the following:

- Coal cleaning - Thorough knowledge of coal composition should facilitate the optimum design of coal-cleaning systems. As yet, there are no documented quantitative relations between coal composition and the resulting effects on coal-cleaning efficiency and costs. The types of coalcleaning design features that are dictated by composition variables in coals remain to be identified.

- Elemental balance - The fates of the chemical constituents of coal during coal transport, coal preparation and cleaning, combustion, and postcombustion clean-up processes are poorly documented. We have incomplete knowledge of the many physical and chemical processes involved and there are few available credible data. Rational planning of environmental control strategies would be enhanced if dependable information were available on detailed reaction processes involving chemical species in coals as functions of feedcoal composition, combustion conditions and other process variables

- Emissions production - There is inadequate understanding of the effects of coal compositions and combustion-process variables on emission loadings and compositions. Thus, 
better-documented understanding of the following phenomena might well improve the design and cost of environmental control systems: (i) fly ash/bottom ash split; (ii) composition, size distribution and resistivity of fly ash for removal by precipitation or fabric filtration, and for disposal or utilization; (iii) composition of bottom ash for disposal or utilization; (iv) concentrations and speciations of nitrogen oxides; $(v)$ concentrations and speciations of sulfur oxides.

In combustion chemistry, research emphasis should include at least two important topics in order to improve control technologies:

- $\mathrm{NO}_{\mathrm{x}}$ chemistry - There is need for more knowledge of the fundamental reaction chemistry involving nitrogen, both within and following the furnace combustion zone. Larger scale tests should be performed to anchor and supplement bench-scale and prototype test programs being carried out by boiler manufacturers, EPRI, and others.

- Additives chemistry - Fundamental studies in reaction kinetics may prove to be useful in the successful development and reliable utilization of combustion additives to enhance electrostatic precipitation of fly ash and capture sulfur oxides as they are formed in the furnace.

Gas cleaning techniques will have to be developed for pressurized combustors and improved sulfur cleaning procedures are needed.

- Pressurized combustors - The successful development of advanced coal-utilization options, notably $\mathrm{PFBC}$, will require effective, hot-gas, particulate cleanup hardware. The preferred approaches among a number of current developments (e.g., high-performance cyclones, ceramic filters, hightemperature electrostatics removal systems, moving bed 
granular filters) remain to be identified.

- $\mathrm{SO}_{2}$ scrubber chemistry - Many of the reliability problems experienced by operators of coal-fired, flue-gas desulfurization (FGD), alkali scrubbing systems stem from inadequate understanding of the complex process chemistry. In 19791980, DOE, in consultation with EPRI, undertook a comprehensive investigation of this problem at the Morgantown Energy Technology Center, which was phased out, because of. lack of funding, soon after inception. Many of the applied aspects of the intended program were taken up by EPRI. However, there is need for a substantial, long-term, fundamental effort to support future new and retrofit alkali FGD systems.

Special problems are also associated with studies in biochemistry.

- Toxic hazards - The toxic potential of natural and artificial chemical species produced during coal utilization requires a long-term, stable program on toxic substance identification and toxic hazard evaluation, including research on coal constituents and coal-combustion byproducts in gaseous, liquid, and solid effluent streams.

In conclusion, it is worth emphasizing that all of the specified programs will be facilitated by the development of new or improved diagnostic procedures.

- Instrumentation - Advances in analytical techniques and electronics technology have permitted the determination of trace constituents and have also led to improved accuracy in the measurements of many environmentally important materials encountered in coal-combustion. facilities. However, these technical advances have not often been extended successfully 
to the severe service environments found at the facilities. Thus, there is need for the development of more robust, high-reliability process control and monitoring instruments and systems for coal-combustion applications at plant sites. 


\section{$2.12 \quad$ Utility Perspectives}

\subsection{2 .1 Overview}

Electric utility research in the United States is sponsored by three major groups. (a) Utilities carry out research either directly or in cooperation with EPRI. Individual utility research reflects the specific needs of the local service territory or system configuration. (b) Manufacturers of electrical equipment and other utility suppliers conduct R\&D programs that are generally directed at product development or improvement, but they may also be involved with research on broader concepts. (c) Federal government R\&D funding useful to the utility industry has traditionally been longer range and more risky in nature.

\subsubsection{A Research Criteria}

Five criteria can be used to judge the effectiveness of electric utility R\&D in meeting the needs of utilities and their customers. These are enumerated below.

(i) Minimization of the need for capital acquisition and revenue requirements - The cost of electricity and ability of utilities to finance necessary investments are significant concerns. Highest priority is placed on achieving more effective, less costly operation and better availability of existing and planned facilities while extending the life of existing generating units, transmission facilities, and distribution systems.

(ii) Preservation of fuel availability - Reducing national dependence on foreign oil is important. Because electricity can be produced from plentiful domestic fuels, especially coal and uranium, and can be used to power many end-use needs cost-effectively, it can be an important factor in achieving this national 
goal. Utility R\&D emphasizes clean, cost-effective production of electricity from plentiful domestic resources and productive use of electricity.

(iii) Meeting health, safety, and environmental requirements - Near-term RqD stresses better understanding of the health, safety and environmental effects of air and water effluents, electric fields, and solid wastes. Developing cost-effective, reliable control technologies is also an important objective.

(iv) Achievement of greater conservation and productivity in energy consumption - Improving national economic productivity is critically important to the United States: Electricity can play a key role in achieving this goal. The utility industry will be a major participant in R\&D directed at improving energy end-use efficiency and overall productivity.

(v) Improvement of utility system flexibility - Utilities must be able to cope with a high degree of uncertainty while making decisions affecting their own and their customers' future. Utility R\&D focuses on analytic and technological developments that will provide utility management with sufficient flexibility to deal with a wide range of uncertain future events.

\subsubsection{B EPRI Research Strategy}

The main points of EPRI research strategy can be discussed in terms of six major areas of utility interest.

(i) Energy analysis - EPRI research must provide information and tools to help utilities plan and manage uncertainty. The Institute's program must develop a greater understanding of the role of electricity in the economy and provide tools to permit selection and evaluation of R\&D options. 
(ii) Environment - EPRI is dedicated to provide sound scientific data derived from independent, peer-reviewed research on topics of current environmental concern to help utilities and others in the regulatory process. Current environmental control capability will be improved by reducing capital and operating costs and preserving or improving overall plant availability. EPRI will explore the effects of new technologies and will be alert to emerging environmental issues.

(iii) Fue1s - With the outlook for fuel availability and price uncertainty, EPRI research must concentrate on the abundant domestic fuels. The extent of coal use must be increased and the utilization of nuclear fuels extended. Technologies that will permit coal to be substituted for oil and natural gas must be developed. EPRI will participate on a limited basis in the development of synthetic or other alternative liquid or gaseous fuels for utility use.

(iv) Generation - Since economic problems facing the nation and the utility industry appear to be the most pressing near-term issues, EPRI must emphasize research related to the productivity of the investment in existing or new conventional plants. For the future, EPRI must foster clean, cost-effective, advanced coal-fired plant technologies, development of modular, quickly sited generation technologies, and participate in the development of advanced nuclear and renewable concepts.

(v) Delivery - The same economic pressures also force maximization of the use of existing transmission and distribution facilities. Research must be concentrated on reducing system and equipment losses, reducing equipment and operating costs, improving reliability, extending the life of existing equipment and systems, and improving loading practices. For the future, the Institute must provide technologies for interconnection and operation of large, more complex systems and foster development of new technologies to move electricity over longer distances and deliver it to customers more efficiently. 
(vi) Energy management and conservation - Over the next several decades, substantial changes in energy use technology will be needed to increase overall productivity in industry and business and to maintain comfort and convenience at home. EPRI research must support utility load and energy management efforts by serving as a clearing house for ideas and information and by augmenting individual utility programs. EPRI will promote productive new end-use energy technology research by participating in a limited fashion with electrical appliance and equipment suppliers and users to develop and market new concepts.

\subsection{2 .2 Research Recommendations}

One challenge resulting from the specified strategies and program plans is development of the equipment and techniques which help the nation weather its current economic difficulties without sacrificing opportunities which will be essential in the 1990 s and beyond. A strategy of balance, prudence and flexibility will best serve the nation in an era when uncertainties may continue to be great.

Some of the key objectives with respect to coal-combustionrelated technologies are the following:

- Provide improved characterization of domestic coal resources.

- Develop improved coal quality control and assessment technology.

- Improve the performance and longevity of conventional coal-fired installations through incipient failure analysis and diagnostic instrumentation, failure cause analyses, equipment design and operating guidelines for improved operation.

- Improve the cost and reliability of environmental control technologies through integrated emission control, particulate control, solid waste disposal and use, $\mathrm{SO}_{2}$ control, water quality control, $\mathrm{NO}_{\mathrm{x}}$ control, and heat ${ }^{2}$ rejection. 
- Develop clean, modular, quickly sited new coal-fired technology which will reduce the cost of energy utilization to both consumer and stockholder for the following systems: AFBC, integrated gasification - combined cycle, PFBC turbocharged boiler, advanced PC power plant, PFBC - combined cycle.

- Develop technology for conversion of petroleum capacity to coal through applications of coal slurries, microfine coal, and coal liquefaction.

\subsubsection{A Major Issues for the Utility Industry}

The utility industry suffers from inability to fund technology development through to first commercial operation.

There are generally inadequate research foundations for long range, high-risk technological opportunities.

National energy policy is driven by short-term oil availability and cost and not by long-term needs.

There are inadequate economic and regulatory incentives to insure rapid commercial application of new technological results.

Abrupt Federal policy changes are made without prior planning with the private sector and tend to confound the long-term needs of the utility industry.

The domestic equipment supply capability is rapidly eroding and is becoming increasingly vulnerable to foreign competition.

Current federal energy RED policy places primary responsibility for innovation and development on the private sector. The success of this policy depends on undefined economic and regulatory incentives to make technology development attractive to the private sector. Until these incentives are better defined for the economically fragile area of coal combustion R\&D, opportunities in coalquality improvement, fluidized bed and other coal combustion advances, as well as environmental control technologies,will continue to be constrainted from timely development and application. A11 of these technologies can have major impacts on the quantity and quality of coal utilization over the next 20 to 30 years. 
The issue becomes critical when it is necessary to build large-scale demonstrations. These are essential elements in proving out the economics and technical aspects of new technologies. It is often necessary to gain experience with several such large-scale projects before the risks are reduced to the level of broad commercial acceptability. EPRI and other private sector organizations are capable of participating in these efforts but are not capable of assuming sole responsibility for their sponsorship. This problem is further exacerbated by the current sluggish economic posture throughout the private sector.

Furthermore, difficulties in maintaining adequate emphasis on supporting research, for which government funding is also being reduced, pose a longer term threat to the technological base necessary for technical and commercial energy leadership.

- In view of the well identified position of the utility industry and its particular problems, we recommend that DOE RED strategy be developed with full recognition of utility problems, needs and capabilities and that program implementation be carefully coordinated with the primary utility research organization represented by EPRI. 
APPENDIX A

\section{STATEMENT OF WOPK}

UNIVERSITY OF CALIFORNIA, SAN DIEGO

(COAL COMBUSTION AMD APPLICATIONS WORKING GROUP)

The objective of this project is to provide a forum for university and industrial representatives to develop an independent assessment that will identify ionger term research needs associated with coal combustion and closely allied application technologies. The assessment shall include recommendations and prioritizations to DOE of research areas and topics that may be expected to contribute to improved economic and environmental performance for coal combustion and application techrologies.

The Contractor shall form a Coal Combustion and Applications Working Group ("the Working Group," or "CCAWG") consisting of the Principa? Investigator, a graduate student assistant, and consultants drawn from the academic and industrial communities with expertise in coal combustion and chemistry. With assistance as needed from the lorking Group, the Contractor shall prepare a project work plan for DoE review and approval including methodology for obtaining diversified views and independent assessments from both the academic and industrial commuities concerning coal combustion and application technologies, technical approaches for assessing research needs, and site visit requirements.

In accordance with the work plan, the Contractor will conduct necessary tasks as follows:

1. The Contractor shall make site visits to coal combustion and application projects to gain first-hand familiarity with currently available or developing utilization technologies, including details of operational program aspects. These site visits shall include, but not be limited to, the following types of coal utilization processes related to coal combustion:

- Pulverized Coal and Synfuels Combustion Fundamentals fevolatilization, pyrolysis, ignition, soot formation, flame stability, carbon burnout, slagging effects, stability of coal/water mixtures.) 
- Flue Gas Cleanup (Advanced Nox/SOx/particulate cleanup)

- Gas Stream Cleanup (turbine cleanup systems)

- Combustion Systems (atmospheric and pressurized fluidized bed combustion, advanced combustor concepts, utilization of alternative fuels such as coal/water mixtures)

- Heat Engines/Power Systems (high temperature turbines, turbine corrosion and cooling tests)

A particular effort will be made to assess environmental impacts of direct coal combustion in all its forms and to evaluate procedures currently available to industry and being explored by universities for mitigating adverse environmental éffects of coal use, including coal cleaning, coal combustion system modifications, and stack-gas clean-up.

2. The Contractor shall undertake other means to obtain information, including technical discussions with government, industrial, and academic specialists in coal combustion and application technology and review of relevant technical literature.

3. The.Contractor shail submit to the DOE Fossil Energy Program and the Office of Energy Research an interim letter report describing each site visit and significant technical meeting attended by members of the Working Group. The contractor shall also be available to attend a reasonabie number of project status meetings with DOE Headquarters officials in the Office of Energy Research and Fossil Energy Program.

4. Based on information obtained in Tasks 1 and 2, the Contractor shall prepare and furnish an assessment that addresses long-term research needs and issues directly related to coal combustion and its application technologies as indicated in Task 1 . The Contractor and the Working Group shall direct the assessment to those R\&D aspects that properiy fall within the purview of 
the government's R\&D responsibilities, specifically the longer-range, high-risk, and fundamental research activities in DOE that focus on acquiring the technology base necessary for industry to develop and demonstrate processes with minimal government involvement. It shall not be the responsibility of the Contractor or CCAWG to assess research needs appropriate to industrial development and demonstration activities.

A final report shall be prepared by the Contractor that summarizes the overall assessment of coal combustion research needs developed by CCAWG. The assessment shall include an identification and prioritization of research needs in those coal utilization areas stated in Section 1; above, and shall provide the rationale and justification for the specific research needs and their prioritization as considered in the context of the administration's Ren program policy. The prioritization shall group research needs in three broad areas that require early emphasis: critical; high; moderate priority.

The final report will also include the purpose and approach of the study, the relation of the research needs identified in the final report to the current role of government R\&D activities, a list of consultants involved in CCAWG, the sites and projects visited, and other information sources used by the Working Group. 